UNIVERZITET U BEOGRADU

MEDICINSKI FAKULTET

Mladenović T. Zorica

DIJAGNOSTIČKI I PROGNOSTIČKI ZNAČAJ PROCENE KORONARNE REZERVE PROTOKA ODREĐENE TRANSTORAKALNOM DOPPLER EHOKARDIOGRAFIJOM KOD BOLESNIKA SA URAĐENOM KORONARNOM ANGIOGRAFIJOM POMOĆU KOMPJUTERIZOVANE TOMOGRAFIJE

Doktorska disertacija

Beograd, 2012 


\section{UNIVERSITY OF BELGRADE}

MEDICAL FACULTY

Mladenovic T. Zorica

DIAGNOSTIC AND PROGNOSTIC VALUE OF CORONARY FLOW RESERVE DETERMINED BY TRANSTHORACIC DOPPLER ECHOCARDIOGRAPHY IN PATIENTS WITH PREVIOUSLY PERFORMED MULTI-SLICE COMPUTED TOMOGRAPHY

Doctoral Dissertation

Belgrade, 2012 


\section{Mentor:}

Doc.dr sci Ana Đorđević Dikić

Klinički centar Srbije, Klinika za Kardiologiju

Medicinski Fakultet, Univerzitet u Beogradu

\section{Komisija:}

Prof.dr sci Dragana Šobić Šaranović

Klinički centar Srbije, Institut za Nuklearnu medicinu

Medicinski Fakultet, Univerzitet u Beogradu

Doc.dr sci Branko Beleslin

Klinički centar Srbije, Klinika za Kardiologiju

Medicinski Fakultet, Univerzitet u Beogradu

Prof.dr sci Danica Matić

profesor u penziji

Medicinski Fakultet, Univerzitet u Beogradu

Datum odbrane: 


\section{Zahvalnica}

Docentkinji dr sci Ani Đorđević Dikić neizmerno hvala na beskrajnom strpljenju, dobronamernosti, nesebičnom pružanju znanja i velikom trudu uloženom u svaki trenutak sprovođenja ovog istraživanja, od početne ideje do samog kraja.

Profesoru dr sci Draganu Tavčiovskom zahvaljujem na poverenju s kojim je bodrio moje stručno usavršavanje, razumevanju i podršci koje su mi davale snagu da nastavim.

Zahvaljujem se kolegama dr Siniši Rusoviću i dr Miši Mihajloviću na uloženom vremenu i ličnoj angažovanosti u toku same izrade doktorske teze.

dr Zoranu Joviću, dr Predragu Đuriću i dr Borisu Džudoviću želim da izrazim zahvalnost na optimizmu i pomoći pri realizaciju samog rada.

Kolektivu Klinike za Kardiologiju, Vojno Medicinske Akademije u Beogradu na pomoći tokom realizacije ovog istraživanja.

Mojim roditeljima,

zbog požrtvovanosti i ljubavi kojom su olakšavali moj put 


\section{Dijagnostički i prognostički značaj procene koronarne rezerve protoka određene transtorakalnom Doppler ehokardiografijom kod bolesnika sa urađenom koronarnom angiografijom pomoću kompjuterizovane tomografije}

\section{Rezime:}

Cilj: Koronarna angiografija pomoću kompjuterizovane tomografije (MSCT) omogućava uvid u morfološke karakteristike koronarne okluzivne bolesti, ali sa otežanom preciznom kvantifikacijom aterosklerotskih lezija. Transtorakalna Doppler ehokardiografija (TTDE) procenjuje funkcionalni značaj aterosklerotskih lezija. Tokom studije smo pokušali da procenimo aditivni dijagnostički i prognostički značaj koronarne rezerve protoka (CFR) određene putem TTDE kod bolesnika sa prethodno detektovanim aterosklerotskim lezijama putem MSCT na prednje descedentoj arteriji (LAD) i desnoj koronaroj arteriji (RCA), koristeći invazivnu koronarografiju (IK) kao referenti metod.

Metode: Prospektivna studija je obuhvatila 84 bolesnika, u stabilnom kardijalnom statusu, sa prethodno verfikovanim koronarnim stenozama na LAD i/ili RCA putem MSCT. TTDE procena CFR-a sa adenozinom je izvršena na LAD ( $\mathrm{n}=75)$; RCA ( $\mathrm{n}=61)$, ukupno 136 arterija, IK je sprovedena kod svih bolesnika 24 do 48 sati posle TTDE-CFR-a.

Rezultati: Analiza Cochran Q testom je uočila statistički značajnu razliku između tehnika pri detekciji signifikantnih stenoza na LAD i RCA ( $<<0.01)$, analiza između pojedinačnih tehnika je pokazala značajnu razliku između MSCT-a i CFR-a (p<0.05), MSCT-a i IK (p<0.01), dok između CFR-a i IK nije detektovana značajna razlika ( $\mathrm{p}>0.05$ ). MSCT je imala senzitivnost za LAD:88.00\%; RCA:86.21, specifičnost LAD:57.63\%; RCA:69.10\%, pozitivna LAD:46.81\%; RCA:59.52\% i negativna predikativna vrednost LAD:91.19\%; RCA:90.48\%, dijagnostička pouzdanost LAD:66.67\%; RCA:75.00\% pri detekciji 
signifikatnih stenoza Kada su rezultati obe tehnike razmatrani zajedno dijagnostička pouzdanost je unapređena za LAD 97.33\%; RCA 90.00\%. Multivarijantna logistička analiza je ukazala na CFR za LAD i RCA kao neovisne prediktore kliničke prognoze

Zaključak: Zajednična, neinvazivna morfološka i funkcionalna procena je najpouzdaniji način dijagnostike signifikantnih koronarnih stenoza.

Ključne reči: neinvazivna dijagnostika, koronarna okluzivna bolest, koronarna rezerva protoka, Koronarna angiografija pomoću kompjuterizovane tomografije

Naučna oblast: Kardiologija

Uža naučna oblast: Neinvazivna kardiološka dijagnostika 


\title{
Diagnostic and Prognostic Value of Coronary Flow Reserve Determined by Transthoracic Doppler Echocardiography in Patients with Previously Performed Multi-Slice Computed Tomography
}

\begin{abstract}
:
Purpose: Multi-slice computed coronary angiography (MSCT) provides morphological information about coronary artery disease, but precise quantification of stenosis remains difficult. Transthoracic color Doppler Echocardiography (TDE) gives insight into the functional significance of coronary stenosis. We have tried to assess the additive diagnostic and prognostic value of coronary flow reserve (CFR) determined by TDE over MSCT in prediction of significant stenosis on the left anterior descending artery (LAD) and right coronary artery (RCA) using invasive coronary angiography (ICA) as reference method.
\end{abstract}

Methods: This prospective study included 84 patients, in stable cardiac status, with previously detected atherosclerotic lesions on LAD and/or RCA by MSCT. CFR assessment by TDE with adenosine was obtained in LAD $(n=75)$; RCA $(n=61)$, resulting in 136 vessels for analysis. ICA was preformed to all 24 to 48 hours after CFR.

Results: Cochrans $\mathrm{Q}$ test found a significant statistical difference between these techniques in detection of a significant stenosis on LAD and RCA ( $p<0.01$ ), further analyzes revealed a significant difference between MSCT and CFR ( $p<0.05$ ), MSCT and ICA ( $p<0.01)$, while between CFR and ICA we didn't find a significant difference ( $\mathrm{p}>0.05$ ). MSCT had sensitivity LAD:88.00\%; RCA:86.21, specificity LAD:57.63\%; RCA:69.10\%, positive LAD:46.81\%; RCA:59.52\% and negative predictive value LAD:91.19\%; RCA:90.48\%, diagnostic accuracy LAD:66.67\%; RCA:75.00\% in detection of significant stenosis. When the results of both methods were agreed diagnostic accuracy was 
improved LAD 97.33\%; RCA 90.00\%. Multivariate logistic analyses obtained that CFR for LAD and RCA were independent predictors in further clinical prognosis.

Conclusion: Comprehensive noninvasive anatomical and functional imaging would be the best way for detection of significant coronary artery lesions.

Key words: non invasive diagnostic, coronary artery disease, coronary flow reserve, multi-slice computed coronary angiography

Scientific field: Cardiology

Special topic: Noninvasive diagnostic of cardiology 


\section{Sadržaj:}

1. Uvod

1

1.1 Osnovne anatomske i fiziološke osobine koronarne cirkulacije 1

1.2 Ishemijska bolest srca 4

1.3 Neinvazivne dijagnostičke tehnike za detekciju koronarne okluzivne bolesti .7

1.3.1. Funkcionlani testovi za detekeciju koronarne bolesti 7

1.3.1.1. Transtorakalna Doppler ehokardiografska procena koronarne rezerve protoka (CFR) 8

1.3.2. Detekecija koronarne okluzivne bolest putem anatomskih testova 16

1.3.2.1. Koronarna angiografija pomoću kompjuterizovane tomografije (MSCT koronarografija) 17

1.4. Racionalna osnova ispitivanja i radna hipoteza 29

2. Ciljevi istraživanja 31

3. Materijal i metode .32

3.1. Koronarna angiografija pomoću kompjuterizovane "multislajsne" tomografije (MSCT koronarografija) 33

3.2. Transtorakalna Doppler ehokardiografska procena očuvanosti koronarne rezerve protoka po protokolu sa Adenozinom 34 
3.3. Invazivna koronarografija 36

3.4. Statistička analiza podataka 36

4. Rezultati 38

4.1. Opšte kliničke karakteristike pacijenata uključenih u studiju 38

4.2. Ehokardiografski i koronarografski parametri pacijenata 39

4.3. Procena dijagostičke vrednosti MSCT koronarografije $i$ TTDE-CFR pri proceni postojanja HD značajnih aterosklerotskih lezija na $\mathrm{LAD}$, uz invazivnu koronarografiju kao referentni metod 41

4.4. Procena dijagostičke vrednosti MSCT koronarografije i TTDE-CFR-a pri proceni postojanja HD značajnih aterosklerotskih lezija na RCA, uz invazivnu koronarografiju kao referentni metod. 49

4.5. Prognostička vrednost koronarne rezerve protoka određene putem TTDE kod bolesnika sa prethodno verfikovanim lezijama putem MSCT koronarografije u odnosu na pojavu neželjenih kardiovaskularnih događaja u periodu praćenja 56

5. Diskusija 58

5.1. Dijagnostička pouzdanost MSCT koronarografije pri detekciji koronarne okluzivne bolesti 60

5.2. Dijagnostička pouzdanost koronarne rezerve protoka (CFR-a) određene putem Transtorakalne Doppler ehokardiografije pri detekciji koronarne okluzivne bolesti 66 
5.3. Poređenje vrednosti koronarne rezerve protoka dobijene putem TTDE sa rezultatima MSCT koronarografije i rezultatima koronarne angiografije dobijene invazivnim putem kao referentom tehnikom 70

5.4. Prognostička vrednost koronarne rezerve protoka određene putem TTDE u odnosu na pojavu neželjenih kardiovaskularnih događaja i daljeg toka bolesti 75

5.5. Ograničenja sprovedene studije .78

6. Zaključak .79 


\section{UVOD}

\subsection{Osnovne anatomske i fiziološke osobine koronarne cirkulacije}

Koronarna cirkulacija je deo sistemske cirkulacije odgovoran za snadbevanje tkiva miokarda krvlju i razmenu materija. Ovu tkz. terminalnu arterijsku mrežu čine dve koronarne arterije prednja descedentna (LAD) i desna koronarna arterija (RCA), koje se odvajaju iza aortnih semilunarnih zalistaka, to jeste koronarnih sinusa i ispunjavaju krvlju za vreme povišenog pritiska u aorti tokom dijastole. Tokom svog epikardijlnog toka daju niz bočnih grana, koje se granaju na krvne sudove sve manjeg dijametra, koji potom poniru u sam miokard do subendokardijalnih slojeva. (Slika br.1)

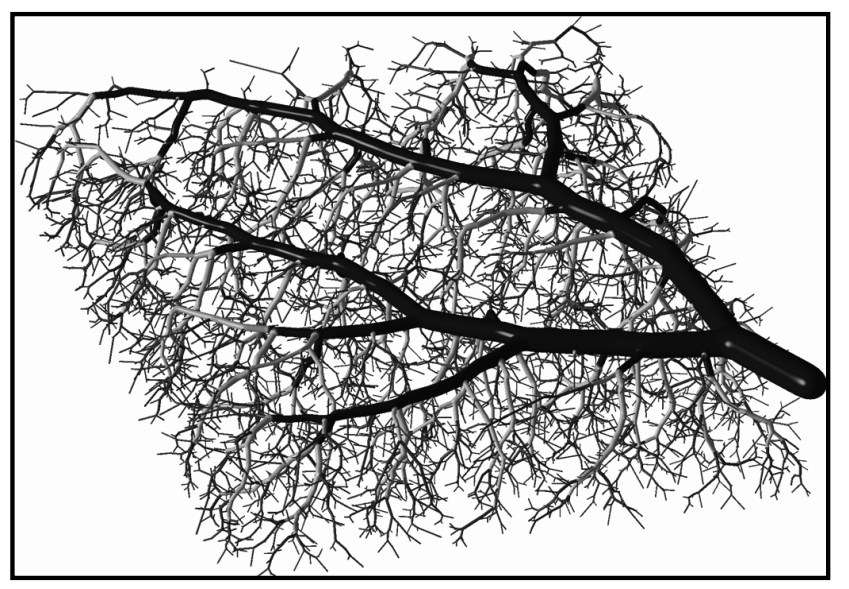

Slika br.1. Shematski prikaz koronarne cirkulacije 
Koronarna cirkulacija se može anatomski i funkcionalno podeliti u dva osnovna dela, veliki epikardijalni tkz. sprovodni koronarni krvni sudovi i rezistencijalni koronarni krvni sudovi dijametra manjeg od $300 \mu m$. Sprovodne koronarne arterije gotovo da ne pružaju otpor pri protoku krvi, dok ce značajno povećanje otpora nastupiti sa smanjenjem dijametra koronarnih krvnih sudova od malih arterija promera $300 \mu \mathrm{m}$ ka manjim arteriolama promera oko $100 \mu \mathrm{m}$. Razmena osnovih supstrata između tkiva i krvi se vrši isključivo na nivou kapilara (1). Protok krvi kroz sam miokard ce biti determinisan "koronarnim protočnim pritiskom” tj. gradijentom pritiska između aortnog korena i desne pretkomore. U fiziološkim uslovima gradijent pritiska se održava duž velikih epikardijlnih koronarnih arterija sa minimalnim gubitcima duž distalnih delova. Prolaskom krvi duž mikrovaskularne cirkulacije intrakoronarni pritisak se postepeno smanjuje najviše tokom prolaska krvi kroz arterije dijametra manjeg od $300 \mu \mathrm{m}$, dostižući pritisak od 20 - $30 \mathrm{mmHg}$, još uvek dovoljan za održavanje gradijenta kroz kapilarnu mrežu. Na celokupnu rezistenciju utiču i ekstravaskularni faktori: sistolni pritisak leve komore, kontraktilnost miokarda i srčana frekvenca. U cilju održanja adekvatnog protoka duž kapilarne mreže kao i razmene materija, neophodna je adekvatna i koordinisana interakcija između autoregulatornih mehanizama "koronarnog protočnog pritiska" i mikrovaskularne rezistencije. Ovi autoregulatorni mehanizmi kod smanjenja "koronarnog protočnog pritiska" dovode do pada i mikrovaskularne rezistencije i obrnuto, te koronarni protok ostaje na konstantnom nivou bez obzira na kardijalno opterećenje u fiziološkim uslovima (2). Porast protoka usled fizičkog opterećenja je najčešće prouzrokovan metabolički posredovanim smanjenjem mikrovaskularne rezistencije, najverovatnije usled razgradnje i oslabađanja adenozina iz adenozin monofosfata i relaksacije glatke muskulature koronarnih arterija. Rast protoka je potenciran i samim endotelin oslobađajućim faktorima. Odnosno, povećanje brzine protoka dovodi do porasta zidnog stresa i stimulacije endotelin NO sintetaze, te produkovani NO dovodi do relaksacije glatke muskulature u cilju prilgođavanja dijametra krvnih sudova, velikih epikardijalnih koronarnih arterija i mikovaskularne mreže povećanom protoku. Endotelijalne ćelije i glatko mišićne ćelije koronarnih krvnih sudova sadrže i 
adrenoreceptore, te su usled toga osetljive na lokalne i sistemske simpatičke stimuluse (3). (Slika br.2)

U fiziološkim okolnostima pri povećnim zahtevima miokarda za kiseonikom koronarni protok se povećava, zahvaljujući prethodno opisanim autoregularotnim mehanizmima .

Koronarni krvni sudovi su krvni sudovi relativno malog dijmetra i često bivaju zahvaćeni aterosklerozom tj procesom zadebljanja zida arterijskih krvnih sudova usled akumulacije lipidnog sadržaja i stvaranja plakova, dovodeći do redukcije već postojećeg malog lumena i smanjenja osetljivosti zida koronarnih krvnih sudova na postojeće autoregulatorne vazodilatatorne mahenizme.

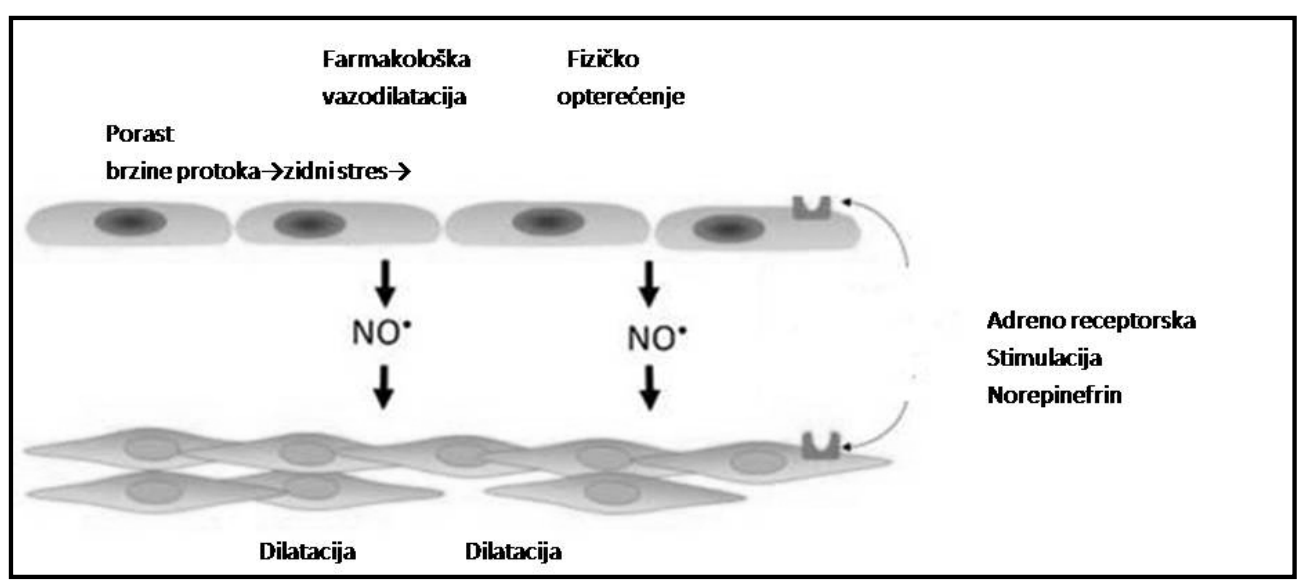

Slika br.2 Mehanizmi interakcije endotela i glatke muskulature krvnih sudova tokom vazodilatacije u fiziološkim uslovima, fizičkog opterećenja i tokom farmakološke dilatacije. 


\subsection{Ishemijska bolest srca}

Ishemija srčanog mišića kao patofiziološki supstrat ishemijske bolesti srca definiše se kao nedostatak kiseonika usled neadekvatne perfuzije srčanog mišića. Nastaje pri stanjima poremećene fiziološke ravnoteže između potreba i snadbevenosti miokarda krvlju. Kao najčešći etiološki faktor ovog disbalansa se smatra ateroskleroza epikardijalnih koronarnih krvnih sudova, koja sužavanjem njihovog dijametra smanjuje perfuziju srčanog mišića u bazalnim uslovima ili onemogućava adekvatan porast protoka u stanjima povećanih potreba miokarda za kiseonikom (4).

Usled smanjenjog priliva O2, kardimiociti prelaze sa aerobnog na anaeoroban matabolizam uz značajno smanjenje metaboličkih, električnih i mehaničkih funkcija. Srčana frekvenca, inotropni status i zidni stres miokarda su osnovne determinante metaboličke aktivnosti srčanog mišića i njegovih zahteva za kiseonikom. Porast srčane frekvence i kontraktilnosti će rezultovati i porastom zahteva miokarda za kiseonikom. Porast "'afterload"-a (npr. aortnog pritiska) i "preload"-a (npr.end dijastolni volumen) ce proporcionalno dovesti do rasta zidnog stresa miokarda i samim tim i do porasta zahteva miokarda za kiseonikom. Snadbevanje kiseonikom bilo kog organskog sistema je determinisano protokom krvi i estrakcijom O2. Saturacija O2 bazalnog venskog koronarnog protoka je oko 30\%, samim tim mogućnosti miokarda da potreban kiseonik obezbedi putem povećanja ekstrakcije su ograničene, te sve veći zahtevi za O2, bivaju obezbeđeni proporcionalnim rastom koronarnog protoka.

Koronarna okluzivna bolest je vodeći uzrok mortaliteta kod odraslih u većini zapadnih zemalja i $1 / 3$ svih uzrok smrtnosti (5). Uznapredovala forma koronarne bolesti često može perzistirati u gotovo asimptomatskom obliku, potom naglo progredirati ka iznenadnoj okluziji koronarne arterije sa često i fatalnim posledicama. Iznenadna srčana smrt je kod oko $18 \%$ bolesnika prva manifestacija koronarne bolesti (6). 
Poslednjih 20 - ak godina je zapažen značajan pad mortaliteta usled koronarne bolesti (7), što je posledica unapređenja kako dijagnostičkih procedura za ranu detekciju koronarne bolesti, tako i samih metoda lečenja koronarnih bolesnika. Poznavanje istorije bolesti, faktora rizika za kardiovaskularne bolesti, kao i dostupnost velikog broja neinvazivnih dijagnostičkih procedura omogućava ranu detekciju ateroskleroze, koronarne bolesti kao i procenu lokalizacije i proširenosti same ishemije miokarda. Postojeće dijagnostičke metode imaju svoje prednosti i nedostatke u odnosu na pojedine subpopulacije bolesnika, te se nijedna postojeća tehnika ne može smatrati idealnom za procenu svih bolesnika. Anatomski neinvazivni testovi zasnivaju se na proceni stepena stenoze tj. procenta redukcije lumena koronarne arterije. Nasuprot njima funkcionalni testovi koristeći se vazodilataronim ili inotropnim agensima vrše kvantitativnu procenu promene regionalnog koronarnog protoka i ishemije. Poređenjem njihovih nalaza uočen je veliki disparitet između strukturne i funkcionalne značajnosti uočenih aterosklerotskih lezija na koronarnim arterijama.

Rani eksperimentalni radovi Gould-a i saradnika su ukazali da bazalne vrednosti koronarnog protoka ostaju nepromenjene čak i u prisustvu stenoza dijametra do 90\% redukcije lumena koronarne arterije (Slika br. 3). Nasuprot bazalnim vrednostima koronarnog protoka, vrednosti koronarnog protoka pri maksimalnoj hiperemiji i vrednosti koronarne rezerve protoka bivaju značajno smanjene već u prisustvu stenoza dijametra većeg od 50\% (8). Koronarna rezerva protoka (CFR) se definiše kao odnos između koronarnog protoka u maksimalnoj hiperemiji i koronarnog protoka u bazalnim uslovima. U fiziološkim uslovima pri porastu opterećenja i zahteva miokarda za kiseonikom, porast bazalnih vrednosti koronarnog protoka u fazi maksimalne hiperemije je prosečno za 4 do 6 puta. Sa porastom stepena stenoze epikardijalne koronarne arterije, dolazi do postepenog pada perfuzionaog pritiska, te aktivacijom autoregulatornih mehanizama distalne arteriole se dilatiraju kako bi se održao bazalni protok. Tokom progresije aterosklerotskog plaka to stanje vazodilatiacije postaje hronično, smanjujući sposobnost povećanja protoka pri povećanim zahtevima miokarda, što posledično iscrpljuje koronarnu rezervu protoka. Kada CFR bude približno 1 , u svim situacijama porasta potrošnje $\mathrm{O} 2$ od strane miokarda dolazi do razvoja ishemije. 
Stvarna hemodinamska značajanost aterosklerotskih promena, samim tim i koronarna rezerva protoka najverovatnije nije uslovljena isključivo stepenom redukcije lumena koronarne arterije, nego i drugim parametrima lezije kao što su njena dužina, ekscentričnost, očuvanost endotelne funkcije i vazodilatatornih mehanizama, mada se ne može isključiti ni eventualna funkcionalna adaptacija krvnog suda na prethodne strukturne promene tokom izvesnog vremena tkz. "remodelling" koronarnih arterija.

Veliki broj aktuelnih, kao i sprovedenih komparativnih studija nastoji da precizira stvarni značaj morfoloških i funkcionalnih karakteristika aterosklerotskih lezija u prognozi i lečenju bolesnika sa koronarnom bolesti.

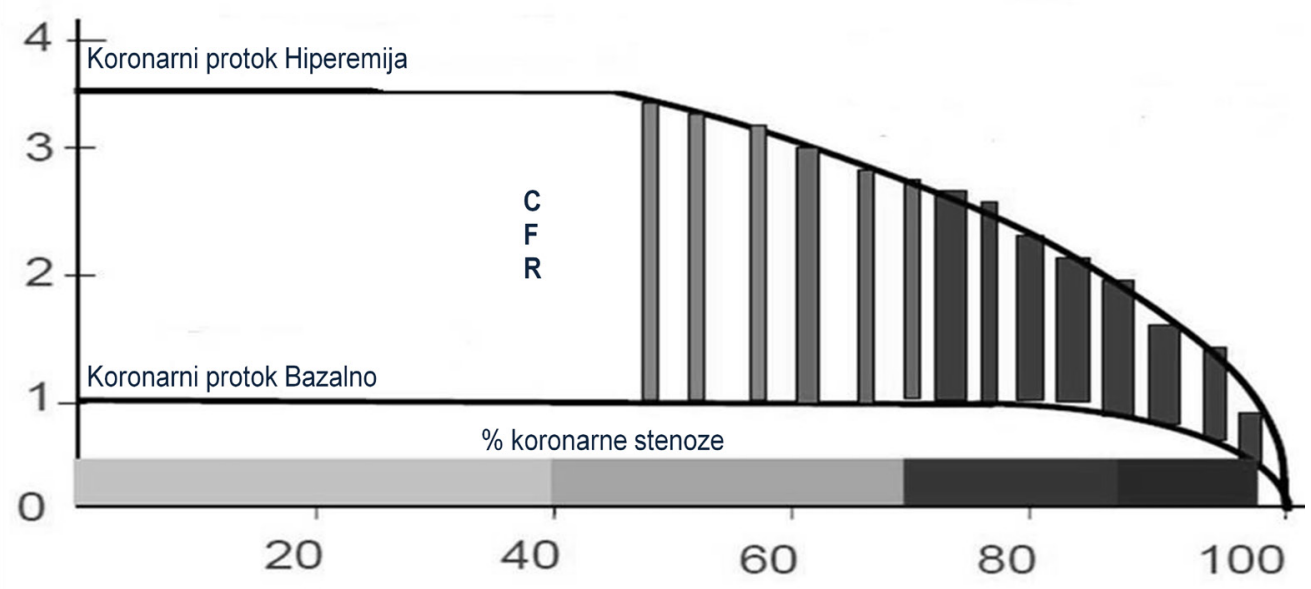

Slika br. 3 Shematski prikaz odnosa koronarnog protoka bazalno i pri maksimalnoj hiperemiji, sa porastom procenta redukcije lumena koronarne arterije

(Gould KL, Lipscomb K. Effects of coronary stenoses on coronary flow reserve and resistance. Am J Cardiol 1974; 34: 48-55) 


\subsection{Neinvazivne dijagnostičke tehnike za detekciju koronarne okluzivne bolesti}

\subsubsection{Funkcionlani testovi za detekeciju koronarne bolesti}

Osnova svih funkcionalnih testova za detekciju koronarne bolesti se zasniva na proceni stvarne hemodinamske značajnosti aterosklerotskih lezija epikardijalnih koronarnih arterija.

Ishemija je uvek posledica smanjenja očuvanosti koronarne rezerve protoka i disbalansa između zahteva i snadbevenosti miokarda kiseonikom.

Povećanje potrošnje miokarda se najčešće postiže putem fizičkog opterećenja /pokretna traka ili biciklom/ ili primenom beta agonista tj. dobutamina. Ukoliko pacijent ima fiksnu stenozu koronarne arterije, na kraju same provokacije dolazi do pojave indukovane ishemije usled disbalansa između zahteva miokarda za kiseonikom i snadbevanja.

Stres testovi sa primenom vazodilatatora kao što su adenozin, dipiridamol ili skorije upotrebljavani regadenosan se zasnivaju na osobinama vazodilatatornih agensa da indukuju heterogeni porast miokardnog protoka u prisustvu signifikantne koronarne stenoze. Porast perfuzije u regionu, koji irigira koronarna arterija sa opstruktivnom promenom je redukovan u odnosu na regione, koji se snadbevaju krvlju putem koronarnih arterija bez hemodinamski značajnih aterosklerotskih lezija. Heterogenost perfuzije tokom hiperemije se najbolje detektuje sa obeleživačima koronarnog protoka i manifestuje putem redukcije aktivnosti obeleživača.

Procena očuvanosti koronarne rezerve protoka zahteva primenu vazodilatatornih agensa, najčešće adenozina u cilju procene porasta koronarnog protoka u fazi maskimalne hiperemije. 
Najčešće korišćene tehnike za procenu funkcionalnog značaja su testovi sa fizičkim opterećenjem sa EKG monitoringom, stres ehokardiografija (SEHO), Emisiona kompjuterizovana tomografija pojedinačnim fotonima (SPECT), Pozitron Emisiona Tomografija (PET), Kardijalna Magnetna rezonanca (CMR) i poslednjih nekoliko godina Transtorakalna Doppler ehokardiografska procena očuvanosti koronarne rezerve protoka (CFR)

\subsubsection{Transtorakalna Doppler ehokardiografska procena koronarne rezerve protoka (CFR)}

Koronarna rezerva protoka predstavlja značajan funkcionalni parametar $\mathrm{u}$ razumevanju same patofiziologije koronarne cirkulacije. Njegova vrednost $\mathrm{u}$ kliničkoj praksi je često zanemarivana tokom prethodnih decenija zbog otežane i ograničene procene postojećim tehnikama. Evaluacija putem Intrakoronarnog Doppler katetera za procenu protoka (IDFW) je invazivna metodologija, dok je Pozitron emisiona tomografija tehnika retko dostupna i visoke cene koštanja. Procena CFR-a je moguća i putem transezofagealne ehokardiografije, koja je seminvazivna procedura, ali omogućava vizuelizaciju samo proksimalnih delova LAD.

Zahvaljujući razvoju tehnologije tokom poslednjih nekoliko godina sve veći broj studija ukazuje na značaj Transtorakalne Doppler ehokardiografske (TTDE) procene CFR-a. Metoda se odlikuje pouzdanošću, dostupnošću u svakodnevnoj kliničkoj praksi, reproducibilnošću, kao i niskom cenom. TTDE procena CFR-a se koristi za procenu koronarnih epikardijalnih stenoza, kao i mikrocirkulacije. 
Primena transtorakalne ehokardiografije u proceni koronarnog protoka zahteva adekvatan "setting" aparata i upotrebu sondi sa višim frekvencama transdjusera od 3,5 - $7 \mathrm{MHz}$. Dubinu pregleda je potrebno smanjiti tj. prilagoditi samoj anatomskoj lokalizaciji koronarnih arterija na površini srca, a brzinu signala Color Dopplera pri "mappingu" prilogoditi niskim brzinama koronarnog protoka od 12-16 cm/s, detekcija signala se vrši isključivo pulsnim Doppler-om.

Vizuelizacija što distalnijih segmenata posmatranih koronarnih arterija neophodna je iz tri osnovna razloga: 1. minimalizacija efekta ubrzanja protoka usled stenoza u medijalnim i proksimalnim delovima koronarnih arterija; 2. obezbedila bi se procena sekvencijalnih stenoza, koje ce svoj krajnji efekat na protok ispoljiti u distalnim delovima koronarne arterije; 3. poređenjem sa proksimalnim i srednjim segmentima koronarne arterije kapacitet distalnih delova je najmanji, te će i najadekvatnije reflektovati promene u intramuralnom protoku(9).

CFR dobijen proksimalno od stenoze je najčešce u zadovoljavajućim granicama, jer reflektuje protok u normalnim segmetnima. Na samom mestu stenoze dolazi do kompenzatornog ubrzanja protoka, kako bi se zadržao koronarni "output" i pored gubitka lumena, te usled toga nećemo dobiti realne i pouzdane vrednosti CFR-a (Slika br.4) 


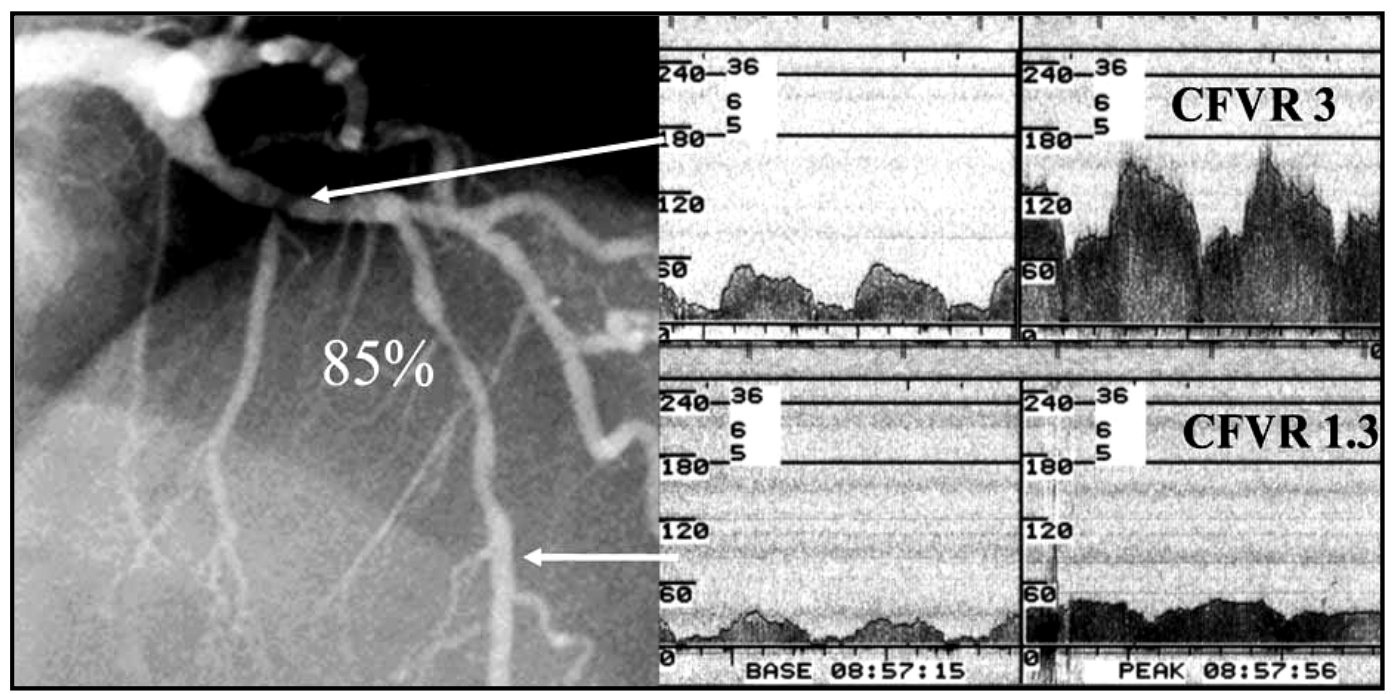

Slika br.4. Prikaz merenja CFR -a pre i posle stenoze koronarne arterije (Voci P, Pizzuto F, Romeo F. Coronary flow: a new asset for the echo lab? Eur Heart J 2004;25:1867-79

Distalni delovi LAD se najlaške vizuelizuju iz modifikovanog, apikalnog preseka 3 šupljine, u predelu sulcusa interventricularis anterior; distalni delovi ACX (ili njenih marginalnih arterija) se najlakše procenjuju u apikalnom preseku 4 šupljine u bazalnim ili medijalnim segmentima lateralnog zida; dok se distalni deo RCA tj. arterija posterior descedens interventricularis - PDA dobija u apikalnom preseku 2 šupljine u sulcusu interventricularis posterioris-u. (10, 11, 12, 13). (Slika br.5) 


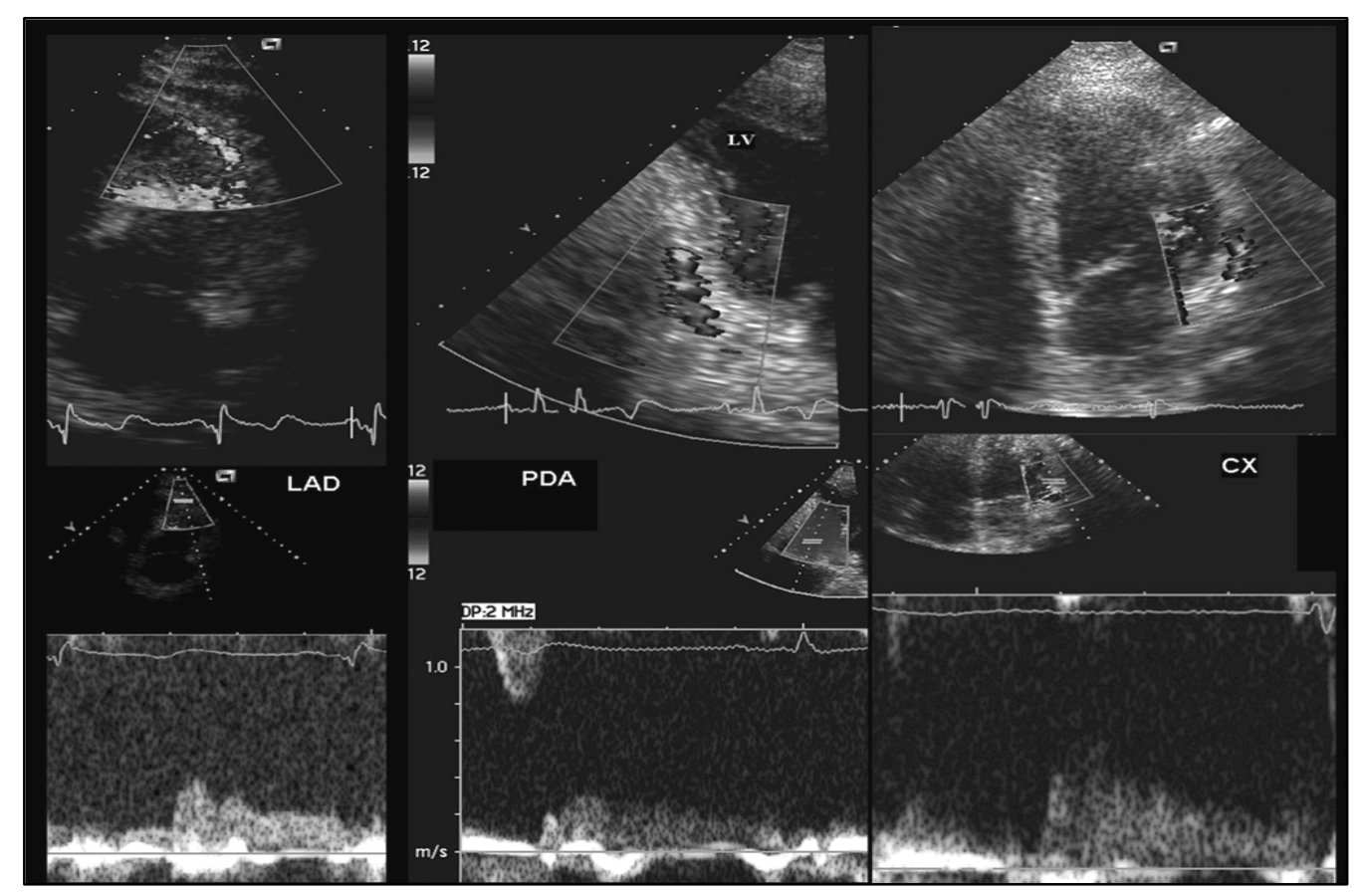

Slika br 5. Ilustrativni prikaz detekcije signala koronarnog protoka u LAD, ACX, RCA

Nakon "mapping-a“ signala putem Color Doppler-a, registrovanje signala se vrši pulsnim Doppler-om, uz prilagođavanje veličine ugla između signala koronarnog protoka i Doppler-a na vrednosti manje od $40^{\circ}$. Profil brzina koronarnog signala, registrovan pulsnim Doppler-om, je uvek bifazičan sa dominantnom dijastolnom komponentom. Nakon dobijanja bazalnih vrednosti koronarnog protoka i aplikacije vazodilatatora vrši se merenje brzina koronarnog protoka pri maksimalnoj hiperemiji, na istom mestu kao pri merenju bazalnih vrednosti.

TTDE-CFR se dobija kao količnik između prosečne vrednosti brzina koronarnog protoka pri maksimalnoj hiperemiji i prosečne vrednosti brzina koronarnog protoka u bazalnim uslovima. Koronarni protok u fazi hiperemije zavisi od ukupne koronarne rezistencije i u linearnoj je korelaciji sa koronarnim perfuzionim pritiskom (Slika br.6). 
Hiperemija se najčešće ostvaruje aplikacijom Adenozina $(0,14 \mu \mathrm{g} / \mathrm{kg} / \mathrm{min}) \mathrm{koji} \mathrm{je}$ snažan dilatator koronarne mirkocrikulacije, sa zanemarljivim efektima na same epikardijalne koronarne arterije. Koronarni protok predstavlja proizvod brzine protoka i poprečnog preseka koronarne arterije. Obzirom da je tokom primene Adenozina poprečni presek koronarne arterije konstantan, brzina se može smatrati ekvivalentom koronarnog protoka.(14) Procena CFR-a je moguća i primenom Dipridamola ali i nešto manje efikasna (15). Retko se primenjuje i Dobutamin koji porast koronarnog protoka ostvaruje drugim mehanizmima $(16,17)$

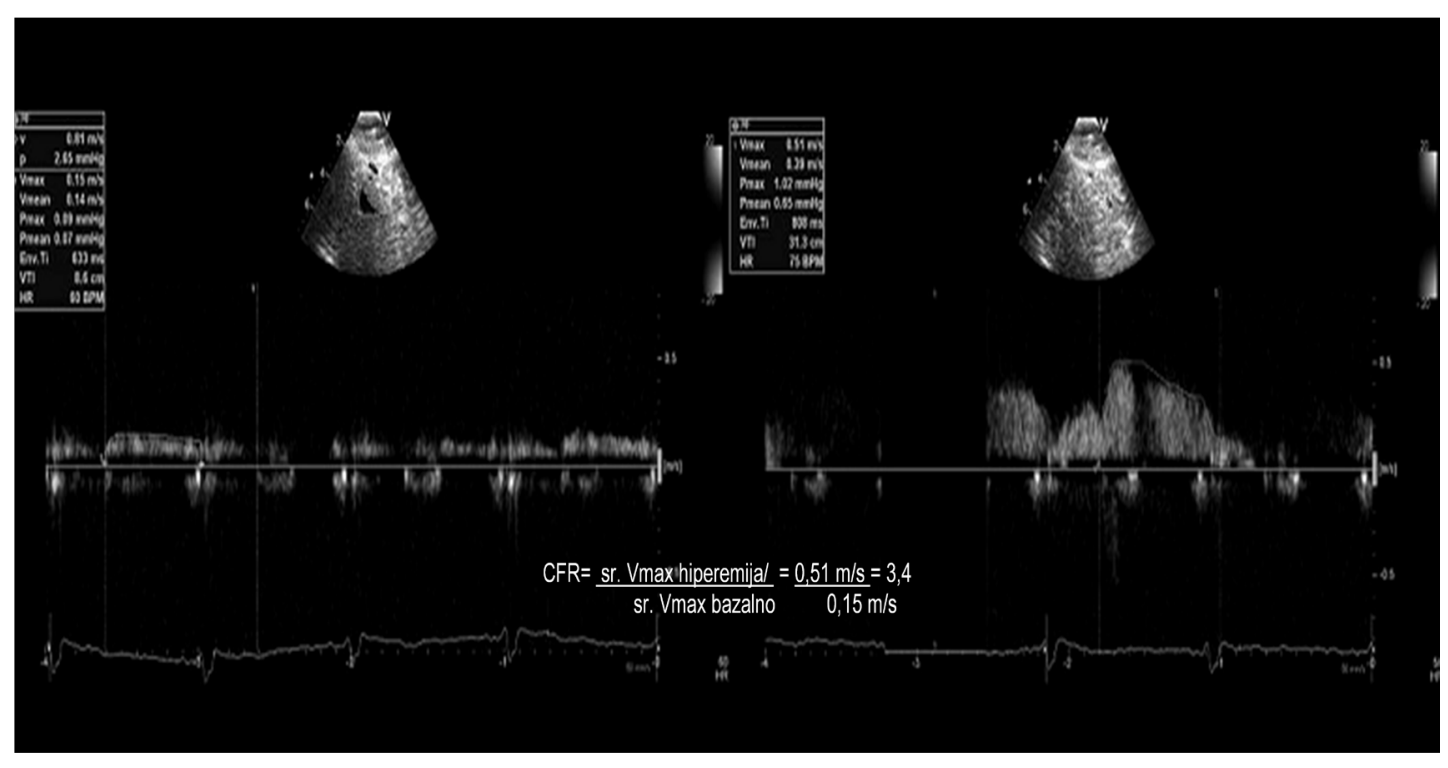

Slika br.6 TTDE - CFR distalnog segmenta LAD 
"Feasibility" tj. izvodljivost TTDE CFR-a za LAD je izrazito visoka i iznosi preko 90\% $(18,19,20)$, dok nakon aplikacije kontrasta može dosegnuti skoro i 100\% (21). "Feasibility" za RCA odnosno PDA je značajno niža usled tehničkih ograničenja, te u zavisnosti od studije iznosi od 54 do $86 \%$ (22-26). U poređenju sa LAD i PDA izvodljivost za ACX značajno varijabilnija i nepouzdanija, zbog često otežane vizuelizacije lateralnog zida. Najbolje rezultate su prezentovali Japanski autori i to poređenjem sa nuklearnim tehnikama 72\% i 73\%(27,28).

Komparativne studije su ukazale da su vrednosti CFR-a za LAD i PDA dobijene putem TTDE su u snažnoj korelaciji sa invazivnim merenjima FFR -a putem Intrakoronarnog Doppler katetera za procenu protoka (22,23,29-32).

TTDE procena CFR-a je pouzdana dijagnostička procedura za detekciju jednosudovne koronarne bolesti, ali kod višesudovne koronarne bolesti često nemamo mogućnost adekvatne vizuelizacije i izvodljivosti CFR-a u svim koronarnim arterijama.

Granična vrednost CFR-a od 2 se smatra pouzdanom za detekciju siginfikantne epikardijalne stenoze $\mathrm{i}$ ishemije u regionu, koji irigira posmatrana koronarna arterija $(13,18,21,33,34)$. Istraživanja su ukazala da i kod bolesnika sa brojnim činiocima, koji dovode do disfunkcije mikrocirkulacije kao što su pušenje, hiperlipidemija, diabetes mellitus, vrednost $\mathrm{CFR}<2$ je i dalje imala visoku senzitivnost 90\%, a specifičnost 93\%, pri detekciji signifikantne stenoze na LAD (33). Smatra se da hemodinamski signfikantne stenoze ipak dovode do mnogo značajnije proksimalne rezistencije u odnosu na obolenja mikrocirkulacije, što indirektno potvrđuje rana normalizacija CFR-a nakon sprovedne perkutane koronarne intervencije sa implantacijom stenta (PCI) (35).

Do sada sprovedene studije nisu ukazale na postojanje tačne granične vrednosti CFR-a za obolenja koronarne mikrocirkulacije, zbog njene podložnosti uticaju brojnih varijabilnog faktora, kao što su starosna dob, hipertenzija, Diabetes, hiperlipidemija, hipertrofija leve komore, menstrualni ciklusa kod žena (36-40) Transtorakalna Doppler ehokardiografska procena očuvanosti koronarne rezerve protoka, omogućava kvantitativnu procenu HD značajnosti aterosklerotskih lezija. Zahvaljujući svojoj neinvazivnosti, visokoj reproducibilnosti, neovisnosti rezultata od prethodne terapije i 
elektrokardiografskim promena, kratkom trajanju pregleda i praktično odsustvu neželjenih dejstava našla je značajnu primenu u kliničkoj praksi.

\section{Intermedijarne stenoze}

Shodno prethodnim istraživanjima nalazi TTDE CFR -a su u snažnoj korelaciji sa rezultatima invazivne koronarne angiografije, ukoliko posmatramo stenoze dijametra $<50 \%$, kao i hemodinamski značajne stenoze, dijametra >od $70 \%$ $(21,29,30,35)$. Precizna i pouzdana kvantifikacija intermedijarnih stenoza dijametra 50-69\% putem invazivne koronarne angiografije je praktično teško izvodljiva, te je stvarni hemodinamski efekat lezije odlučujući u proceni njihove stvarne značajnosti (41). Pri proceni stenoza intermedijarnog ranga, najčešće rezultati TTDE-CFR-a su značajno disperzniji u odnosu na rezultate invazivne koronarne angiografije (42). Nalazi TTDE-CFR-a mogu u značajnoj meri olakšati odluku o eventulanom sprovođenju revaskularizacije ili je bezbedno odložiti ukoliko je CFR očuvan (43).

Komparativne studije sa stres ehokardiografijom su ukazale da ce TTDE-CFR pouzdano detektovati lezije, koje tokom stres ehokardiografije neće dovesti do poremećaja u regionalnoj kontraktilnosti (20,44,45) Značaj evaluacije aterosklerotskih lezija putem TTDE-CFR-a je potvrđen i kod bolesnika sa više stenoza različitog promera, kroz studije koje su poredile rezultate TTDE-CFR-a sa nukelarnim tehikama $(18,51)$ i invazivnim merenjima FFR -a putem Intrakoronarnog Doppler katetera za procenu koronarnog protoka $(22,30,46)$.

\section{Restenoza nakon angioplastike (PCI)}

Ukoliko je u postproceduralnom praćenju CFR arterije na kojoj je sporovedena PCI sa implantacijom stenta snižen tj.<2, ukazivat će na restenozu sa senzitivnošću od 78 do $89 \%$ i specifičnošću od 90 do $93 \%(31,34,35)$ Snižena 
vrednost CFR-a je značajno senzitivniji djagnostički marker restenoze, ukoliko je detektovan tokom serijskog praćenja bolesnika u postprocedrualnom periodu.

\section{Akutni koronarni sindrom i akutni infarkt miokarda (AIM)}

U ovoj subpopulaciji bolesnika precizan značaj TTDE-CFR-a nije još determinisan, prevashodno zbog nedovoljno definisanog pravog vremena za njegovu primenu, usled dinamičnih i kompleksinih anatomskih i funkcionalnih promena na nivou koronarne mikrocirkulacije u postinfarktnom periodu. Najvećim delom zbog mikroembolizacije derbisom plaka, intersticijalnog edema i porasta vazomotornog tonusa. Izvesni autori su prezentovali podatke koji ukazuju da CFR <1,5 u infarktnoj arteriji nakon AIM lečenog reperfuzijom, ukazuje na značajno remodelovanje leve komore u postinfarktnom periodu. Između CFR-a i progresivne dilatacije leve komore bila je prisutna i značajna negativna korelacija u šestomesečnom periodu praćenja bolesnika nakon AIM (47). Collona i saradnici se u svom istraživanju uočili protektivni efekat preinfarktne anigne na očuvanost mikrocirkulacije i koronarne rezerve protoka u postinfarktnom toku bolesti(48).

\section{Procena prohodnosti koronarnih graftova nakon hiruške revaskularizacije miokarda}

je jedna od izrazito značajnijih kliničkih indikacija za primenu TTDE-CFR-a. U cilju postizanja najpouzdanije evaluacije prohodnosti grafta, signal je potrebno da bude detektovan distalno od anastomoze grafta, kako bi se dobio stvarni uvid $\mathrm{u}$ njegovo funkcionisanje. U suprotnom, procena protoka u samom graftu bi bila nepouzdana, jer je često pod uticajem signala protoka u samoj nativnoj koronarnoj arteriji, a sama predilekciona mesta za pojavu stenoze, kao mesto distalne insercije grafta ne bi bili obuhvaćeni pregledom. 
Rezultati do sada najveće sprovedene studije ukazuju da je "feasibility" tj. izvodljivost CFR-a za graft arterije mamarie interne za LAD bila skoro 100\%, za venski graft za LAD 91\%, za venski graft za RCA 96\% a za ACX 91\% (49). CFR $<1,9$ je imao senzitivnost $100 \%$, specifičnost $98 \%$ za procenu prohodnosti grafta arterije mamarie interne, dok CFR $<1,6$ je imao senzitivnost $91 \%$, specifičnost $87 \%$ za detekciju stenoze venskog grafta (49).

\section{Mikrovaskularna koronarna disfunkcija}

u prisustvu angiografski normalnih arterija se najčešće sreće kod bolesnika sa hipertrofijom miokarda, hipertenzijom, diabetes mellitus-om, pušenjem, menopauzom, aortnom stenozom (36-40). Oko 50\% bolesnika sa bolom u prekordijumu i normalnim koronarografskim nalazom je imao izvestan stepen mirkovaskularne disfunkcije, koji je i bio uzrok njihovih subjektivnih tegoba (50). Na osnovu nalaza TTDE-CFR a moguće je dobiti smernice za dalju primenu adekvatne farmakološke terapije i intezitetu monitoringa ovih bolesnika.

\subsubsection{Detekecija koronarne okluzivne bolest putem anatomskih testova}

Selektivna koronarografija prestavlja "zlatni" standard u proceni koronarne okluzivne bolesti, iako kod bolesnika sa difuznom koronarnom bolesti je moguće podceniti stvarnu težinu aterosklerotske lezije. $(52,53)$ 
Koronarografija je skupa dijagnostička tehnika, povezana sa izvesnim rizikom od potencijalno ozbiljnih komplikacija zbog same invazivnosti (54). U cilju unapređenja bezbednosti i smanjenja troškova lečenja sve su veće tendencije ka razvoju i primeni optimalne neinvazivne koronarne angiografije. Kod adekvatno selektovane subpopulacije bolesnika neinvazivna anatomska evaluacija koronarnih arterija bi mogla biti pouzdana "screening tehnika" u odnosu na postojeće funkcionalne testove. To bi značajno smanjilo broj invazivnih koronarografija kod bolesnika kod kojih imamo inkonkluzivne funkcionalne testove za procenu ishemijske bolesti srca (npr.LBBB). Značajno je istaći da bi se ovim metodama eventualno mogli dobiti i podaci o anomalnom ishodištu i toku koronarnih arterija, kao i o veličini aterosklerotskog plaka.

Koronarna angiografija pomoću tkz."multi slajsne" kompjuterizovane tomografije i koronarna angiografija putem magnetne rezonance su trenutno najčešce korišćene tehnike za neinvazvnu anatomsku evalauaciju koronarih arterija.

\subsubsection{Koronarna angiografija pomoću kompjuterizovane tomografije (MSCT koronarografija)}

\section{Tehnologija multi slajsnih skenera}

Kompjuterizovana tomografija je tokom poslednjih 25 godina postala značajna neinvazivna dijagnostička procedura. Njenu kliničku primenu inicijalno su ograničavale neadekvatna prostorna $\mathrm{i}$ vremenska rezolucija zbog čega je $\mathrm{u}$ početku najveći značaj imala u evaluaciji bolesti perikarda. Uvođenjem elektronske komjuterizovane tomografije pre $15^{-}$ak godina omugućena je 
kvanititativna procena prisustva kalcijuma kao osnovnog markera ateroskleroze. Osnove koronarne kompjuterizovane tomografije datiraju od 2000 te godine sa prvim "4 slice - nim" CT skenerom. Ovaj sistem je omogućio rotaciono vreme pokretnog postolja od oko o,5 sekundi sa detaljnim algoritmima za rekonstrukciju slika. Rekonstrukcija slike je vršena sa snimcima dobijenim tokom polovine samo jedne rotacije i sa temporalnom rezolucijom od oko $250 \mathrm{~ms}$. Istovremeno snimanje elektrokardiograma bolesnika je omogućilo sinhronizovanu rekonstrukciju slika sa pojednim fazama kardijalnog ciklusa. Prikazi dobijeni 4 slice-nim skenerom su ipak bili neadekvatnog kvaliteta zbog ograničene vremenske i prostorne rezolucije i tehnički često zahtevni zbog potrebe za zadržavanjem daha više of 40 sekundi. Dobijeni nalazi su često (više od 30\%) klasifikovani kao snimci neadekvatnog kvaliteta za interpretaciju (55,56). Daljim tehničkim usavršavanjem putem porasta brzine rotacije pokretnog postolja je omogućeno unapređenje vremenske rezolucije, dok je smanjenjem debljine preseka unapređena prostorna rezolucija. Porastom jačine zraka iz X cevi su smanjeni artefakti slika, te je skenerima omogućeno istovremeno skupljanje slika iz sve većeg broja simultanih preseka 4, 8, 16, 32, 40 i 64 tokom samo jedne rotacije (57- 65). Povećanjem broja preseka pokriven je veći volumen pregledanog materijala tokom jedne rotacije. Ovim putem je smanjena dužina snimanja, dužina zadržavanja udaha tokom prikupljanja podataka, posledično i količina potrebnog kontrastnog sredstva tokom izvođenja pregleda.

Postojeći i najčešće korišćeni skeneri sa 64 preseka i sa rotacionim vremenom pokretnog postolja od oko $420 \mathrm{msec}$, predstavljaju osnovu za vizuelizaciju lumena koronarnih arterija. Prosečna potreba za dužinom zadržavanja udaha sa „64 - slajsnim” skenerima je između 6 i 12 sekundi.

Svakako je potrebno istaći da sam broj preseka nije jedini parameter koji bi uticao na kvalitet prikaza koronarne cirkulacije. Dodatno povećanje broja preseka neznatno bi unapredilo tehničku izvodljivost samog pregleda. Interasantni su različiti stavovi o načinima unapređenja MSCT koronarografije. Jedno od stanovišta je da bi se porastom broja preseka povećao značajno volumen ispitanog materijala postignut tokom pregleda, te bi se tokom samo jednog ciklusa dobio adekvatan broj slika i infomacija, što bi ovu vrstu pregleda 
učinilo manje osetljivom na pojavu kardijalnih aritmija. Slični rezultati su dobijeni putem "256 slajasnog" skenera sa pribiližno 0,5 mlimetarskom kolimacijom, dok su vremenska i prostorna rezolucija ostale ne promenjene $(66,67)$.

Drugi pristup bi podrazumevao nepromenjen broj preseka 64, ali bi se koristili zraci iz $2 \mathrm{X}$ cevi i detektori smešteni u jednom pokretnom postolju, međusobno postavljeni pod uglom od $90^{\circ}$. Ovaj tkz. "dual source" CT bi omogućio prikupljanje podataka iz projekcija, koje su pod uglom od $180^{\circ}$ tokom samo $1 / 4$ rotacije pokretnog postolja, te vremenska rezolucija bila bi dvostruka veća $u$ odnosu na onu kod pokretnog postolja sa jednom X cevi i jednim detektorom, što bi najverovatnije značajno smanjilo broj artefakata usled pokreta $(68,69)$.

\section{Tehnika prikupljanja podataka za koronarnu angiografiju putem kompjuterizovane tomografije}

Najiskusniji centri vrše prethodnu pripremu pacijenata usporavanjem srčane frekvence ispod 65 ili $60 \mathrm{u}$ minutu, najčešce per oralnom ili intravenskom primenom beta blokatora. Također je poželjna i sublingvalna primena preparata nitrata u cilju maksimalne vazodilatacije koronarnih arterija, kako bi se unapredio kvalitet slike. Iako sam način snimanja zavisi i od tipa aparata prikupljanje visoko rezolutivnih "volumenskih baza podataka", koji obuhvataju samu untrašnjost srca predstavllja suštinu svih skenerskih protokola. Za snimanje je potrebno između 50 i $120 \mathrm{ml}$ kontrastnog sredstva i bolesnik je potrebno da zadrži dah između 6 i 20 sekundi (u zavisnosti od veličine srca i tipa skenera) Ekspozicija radijaciji tj. efektivna doza zračenja je između 3 i 15 $\mathrm{mSv}$ u zavisnosti od skenereskog protokola. Elektrokardiografski podešena modulacija rada cevi sa redukcijom zračenja tokom sistole omogućava smanjenje zračenja između 30 i 50\% (70). Projekcije pod uglom od oko $180^{\circ} \mathrm{su}$ neophodne za rekonstrukciju ukrštenih preseka. Ovi podaci se mogu dobiti sa jednom rotacijom pokretnog postolja za oko $180^{\circ}$ (vremenska rezolucija bi 
odgovarala $1 / 2$ rotacionog vremena). Na ovaj način bi svi podaci za rekonstrukciju jedne slike bili prikupljeni tokom samo jednog kardijalnog ciklusa.

Alternativni metod bi podrazumevao da se istovremeno prave snimci pod uglom od $180^{\circ}$ tokom nekoliko kardijalnih ciklusa. Vremenski period za dobijanje podataka tokom svakog kardijalnog ciklusa bi bio kraći od $1 / 2$ rotacionog vremena pokretnog postolja, a poželjno je da iznosi $1 / 8$ rotacije ukoliko su korišteni podaci iz 4 konsekutivna ciklusa. Svakako da bi efektivnost ovih tkz. multifaznih rekonstrukcionih algoritama zavisila od odnosa između srčane frekvence, rotacionog vremena, brzine kojom se postolje sa bolesnikom plasira u sami uređaj. Obzirom da ovaj odnos nije linearan, algoritmi su različito efikasni za različite srčane frekvence. Set podataka dobijen putem MSCT koronarografije će sadržati od 250 do 360 transaksijalnih preseka. Debljina preseka je obično između 0,5 i $1 \mathrm{~mm}$, dok ce preseci biti postavljeni na razdaljini manjoj od njihove debljine, te ce se konsekutivne slike delimično i preklapati. Snimci se najčešce premeštaju na isključenu radnu stanicu radi daljeg procesiranja $\mathrm{i}$ evaluacije. Dvodimenzionalne forme rekonstrukcije slika, kao što su multiplanarne rekonstrukcije ili projekcije maksimalnog inteziteta mogu značajno da olakšaju interpretaciju prikaza. Trodimenzionalna rekonstrukcija slika je vizuelno reprezentativnija, ali značajno manje korisna $\mathrm{u}$ evaluaciji podataka. Značajno je da slike mogu biti rekontruisane u bilo koje vreme i u bilo kom delu kardijalnog ciklusa. Rekonstrukcija nekoliko raspoloživih serija podataka omogućava dinamičku vizuelizaciju kardijalne funkcije. Analizom pokretljivosti leve komore se postiže bioprodukt koronarnog skener-a što omogućava pouzdanu procenu globalne i regionalne funkcije leve komore (71).

\section{Kvailitet slike i artefakti}

Regularna srčana frekvenca je preduslov za pouzdan prikaz koronarnih arterija putem kompjuterizovane tomografije. Smatra se da ograničena vremenska i 
prostorna rezolucija često dovode do artefakata, koji onemogućavaju adekvatanu evaluaciju koronarnih arterija. Pokreti ponekad dovode do razlivanja kontura koronarnih arterija. Desna koronarna arterija, koja često ima najbržu pokretljivost tokom kardijalnog ciklusa se najčešće prikazuje sa dosta artefakata. Teške kalcifikacije koronarnih arterija često mogu prekriti koronarni lumen zbog tkz. efekata parcijalnog volumena. Puno kontrasta rezultuje pojačavanjem efekta artefakta usled pokreta, te kalcifikacije mogu dovesti do lažno pozitivnih i lažno negativnih nalaza kod analize težine koronarnih stenoza. Rezultati nekoliko studija su ukazali da je pouzdanost procene težine koronarnih stenoza izrazito otežana u prisustvu kalcifikacija $(60,72,73)$. Srčana frekvenca je predikativna u odnosu na kvalitet slike, niže vrednosti frekvence značajno unapređuju kvalitet, vidljivost arterija i preciznost pri proceni težine stenoza koronarnih arterija (73-76).

\section{Detekcija stenoza koronarnih arterija}

Postojeći izveštaji ukazuju na visoku senzitivnost i specifičnost pri detekciji stenoza koronarnih arterija putem 16 - "slajsne" i 64 - "slajsne" MSCT koronarografije. (Tabela br.1)

Većina studija je obuhvatala između 50 i 100 pacijentata koji su bili izrazito selektovana populacija (npr. isključeni su svi pacijenti sa aritmijama, hroničnom renalnom insuficijencijom, mnoge su isključile i bolesnike u nestabilnom statusu ili sa prethodno dokazanom koronarnom bolesti i često su uključivale one kod kojih već indikovana invazivna koronarografija). Analiza je najčešce bila ograničena na segmente veće od 1,5 do $2 \mathrm{~mm}$. Sve studije iskusnih centara prezentuju senzitivnost između 83 - 99\%, specifičnost $93-98 \%$ pri detekciji okluzivnih lezija, dok je procenat neinterpretabilnih koronarnih segmenata bio između o i 12\%. Značajno je istaći visoku negativnu predikativnu vrednost između $95-100 \%$. 
Iako su ovakvi rezultati delom posledica niske prevalence koronarnih stenoza u većini studija, svakako ukazuju na pouzdanost MSCT koronarografije pri isključenju postojanja signifikantne koronarne bolesti. (Tabela br.1)

Tabela. 1. Pouzdanost MSCT koronarografije (16 i 64 preseka) u nekoliko studija pri detekciji koronarne stenoze (poređenje sa invazivnom koronarografijom)

\begin{tabular}{|c|c|c|c|c|c|}
\hline Autor & $\mathbf{N}$ & Kolimacija & Sens. & Spec. & $\begin{array}{l}\text { NPV } \\
(\%)\end{array}$ \\
\hline Kuettner et al. (77) & 124 & $16 \times 0.75$ & 85 & 98 & 96 \\
\hline Mollet et al. (78) & 51 & $16 \times 0.75$ & 95 & 98 & 99 \\
\hline Martuscelli et al. (58) & 64 & $16 \times 0.625$ & 89 & 98 & 98 \\
\hline MorganHughes et al. (61) & 58 & $16 \times 0.625$ & 83 & 97 & 97 \\
\hline Schujif et al. (79) & 45 & $16 \times 0.75$ & 98 & 97 & 100 \\
\hline Hoffmann et al. (80) & 103 & $16 \times 0.75$ & 95 & 98 & 99 \\
\hline Achenbach et al. (81) & 50 & $16 \times 0.75$ & 94 & 96 & 99 \\
\hline Leschka et al. (82) & 53 & $64 \times 0.6$ & 94 & 97 & 99 \\
\hline Raff et al. (83) & 70 & $64 \times 0.6$ & 86 & 95 & 98 \\
\hline \multirow[t]{2}{*}{ Leber et al. (62) } & 59 & $64 \times 0.6$ & 73 & 97 & 99 \\
\hline & & & $88^{*}$ & $97^{*}$ & $99^{*}$ \\
\hline Mollet et al. (84) & 52 & $64 \times 0.6$ & 99 & 95 & 99 \\
\hline Ropers et al. (63) & 82 & $64 \times 0.6$ & 95 & 93 & 99 \\
\hline Fine et al. (64) & 66 & $64 \times 0.6$ & 95 & 96 & 95 \\
\hline
\end{tabular}

N-broj pacijenata, Senz.-senzitivnost, Spec.-specifičnost, NPV-negativna predikativna vrednost

(Achenbach S. Computed Tomography Coronary Angiography. J Am Coll Cardiol 2006;48:1919) 
Koronarna angiografija putem "multislajsne" kompjuterizovane tomografije ima svoja značajna ograničenja, te se ne može očekivati da ce u potpunosti zameniti invazivnu selektivnu koronarografiju u skorijoj budućnosti. Prostorna rezolucija onemogućava precizno kvantifikovanje težine stenoze koronarne arterije. Dodatna ograničenja u njenoj primeni su aritmije, blješteći efekti kalcifikacija, brzi pokreti koronarnih arterija, kao i alergija na jodna kontrastna sredstva.

Ovo je isključivo anatomski prikaz koronarne cirkulacije, bez mogućnosti procene hemodinamskog značaja koronarnih stenoza.

Suštinska razlika u odnosu na invazivnu koronarografiju je i nemogućnost sprovođenja neposrednih intervencija. Bolesnici sa tipičnom kliničkom slikom ishemijske bolesti srca i jasno pozitivnim testovima opterećenja, neće imati značajnu korist od bilo kojeg tipa neinvazivne "multislajsne" koronarografije. Nasuprot ovoj populaciji simptomatični bolesnici, koji imaju malu verovatnoću da se radi koronarnoj bolesti, će usled visoke negativne predikativne vrednosti ove metode moći izbeći dalju invazivnu kardiološku dijagnostiku. Dosadašnji rezultati ukazuju na gotovo identičnu pouzdanost ove metode i u ženskoj populaciji(85), kao i kod bolesnika sa LBBB (86) što je njena značajna prednost u odnosu na druge neinvazivne dijagnostičke tehnike.

MSCT koronarografija je često upotrebljavana za detekciju kalcifikacija koronarnih arterija. Istraživanja su ukazala na postojanje jasne korelacije u proceni aterosklerostkih lezija, između Ca skora i histoloških analiza, nalaza intravaskularnog ultrazvuka i angiografije (87-90). MSCT koronarografija bez primene kontrasta je imala izrazito nisku senzitivnost za detekciju nekalcifikovanih plakova (88), a u jednoj od studija je uočeno da je veličina poprečnog preseka aree plaka tokom histopatološkog pregleda bila oko 5 puta veća od kalcifikacione aree izmerene putem MSCT koronarografije (87). U ranim fazama ateroskleroze primećeno je kompenzatorno uvećanje arterija, kako bi se prilagodile rastu samog plaka. Ovaj fenomen je opisan kao vaskularno remodelovanje (91). Agaston skor je zbog značajne dijagnostičke i prognostičke vrednosti proveren i najčešće korišen način merenja prisustva kalcijuma. (92), dok procene preko volumenskog skora $\mathrm{Ca}$ i Ca mase zahtevaju sprovođenje 
većih studija. Zaključeno je da Ca skor i kod muškaraca i žena ima visoku senzitivnost pri detekciji stenoza dijametra preko 50\%, dok je specifičnost umerena i značajno manja kod pojedinaca starijih od 60 godina. Analizom 16 studija Ca skor izmeren putem MSCT koronarografije je imao senzitivnost 91\% i specifičnost 49\% (93). Samo odsustvo Ca je visoko predikativno za nepostojanje koronarne ateroskleroze (94). U brojnim do sada sprovedenim studijama najčešće se koristi sledeći odnos gradacije između Ca skora i veličine aterosklerotskog plaka (95-98):

- $\mathrm{o}$ - nedetektabilna ateroskleroza

- 1 to 99 - lako izražena ateroskleroza

- 100 to 399 - umerena ateroskleroza

- $\geq 400$ - okluzivne aterosklerotske promene

Rezultati skorašnje ACCURACY studije ukazuju da je specifičnost MSCT koronarografije za detekciju signifikatnih aterosklerotskih promena značajno umanjena (od 86\% do 53\%) kod bolesnika sa visokim Agaston skorom preko 400 (99). (Slika br.7) Masivne kalcifikacije često dovode do precenjenosti posmatranih lezija, te bi MSCT koronarografija imala značajno manju vrednost u kliničkoj praksi kod bolesnika sa hroničnom bubrežnom insuficijencijom i u starijoj populaciji. Bolesnici sa hroničnom anginom pektoris ili akutnim koronarnim sindrom najčešće imaju parcijalno kalcifikovanu kritičnu leziju (105), mada i poptuno odsustvo kalcijuma ne isključuje postojanje neopstruktivnih i opstruktivnih aterosklerotskih promena (106).

Sadašnji rezultati kliničkih ispitivanja ne podržavaju rutinsku primenu MSCT koronarografije kao "screening" metode u asimptomatskoj populaciji. Iako primena MSCT koronarografije u detekciji prognostički značajnih signifikantih stenoza (npr. left main stenosis) kod visoko rizične populacije bolesnika (npr. dijabetičari) bi imala svoju primenu ali je nepohodna potvrda stvarne vrednosti kroz prospektivne kliničke studije. 


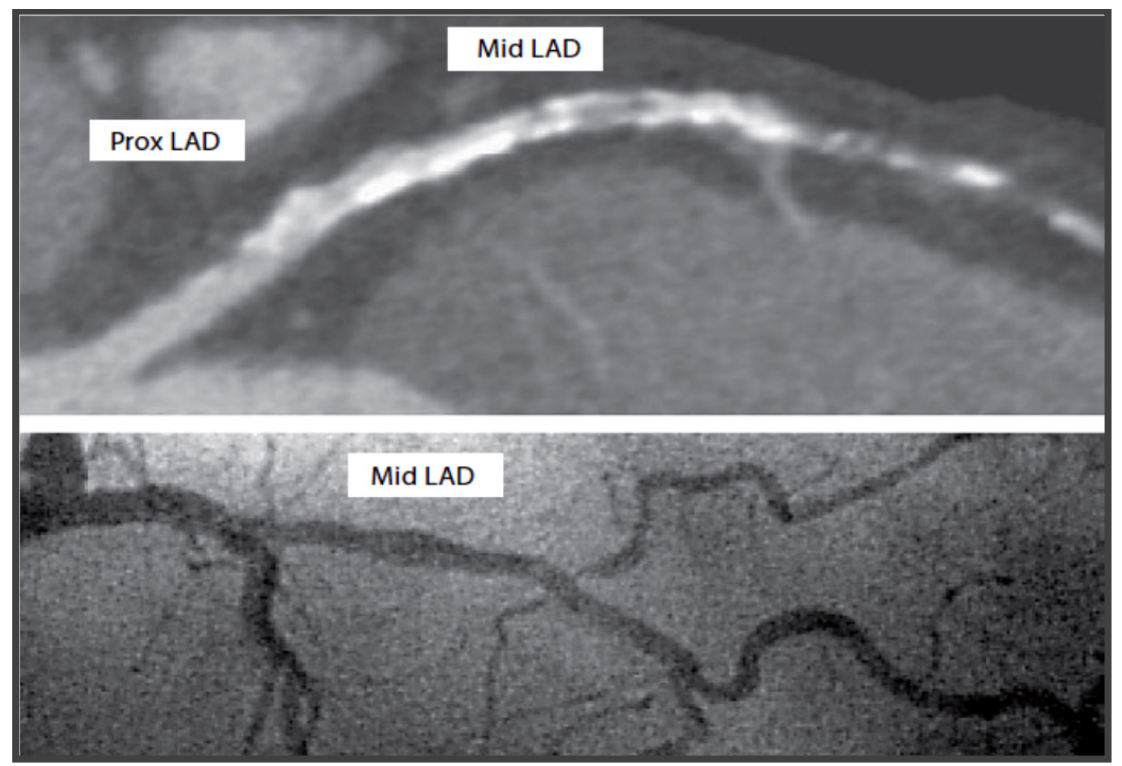

Slika br. 7 Prednja descedentna arterija LAD: intermedijarna stenoza

(gornji deo slike prikaz putem MSCT kontrastne koronarografije, gde prisustvo difuznih i teških kalcifikacija onemogućava realnu procenu stepena stenoze; donji deo slike invazivna koronarografija stenoza intermedijarnog stepena $u$ medijalnom segementu LAD) (Halon D, Rubinshtein R, Gaspar T. Current Status and Clinical Applications of Cardiac Multidetector Computed Tomography. Cardiology 2008;109:73-84)

\section{By pass graftovi}

Prikaz by pass graftova je značajno lakši u odnosu na nativne koronarne krvne sudove, jer su značajno većeg dijametra i manje brzine pokretljivosti. Snimanje graftova arterije mamarie interne je najčešće otežano usled artefakata nastalih zbog metalnih klipsi duž samog grafta. Nekoliko studija sprovedenih sa 16 slajnim skenerom je ukazalo na visoku pouzdanost pri njihovom snimanju. 
Mayer i saradnici su referisali da je "64 slajsna" MSCT koronarografija u proceni prohodnosti by pass graftova imala senzitivnost $97 \%$ i specifičnost $97 \%$, pozitivnu predikativnu vrednost (PPV) 93\% i negativnu predikativnu vrednost (NPV) 99\%. Arterijski graftovi zbog svojih nešto manjih promera su imali nešto manju senzitivnost $93 \%$ i specifičnost 86\% (100). Rezultati su ukazali na otežanu i nepouzdanu procenu nativnih koronarnih arterija, posebno delova distalno od mesta insrecije grafta. Procena nativnih koronarnih arterija može biti izrazito otežana zbog njihove ubrzane kalcifikacije nakon plasiranja graftova, kao i njihove izrazito male veličine.

Ova ograničenja onemogućavaju pouzdanu primenu MSCT koronarografije kod bolesnika sa anginoznim tegobama nakon by pass hirurgije kod kojih je potrebna procena kako graftova, tako i samih nativnih koronarnih arterija.

\section{Stentovi koronarnih arterija}

Prikazivanje lumena koronarnih arterija sa prethodno implantiranim stentovima je značajno otežano artefaktima, tj. bještećim senkama samog metala te su ovi segmenti najčešce neinterpretabilni. Skeneri slabije rezolucije praktično su bili neupotrebljivi za procenu većine stentova posebno onih dijametra manjeg od $3 \mathrm{~mm}$. Gaspar i sardnici su prezentovali rezultate sa 40 "slajnim" skenerom koji ukazuju da je svih 111 stentova bilo dostupno proceni, ali je samo $72 \%$ in stent restenoza detektovano (101). Uprokos poteškoćama kod većine bolesnika sama vidljivost lumena stenta je dovoljna da isključi pojavu restenoze (102). (Slika br.11) Studija urađena na 68 bolesnika i 112 stentova postavljenih neposredno pre invazivne koronarografije idikovane zbog rekurentih anginoznih tegoba, ukazala je da je MSCT koronarografija imala senzitivnost $89 \%$, specifičnost $97 \%$ i negativnu predikativnu vrednost od $97 \%$ pri detekciji in stent restenoze (suženje dijametra preko 60\%) (103). Ehara i saradnici su prezentovali da je sa MSCT 64 "slajsnim" skenerom 88\% stentova bilo dostupno pregledu, sa senzitivnošću 91\%, specifičnošću 93\%, pozitivnom 77\% i negativnom predikativnom vrednošću 98\%, 2 lezije nisu uočene putem 
MSCT koronarografije, dok je 6 lezija bilo precenjeno (104). Iz navedenog se može zaključiti da će procena intermedijarnih stenoza, posebno kod manjih stentova i prisustva teških segmentnih kalcifikacija imati značajno ograničenu pouzdanost Skeneri budućih generacija ce svakako poboljšati procenu prohodnosti stentova, ali i dalje invazivna koronarografija je ostaje suveren metod za njihovu evaluaciju.

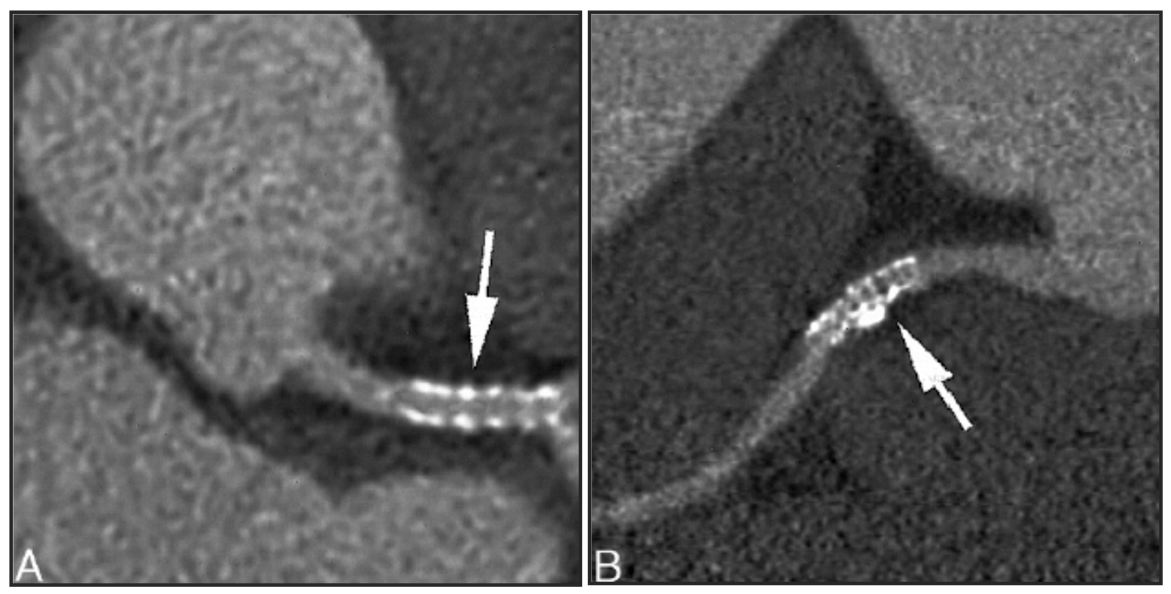

Slika br.8 A: Prikaz stenta dijametra $3,5 \mathrm{~mm}$ u distalnom segmentu LAD neposredno pre bifurkacije, koji jes prohodan,B: stent plasiran u RCA djametra 3,5mm usled artefakta pouzdna procena prohodnosti nije moguća (Achenbach S. Computed Tomography Coronary Angiography. J Am Coll Cardiol 2006;48:1919 -28) 


\section{Procena koronarnih aterosklerotskih plakova}

MSCT koronarografija omogućava vizuelizaciju i koronarnog lumena i samog aterosklerotskog plaka u zidu koronarne arterije, koji se po primeni kontrastnog sredstva prikazuju kao odvojena struktura od samog lumena. Aterom se vizuelizuje kao zadebljanje u zida krvnog suda, koje može biti difuzno ili lokalizovano. Aterom može imati manju gustinu od kontrastom obojenog lumena koronarne arterije, ali ipak nešto većeg inteziteta u odnosu na okolno periarterijsko masno tkivo to su tkz. "mekani plakovi". Kalcifikovani plakovi su oni sa snažnom atenuacijom X zraka, koji su odvojeni i gušći od lumena arterije. Često u sastavu jednog plaka možemo imati i tkz. mekane i kalcifikovane delove. Nekoliko komparativnih studija sa intravaskularnim ultrazvukom su potvrdile jasnu korelaciju između ove 2 tehnike, stim što su rezultati putem MSCT koronarografije često podcenjivali stvarnu veličinu plaka $(87,62,107)$. MSCT koronarografija nam omogućava i vizuelizaciju malih, multiplih kalcifikacija, koje su čest nalaz kod bolesnika sa akutnim koronarnim sindromom $(105,107,108)$. Prisustvo mekih plakova može da koreliše sa veličnom lipidnog bazena i nekrotičnog jezgra u samom plaku, što je jedna od predispozicija za nastanak akutnog koronarnog sindorma (107) Prethodna istraživanja su uočila jasnu korelaciju između multiplih faktora rizika za koronarnu bolest i opsega aterosklerotskih lezija (109), ali predikativna vrednost plakova i njihovih karakteristika u odnosu na buduće koronarne događaje tek treba da se ustanovi na osnovu većih prospektivnih studija. 


\subsection{Racionalna osnova ispitivanja i radna hipoteza}

Tokom poslednje decenije brojna savremena kardiološka ispitivanja su usmerena ka intezivnom radu na unapređenju dijagnostike koronarne bolesti. Transtorakalna Doppler ehokardiografska procena očuvanosti koronarne rezerve protoka je omogućila neinvazivnu procenu funkcionalne značajnosti aterosklerotskih lezija koronarnih arterija. Dijagnostički i prognostički značaj CFR-a određenog putem TTDE je do sada dokazan kroz brojne prethodno sprovedene studije.

Koronarna angiografija "64-slajsnom" kompjuterizovanom tomografijom je široko rasprostranjena neinvazivna dijagnostička procedura koja omogućava vizuelizaciju morfoloških karakteristika aterosklerotskih lezija gotovo celog koronarnog vaskularnog korita. Osnovno ograničenje pri njenoj primeni je precenjenost težine detektovanih lezija.

Tokom našeg istraživanja pokušali bi smo da determinišemo značaj procene CFR-a kod bolesnika sa prethodno verifikovanim promenama putem MSCT koronarne angiografije, kao jedne od novijih i značajnih neinvazivnih procedura za detekciju koronarne bolesti. U savremenoj literaturi do sada su objavljeni rezultati samo jedne studije Pizzuta i saradnika (131), koja se bavila promenama detektovanim "40 slajsnom" MSCT koronarografijom samo na LAD. Naše istraživanje bi za razliku od većine drugih studija bilo sprovedeno na LAD i RCA, u heterogenoj kardiološkoj populaciji uključujući i bolesnike sa izraženom ateromatozom i često prisutnim kalcifikacijama, kao što su bolesnici starije životne dobi, dijabetičari, kao i oni sa prethodno sprovedenom revaskularizacijom miokarda bilo putem PCI ili koronarne hirurgije.

Obzirom, na značajno umanjenu pozitivnu predikativnu vrednost MSCT koronarografije, dodatno procenjivanje očuvanosti koronarne rezerve 
protoka bi omogućilo procenu stvarne fiziološke značajnosti prethodno detektovanih promena a samim tim i donošenje adekvatnih odluka pri izboru daljih dijagnostičkih i terapijskih procedura.

Shodno prethodno izloženom naša radna hipoteza bi bila da ćemo na osnovu merenja CFR-a putem transtorakalne Doppler ehokardiografije odrediti stvarni hemodinamski značaj aterosklerotskih promena detektovanih pomoću MSCT koronarografije, što će doprineti povećanju senzitivnosti, specifičnosti i dijagnostičke pouzanosti pri dijagnostici koronarne bolesti, kao i da će rezultati TTDE CFR-a predstavljati značajan prognostički faktor daljeg kliničkog toka bolesti. 


\section{CILJEVI ISTRAŽIVANJA}

Ciljevi ovog istraživanja, koje je prospektivno i eksperimentalnog tipa, gde su pacijenti sami sebi kontrolna grupa, su bili da se određivanjem koronarne rezerve protoka transtorakalnom Doppler ehokardiografijom ispita stvarni hemodinamski značaj aterosklerotskih promena prethodno detektovanih pomoću visokorezolutivne kompjuterizovane tomografije koronarnih arterija putem određivanja:

1. Senzitivnosti, specifičnosti i dijagnostičke tačnosti MSCT koronarografije u detekciji koronarne okluzivne bolesti

2. Senzitivnosti, specifičnosti i dijagnostičke tačnosti određivanja CFR putem TTDE u proceni stvarne hemodinamske značajnosti aterosklerotskih lezija na koronarnim arterijama prethodno verifikovanim putem MSCT koronarografije

3. Poređenja vrednosti koronarne rezerve protoka dobijene putem TTDE sa rezultatima MSCT koronarografije i rezultatima koronarne angiografije dobijene invazivnim putem

4. Prognostičke vrednosti koronarne rezerve protoka određene putem TTDE kod bolesnika sa prethodno verfikovanim lezijama putem MSCT koronarografije $\mathrm{u}$ odnosu na pojavu neželjenih kardiovaskularnih događaja u periodu praćenja 


\section{MATERIJAL I METODE}

Studija je bila prospektivnog karaktera, uključeno je 84 bolesnika, koji su hospitalizovani u Klinici za Kardiologiju, Vojno Medicinske Akademije u Beogradu zbog sprovođenja invazivne kardiološke dijagnostike, selektivne koronarografije u periodu od januara 2010 do marta 2011 godine.

$\mathrm{U}$ istraživanje su uključeni bolesnici sa suspektnom ili već prethodno dijagnostikovanom koronarnom bolešću, kod kojih je zbog anginoznih tegoba i prethodno inkonkluzivnih testova sa fizičkim opterećenjem po Bruceovom protokolu ili stres testova, indikovana i sprovedena koronarna angiografija pomoću kompjuterizovane "multislajsne" tomografije ambulantno.

Uključeni su isključivo bolesnici, kojima je prethodno ambulantno putem MSCT koronarografije detektovano postojanje suspektnih aterosklerotskih lezija na koronarnim arterijama LADili/i RCA nalazi interpretirani shodno važećim preporukama (110), te je indikovano sprovođenje invazivne koronarografije, što je bio i razlog njihove hospitalizacije u našoj ustanovi.

Bolesnici sa dokazanim teškim valvularnim manama, bolestima perikarda, idopatskom dilatativnom i hipertrofičnom kardiomiopatijom, kongenitalnim srčanim manama, hroničnom opstruktivnom bolešću pluća, promećajima ritma tipa bradikardija, ekstrasistolne aritmije nisu razmatrani kao kandidati za uključivanje u istraživanje.

Pre ulaska u studijsku grupu bolesnika shodno važećim propozicijama etičkog komiteta od svakog pacijenta je dobijen pismeni pristanak nakon prethodnog detaljnog objašenjenja.

Neposredno po hospitalizaciji kod svih bolesnika su urađene osnovne laboratorijske analize, radiografija srca i pluća, transtorakalna ehokardiografija.

Potom je izvršena i procena funkcionalne značajnosti, stenoza prethodno detektovanih MSCT koronarografijom, putem transtorakalne Doppler 
ehokardiografske procene očuvanosti koronarne rezerve protoka (CFR a) na izmenjenim koronarnim arterijama.

Svim bolesnicima je posle 24 do $48 \mathrm{~h}$ urađena i invazivna selektivna koronarografija.

Nakon sprovedene dijagnostike, dalje lečenje i pojava neželjenih kardijalnih dešavanja opservirani su u periodu oko 6 meseci.

\subsection{Koronarna angiografija pomoću kompjuterizovane "multislajsne" tomografije (MSCT koronarografija)}

Sva snimanja skenerom sprovedena su na 64- "slajsnom" skeneru sa rotacionim vremenom od o,33 sekunde (Toshiba, Aquilion, 64). Bolus od $80 \mathrm{ml} \mathrm{mL}$ Iodixanol (Visipaque $320 \mathrm{mg} / \mathrm{mL}$, Amersham Health, Buckinghamshire, UK) je intravenski davan u antekubitalnu venu brzinom od $5 \mathrm{ml} / \mathrm{s}$, potom bolus od $50 \mathrm{ml}$ slanog rastvora. Incijalno kašnjenje je definisano praćenjem pojave bolusa u descedentnoj aorti, a sa skeniranjem se započinjalo automatski 5 sekundi nakon dostizanja praga [140 HU (HU, Hounsfield Units)].

Nakon opisanog početka skeniranje je vršeno od same trahealne bifurkacije ka dijafragmi koristeći sledeće parametre X-zračenja: cevi potencijala od 120 $\mathrm{kV}$, efektivna struja cevi $400 \mathrm{~mA}$, kolimacioni odsečak $64-0.5 \mathrm{~mm}^{2}$, brzina stola $9.2 \mathrm{~mm} /$ rotacija,i korak 0,24.

Svi skeneri su sprovedeni putem automatski implantirane anatomske dozne regulacije. Celokupno vreme skeniranja je bilo kraće od 20 sekundi, prosečno ukupno vreme trajanja pregleda je bilo oko 15 minuta.

Pri izboru optimalne faze srčanog ciklusa koristili smo se retrospektivnom EKG analizom. Za rekonstrukciju i analizu podataka je korišćen pristup kardijalnim volumenima. U zavisnosti od srčane frekvence tokom pregleda, aksijalni preseci su rekonstruisani sinhronizovano sa EKG - om, putem 
pojedinačnog sektora ili dva sektorska algoritma koristeći podatke tokom jednog ili dva konsekutivna srčana ciklusa. Povremeno je vršena manuelna repozicija shodno $\mathrm{R}$ talasnim indikatorima, kako bi se unapredila sinhronizacija.

Slike su rekontruisane u intervalima trajanja od oko $10 \%$ od srčanog ciklusa, kako bi se omogućila procena koronarnih arterija u fazama srčanih ciklusa u kojima su pokreti koronarnih arterija minimalni. Preseci su bili debljine oko o,5mm i srednji meko tkivni rekonstrukcioni kernel je korišćen radi evaluacije koronarnih arterija.

Segmenti koronarnih arterija su definisani shodno shemi (110).

Analizu nalaza su vršili lekari koji nisu bili upoznati sa anamnestičkim podacima, kao i prethodno sprovedenim dijagnostičkim procedurama. Detaljno su analizirani svi segmenti koronarnih arterija, te je procenjivana značajnost uočenih aterosklerotskih lezija, siginfikantim su smatrane stenoze $>70 \%$ luminalnog dijametra koronarne arterije.

\subsection{Transtorakalna Doppler ehokardiografska procena očuvanosti koronarne rezerve protoka po protokolu sa Adenozinom}

Ehokardiografski pregledi su urađeni na aparatu Vivid System 7, pomoću sondi od 3,5 i $7 \mathrm{MHz}$, uz aplikaciju softvera prilagođenog detekciji koronarnog protoka.

Bolesnici su postavljeni u levi lateralni dekubitalni položaj, potom su traženi najoptimalniji preseci za vizuelizaciju LAD i RCA. Aterosklerotske lezije na ACX nisu procenjivane, zbog nemogućnosti adekvatne vizuelizacije te koronarne arterije. LAD "mapping" je vršen u uzdužnom apikalnom preseku, $\mathrm{u}$ predelu sulcus interventricularis anterioris - a, dok je RCA "mapping" vršen iz apikalnog preseka 2 šupljine u predelu sulcus interventricularis 
posterioris -a. Pregledi su rađeni na malim dubinama pregleda 6-12 $\mathrm{cm}$, a detekcija koronarnog signala pomoću Color Doppler ehokardiografije i prethodno urađenog setting-a aparata za protoke malih brzina 12-20 cm/sec. Kod svih pregleda je vršena je vizuelizacija protoka u što distalnijem mogućem segmentu posmatrane koronarne arterije LAD ili RCA. Najoptimalniji presek je onaj koji je omogućio detekciju protoka pod uglom manjim od $40^{\circ}$ između linije samog protoka duž arterije i Doppler ultrazvučnog talasa.

Kod bolesnika kod kojih je prethodno izvršena revaskularizacija miokarda aorto koronarnim graftovima arterijskim ili venskim, da bi se sprečio uticaj protoka u samom graftu ili stenoza u proksimalnim delovima nativnih arterija, protok je meren u delu koronarne arterije distalno od insercije samog grafta, kako bi smo bili u mogućnosti da najrealnije procenimo i funkcionalnost samog grafta.

Nakon "mappinga" koronarnog protoka, njegove brzine su procenjivane putem Pulsnog Dopplera. Svi pregledi su sačavani u digitalnoj formi, te je omogućena i njihova nakanadna analiza.

Prvobitno su registrovane vrednosti brzina sistolnog i dijastolnog koronarnog protoka u bazalnim uslovima, potom tokom hiperemije nakon aplikacije adenozina u dozi od $0,14 \mu \mathrm{g} / \mathrm{kg}$ u toku 60 sekundi. Prosečne brzine protoka u bazalnim uslovima i tokom hiperemije su dobijene kao prosečne vrednosti tokom 3 ciklusa.

Kod svih bolesnika za vreme pregleda je kontinuirano vršen monitoring vrednosti arterijskog krvnog pritiska, kao i sam elektrokardiografski monitoring. CFR kao nedimenzionalna veličina je dobijen kao odnos između prosečne brzine koronarnog protoka pri hiperemiji i prosečne brzine koronarnog protoka u bazalnim uslovima.

Vrednosti CFR manje od 2 su razmatrane kao signifikantne vrednosti za predikciju hemodinamski značajnih stenoza, tj. stenoza $\geq 70 \%$ dijametra koronarnih arterija. 


\subsection{Invazivna koronarografija (IK)}

Invazivna koronarna agirografija je bila referentni dijagnostički metod i sprovedena shodno standardnim tehnikama i sa multiplim presecima, koji $\mathrm{su} \mathrm{u}$ digitalnoj formi sačuvani u cilju detaljnije evalauacije. Interpetaciju nalaza vršila su najmanje 2 iskusna lekara shodno AHA preporukama (110), neovisno o prethodno dobijenim rezultatima putem MSCT koronarografije i CFR-a. Signifkantnom koronarnom stenozom je smatrana aterosklerotska lezija sa redukcijom dijamtera $\geq 70 \%$. Sve dijagnostičke dileme su rešavane koncezusom između lekara.

\subsection{Statistička analiza podataka}

Statistička analiza podataka će biti izvršena u statističkom programu SPSS Inc 17.0, (Chicago, Illinois, USA).

Veličina potrebnog uzorka, najmanje 81 bolesnik, je izračunata na osnovu statističkog izračunavanja dovoljnog broja jedinica posmatranja ("sample size calculation") na osnovu pretpostavke da ce transtorakalnom ehokadiografskom procenom CFR-a broj negativnih nalaza u odnosu na rezultate MSCT koronarografije biti oko o,30. Upotrebljena je formula za izračunavanje dovoljnog broja jedinica posmatranja, za nivo verovatnoće 0,95 i preciznost 0,1 .

Korisitili smo se važećim metodama deskriptivne statisitke, parametarskim i neparametarskim testovima za poređenje rezultatata. Pearsonov koeficijent korelacije je korišćen za procenu povezanosti između pojedinih 
dijagnostičkih procedura MSCT koronarografije, ehokardiografije i invazivne koronarografije.

Za izračunavanje senzitivnosti, specifičnosti, pozitivne, negativne prediktivne vrednosti i pouzdanosti samih metoda smo upotrebljavali standardne formule. Pouzdanost tehnika je procenjivana i analizom ROC krivi, sa svim merenjima koja su prezentovana sa intervalom pouzdanosti od 95\%. Metode linearne univarijantne i multivarijantne logističke regresione analize podataka smo koristili za analizu predikativnih vrednosti pojedinih parametara u odnosu na dalji tok bolesti i pojavu neželjenih kardijalnih događaja.

Statistički značajnim rezultatima smo smatrali samo one na nivou verovatnoće od $\mathrm{p}<0,05$. 


\section{REZULTATI}

\subsection{Opšte kliničke karakteristike pacijenata uključenih u studiju}

Studija je obuhvatila 84 bolesnika, 59 (70,2\%) muškaraca, 25 žena (29,8\%), prosečne starosti od $61,8 \pm 9,2$ godine. (Tabela br. 2)

Od faktora rizika za kardiovaskularne bolesti hipertenzija je bila najzastupljenija kod 75 bolesnika (89,3\%), potom hiperlipidemija kod $71(84,5 \%)$, i pozitivno porodično opterećenje za kardiovaskularne bolesti kod 49 (58,3\%). Pušenje je bilo prisutno kod 32 (38,1\%) pacijenata, stres kod 31(36,9\%) i Diabetes mellitus $\operatorname{kod} 25$ (29,8\%).

Tabela br.2 Opšte karakteristike, faktori rizika, istorija ishemijske bolesti srca

\section{Opšte karakteristike i faktori rizika}

$\%$ (pacijenti n/84)

\begin{tabular}{ll} 
Pol muški/ženski & $59(70,2 \%) / 25(29,8 \%)$ \\
Godine starosti & $61,8 \pm 9,2$ \\
Hipertenzija & $75(89,3 \%)$ \\
Hereditet & $49(58,3 \%)$ \\
Hiperlipidemia & $71(84,5 \%)$ \\
Diabetes mellitus & $25(29,8 \%)$ \\
Pušenje & $32(38,1 \%)$ \\
Stres & $31(36,9 \%)$ \\
\hline
\end{tabular}

Istorija ishemijske bolesti srca bolesti

$\%$ (pacijenti $\mathrm{n} / 84$ )

Prethodni AIM

Prethodno PCI

Prethodno CABG
$19(22,6 \%)$

$16((19,0 \%)$

$3(3,6 \%)$

AIM akutni infarkt miokarda, PCI perkutana koronarna intervencija, CABG hiruška revaskularizacija miokarda 
Od posmatranih 84 bolesnika u momentu kada su uključeni u studiju 54 (54 tj. 64,3\%) je imalo anginozne tegobe kao prvu manifestaciju ishemijske bolesti srca, sprovedena neinvazivna kardiološka dijagnostika, uključujući i MSCT koronarografiju, je ukazivala na smanjenu koronarnu rezervu, zbog čega je i planirana dalja invazivna dijagnostika.

Prethodno dijagnostikovanu i lečenu ishemijsku bolest srca je imalo $30 \mathrm{tj}$. 35,7\% ispitanika. Ukupno 19 tj.22,6\% bolesnika je prebolovalo AIM od kojih je 8 lečeno putem primarne PCI, a 11 konvencionalno. Kod 11 tj.13,1\% bolesnika je prethodno izvršena revaskularizacija miokarda, zbog tegoba karaktera nestabilne pektoralne angine, kod 8 (9,5\%) je sprovedena elektivna PCI, a kod 3 (3,6\%) hiruška revaskularizacija miokarda. (Tabela br.2)

\subsection{Ehokardiografski i koronarografski parametri pacijenata}

MSCT koronarografija je detektovala aterosklerotske lezije različitog stepena na LAD kod 77, a na RCA kod 70 pacijenata.

Transtorakalna Doppler ehokardiografska procena koronarne rezerve protoka nije bila moguća na svim koronarnim arterijama sa detekovanim stenozama putem MSCT koronarografije iz tehničkih razloga, prevashodno lošeg kvaliteta ehokardografskog prozora.

"Feasibility“tj. izvodljivost TTDE CFR-a za LAD je bila (75/77) 97,40\%, a za RCA $(61 / 70) 87,14 \%$.

Analiza dijagnostičke vrednosti CFR-a putem Transtorakalne Doppler ehokardiografije, koronarne angiografije putem kompjuterizovane "64 slajsne“" tomografije, uz invazivnu koronarografiju kao "zlatni“ dijagnostički standard je vršena na ukupno 136 koronarnih arterija, 75 prednje descedentnih tj. LAD i 61 na desnoj koronarnoj arteriji tj. RCA. 
Transtorakalna ehokardiografska analiza je ukazala na prosečno očuvanu

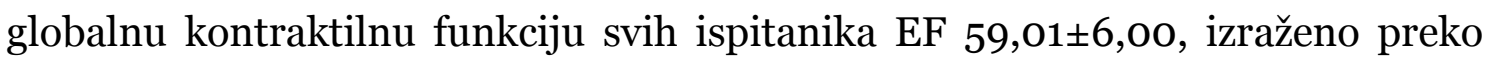
WMSI 1,04 $\pm 0,09$. Prosečna maksimalna brzina koronarnog protoka u bazalnim uslovima iznosila je za LAD:0,24 $\pm 0,22 \mathrm{~m} / \mathrm{s}$ i RCA:0,22 $\pm 0,08 \mathrm{~m} / \mathrm{s}$. Prosečna maksimalna brzina koronarnog protoka nakon aplikacije adenozina je bila za

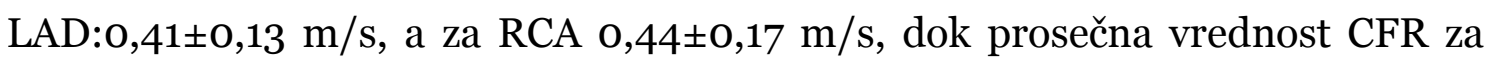
LAD je bila 2,2 $\pm 0,60$, a RCA 2,1 $\pm 0,53$.

(Tabela br.3)

Tabela br.3. Ehokardiografske karakteristike pacijenata

Ehokardiografske karakteristike pacijenata

\begin{tabular}{ll}
\hline $\mathrm{n}(84)$ & \\
$\mathrm{EF}$ & $59,01 \pm 6,00$ \\
WMSI & $1,04 \pm 0,09$ \\
LAD n(75) & \\
Vmax LAD bazalno (m/s) & $0,24 \pm 0,22$ \\
Vmax LAD adenozin(m/s) & $0,41 \pm 0,13$ \\
CFR LAD & $2,2 \pm 0,60$ \\
RCA n(61) & \\
Vmax RCA bazalno(m/s) & $0,22 \pm 0,08$ \\
Vmax RCA adenozin (m/s) & $0,44 \pm 0,17$ \\
CFR RCA & $2,1 \pm 0,53$
\end{tabular}

EF-ejekciona frakcija, WMSI-Indeks globalne pokretljivosti, LAD-prednja descedentna arterija, RCA-desna koronarna arterija Vmaxprosečna maksimalna brzina protoka, CFR-koronarna rezerva protoka

Selektivna koronarografija je kod 28 (33,3\%) detektovala jednosudovnu bolest, kod 13 (15,5\%) dvosudovnu i kod 6 (7,1\%) bolesnika trosudovnu koronarnu bolest. Kod 25 (29,8\%) pacijenata promene su bile lokalizovane na LAD, kod 18 $(21,4 \%)$ na ACX i kod 29 (34,5\%) na RCA. Izražen torutuozitet koronarnih arterija je opisan kod $13(15,5 \%)$ pacijenata, a prisustvo kolaterala kod 23 $(27,4 \%)$ ispitanika. 
Tabela br.4 Koronarografske karakteristike pacijenata

Koronarografske karakteristike pacijenata $(n=84)$

\begin{tabular}{lc} 
Br.obolelih korornarnih arterija & \\
o & \\
1 & $37(44,0 \%)$, \\
2 & $28(33,3 \%)$, \\
3 & $13(15,5 \%)$, \\
LAD & $6(7,1 \%)$ \\
ACX & $25(29,8 \%)$ \\
DCA & $18(21,4 \%)$ \\
tortuozitet & $29(34,5 \%)$ \\
Kolaterale & $13(15,5 \%)$ \\
\hline
\end{tabular}

LAD-prednja descedentna arterija, ACX cirkumfeleksna arterija, RCA-desna koronarna arterija

4.3. Procena dijagostičke vrednosti MSCT koronarografije i TTDECFR pri proceni postojanja HD značajnih aterosklerotskih lezija na LAD, uz invazivnu koronarografiju kao referentni metod

Invazivna koronarografija je detektovala na LAD značajne aterosklerotske lezije kod 25 (33,33\%) bolesnika, MSCT koronarografija kod 47 (62,70\%), a TTDE procena CFR-a kod 28 (37,33\%). Poređenjem rezultata sve tri tehnike putem Cochran-ovog Q testa uočena je statistički značajna razlika između pomenutih tehnika $(\mathrm{p}<0,001)$ pri detekciji signifikantih stenoza na LAD. Dodatna analiza razlike između pojedinačnih tehnika putem Mc Nemar-ovih testova je pokazala statistički značajnu razliku između rezultata invazivne i neinvazivne 
koronarografije $(\mathrm{p}<0,01)$, kao i između neinvazivne koronarografije i TTDECFR-a $(p<0,01)$, dok između invazivne koronarografije i TTDE-CFR-a nije dobijena statistički značajna razlika $(\mathrm{p}=0,45)$. (Tabela br.5) (Slika br.9)

Tabela br.5 Poređenje rezultata koronarografije, MSCT koronarografije i TTDE-CFR-a pri dijagnostikovanju značajnih aterosklerotskih lezija na LAD

\begin{tabular}{ccccl}
\hline $\begin{array}{l}\text { Hemodinamski } \\
\text { značajne stenoze }\end{array}$ & Koronarografija & $\begin{array}{c}\text { MSCT } \\
\text { koronarografija }\end{array}$ & $\begin{array}{c}\text { Koronarna } \\
\text { rezerva protoka }\end{array}$ & Cochran's Q - \\
\hline $\begin{array}{c}\text { Koronarna arterija } \\
\text { LAD (n=75) }\end{array}$ & $25 / 75$ & $47 / 75$ & $28 / 75$ & 27,55 \\
& $(33.33 \%)$ & $(62.70 \%)$ & $(37.33 \%)$ & $\mathrm{p}<0,001$ \\
Mc Nemar testovi & & + & + & $\mathrm{p}<0,001$ \\
razlike između & + & + & + & $\mathrm{p}<0,001$ \\
pojedinih tehnika & + & & & $\mathrm{p}=0,453$ \\
\hline
\end{tabular}

Korelaciona analiza nalaza na LAD je ukazala na najznačajniju povezanost između nalaza invazivne koronarografije i TTDE-CFR-a ( $\mathrm{r}-0,653, \mathrm{p}<0,001)$, kao i značajnu povezanost između invazivne i MSCT koronarografije ( $\mathrm{r}$ o,445, $\mathrm{p}<0,001)$. Najslabija povezanost je uočena između MSCT koronarografije i TTDE- CFR-a (r -0,236,p<0,05) (Slika br.9) 


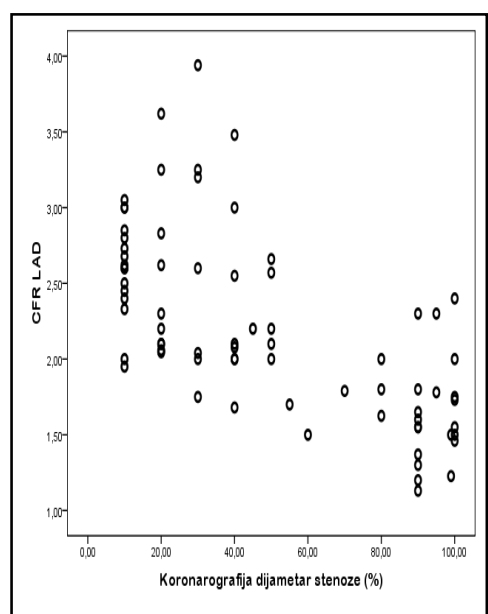

A

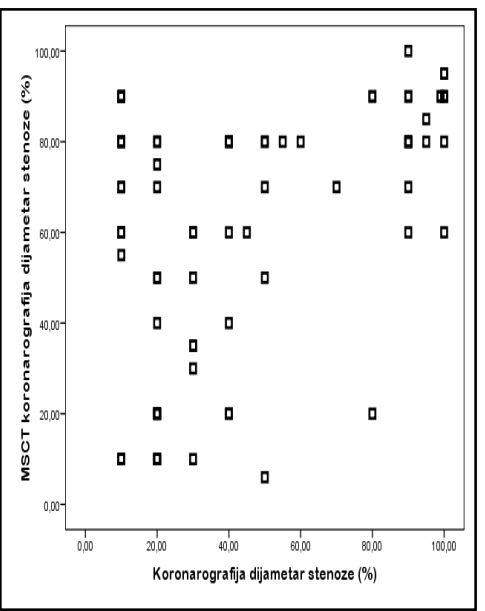

B

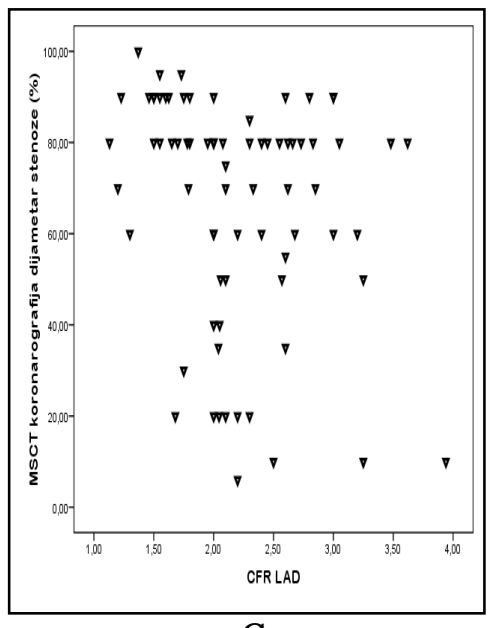

C

Slika br.9. Korelacije (LAD) a)invazivne koronarografije i TTDE-CFR-a; b) invazivne koronarografije i MSCT koronarografije i c) MSCT koronarografije i TTDE- CFR-a

Signifikante stenoze $(\geq 70 \%)$ na $\mathrm{LAD}$ su detektovane invazivnom koronarografijom na 25 od 75, (33,33\%), intermedijarne lezije (50-70\%) na 7 od 75 (9,33\%), a nesignifikante promene $(<50 \%)$ na 43 od 75 (57,33\%) arterija.

MSCT je verifikovala 47 opstruktivne promene na LAD (62,70\%), 22 od 47 $(46,81 \%)$ su bile značajne i putem konvencionalne koronarografije, dok je 25 od 47 (53,11\%) opstruktivnih lezija putem MSCT koronarografije bilo precenjeno u poređenju sa invazivnom koronarografijom. MSCT je verfikovala 12 od 75 $(16,00 \%)$ stenoza intermedijarnog značaja, 10 od 12 (83,33\%) su bile precenjene promene. MSCT je detektovala i 16 of 75 (21,33\%) LAD kao arterije sa nesignifkantnim promenama ( $<50 \%)$, kod 13 od $16(81,25 \%)$ nalazi su bili u saglasnosti sa invazivnim merenjima. (Slika 10.C) 
Analizom nalaza TTDE CFR-a i MSCT koronarografije (Slika 10.A.) pri detekciji signifikantnih lezija uočena je njihova podudarnost samo kod 24 od 47 (51.06\%) LAD arterija, dok kod 23 od 47 (48.94\%) opstruktivno promenjenih LAD arterija na MSCT smo imali očuvanu koronarnu rezervu protoka, koja je praktično isključivala njihov hemodinamski značaj. Razmatrajući intermedijarne lezije detektovane putem MSCT-a, koronarna rezerva protoka je bila očuvana kod 11 od 12 (91,67\%) arterija isključujući njihov funkcionalni značaj. Razmatrajući normalne nalaze na LAD putem MSCT koronarografije saglasnot sa CFR-om je bila kod 13 od 16 (81.25\%) LAD arterija.

TTDE CFR merenja su detektovala kod 28 od 75 (37,33\%) LAD arterija hemodinamski signifikantne $(\mathrm{CFR}<2)$ stenoze, i rezultati su bili u saglasnosti sa nalazima na invazivnoj koronarografiji kod 23 od 28 (82,14\%) LAD arterije, dok $5(17,86 \%)$ LAD nije imalo signifikantne aterosklerotske lezije na invazivnoj koronarografiji. TTDE CFR je kod 47 od 75 (62,67\%) LAD arterija uočila očuvanu koronarnu rezervu protoka, i kod 40 of $47(85,11 \%)$ LAD arterija nalazi su bili podudarni sa invazivnom koronarografijom, ali kod 7 od $47(14,89 \%)$ smo imali značajne promene na koronarografiji, stim što su 5 od 7 bile intermedijarne lezije najverovatnije sa još očuvanom koronanrom rezervom protoka i 2 sa signifikatnim promenama. (Slika br 10.B) 


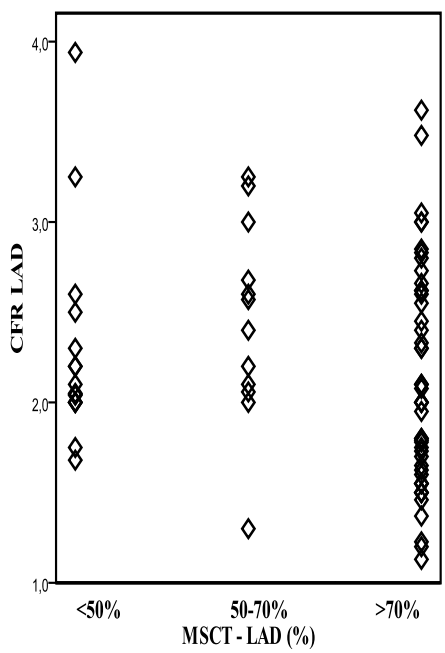

A

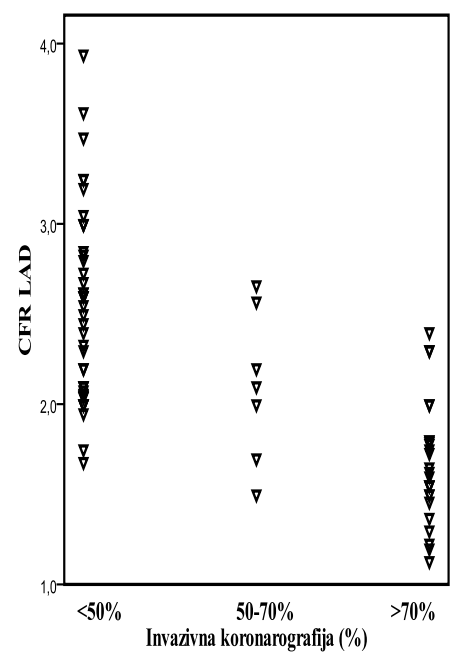

B

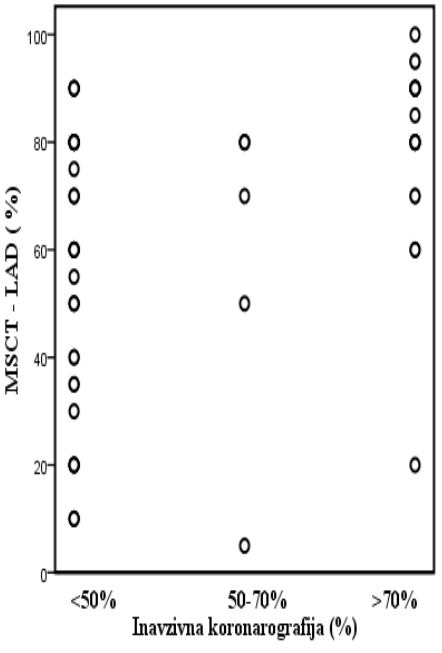

$\mathrm{C}$

Slika br. 10. Odnos nesignifikantnih, interemedijarnih i signifikantnih stenoza registrovanih na LAD putem TTDE - CFRa, MSCT i invazivne koronarografije:

a) odnos vrednosti TTDE-CFR a u odnosu na nesignifikantne, interemedijarne i signifikantne stenoze LAD detektovane MSCT koronarografijom; b) odnos vrednosti TTDE-CFR a u odnosu na nesignifikantne, interemedijarne i signifikantne stenoze LAD detektovane invazivnom koronarografijom;c) odnos stenoza registrovanih putem MSCT koronarografije u odnosu na u odnosu na nesignifikantne, interemedijarne i signifikantne stenoze LAD detektovane invazivnom koronarografijom 
Statistička analiza ROC krive je ukazala na značajnu ulogu CFR-a pri detekciji opstruktivnih promena na LAD (Area 0,91,SE 0,036, p<0,001), vrednosti $\mathrm{CRF}<2,02$ su imale senzitivnost $88,0 \%$ i specifičnost $80,0 \%$. (Slika br.11)

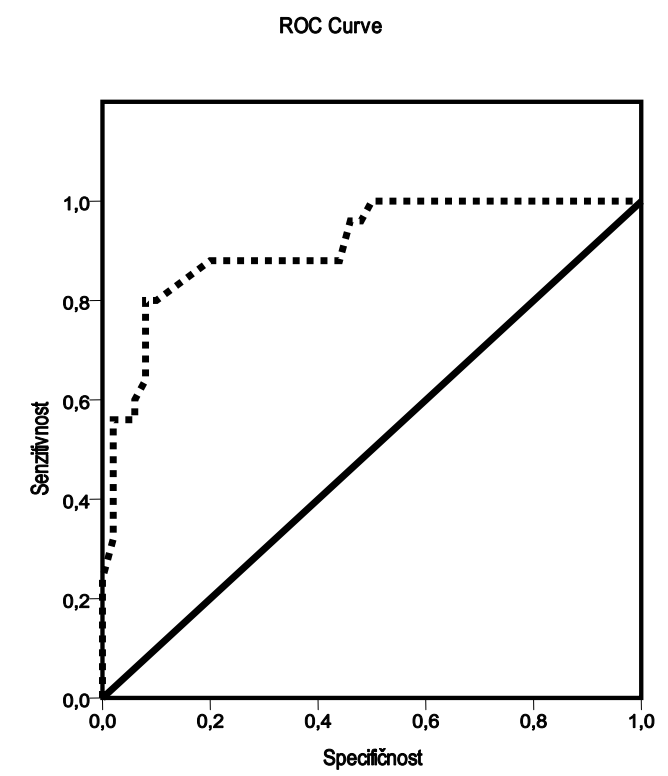

Slika br.11. Senzitivnost i specifičnost CFR a pri detekciji opstruktivnih lezija na LAD

Statistička analiza pomoću ROC krive je ukazala na signifikantnu ulogu MSCT koronarografije pri detekciji opstruktivnih promena na LAD (Area 0,82, SE o,048, p<0,001), a stenoze dijametra $72,5 \%$ su imale senzitivnost $80,0 \%$ i specifičnost $64,4 \%$.(Slika br.12) 


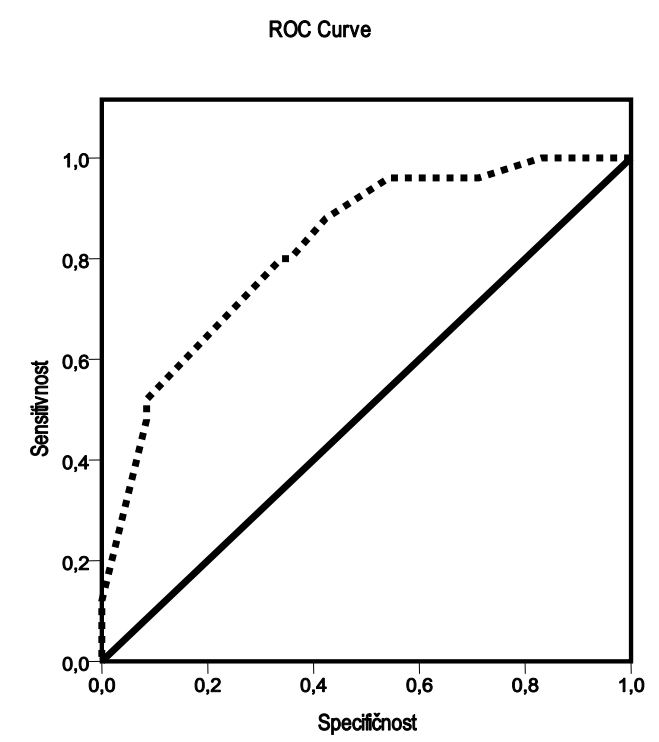

Slika br 12. Senzitivnost i specifičnost MSCT koronarografije pri detekciji opstruktivnih lezija na LAD

Poređenjem ROC krivi MSCT koronarografije i CFR -a nije uočena statistički značajna razlika Z -1,467, p o,143, (razlika između area o,o88, SE o,o6).

Procena dijagnostičke vrednosti tehnika standardnim jednačinama je ukazala da je neinvazivna koronarografija pri detekciji stenoza dijametra većeg od 70\% na LAD, uzimajući nalaze invazivne koronarografije kao referentne vrednosti imala senzitivnost $88,0 \%$, specifičnost $57,6 \%$, pozitivnu predikativnu vrednost $46,8 \%$ i negativnu predikativnu vrednost $91,19 \%$, dok je pouzdanost iznosila $66,7 \%$.

TTDE procena CFR-a na LAD je imala senzitivnost 92,0\%, specifičnost 90,0\%, pozitivnu predikativnu vrednost $82,1 \%$ i negativnu predikativnu vrednost $95,74 \%$, a pouzdanost $97,3 \%$. 
Kada su kao stvarno značajne lezije razmatrane samo one kod kojih su obe tehnike ukazivale na značajnost promena, imali smo značajan porast specifičnosti, pozitivne predikativne vrednosti i dijagnostičke pozdanosti do $97,33 \%$, dok su senzitivnost i negativna predikativna vrednost ostale neznatno izmenjene. (Slika br.13)

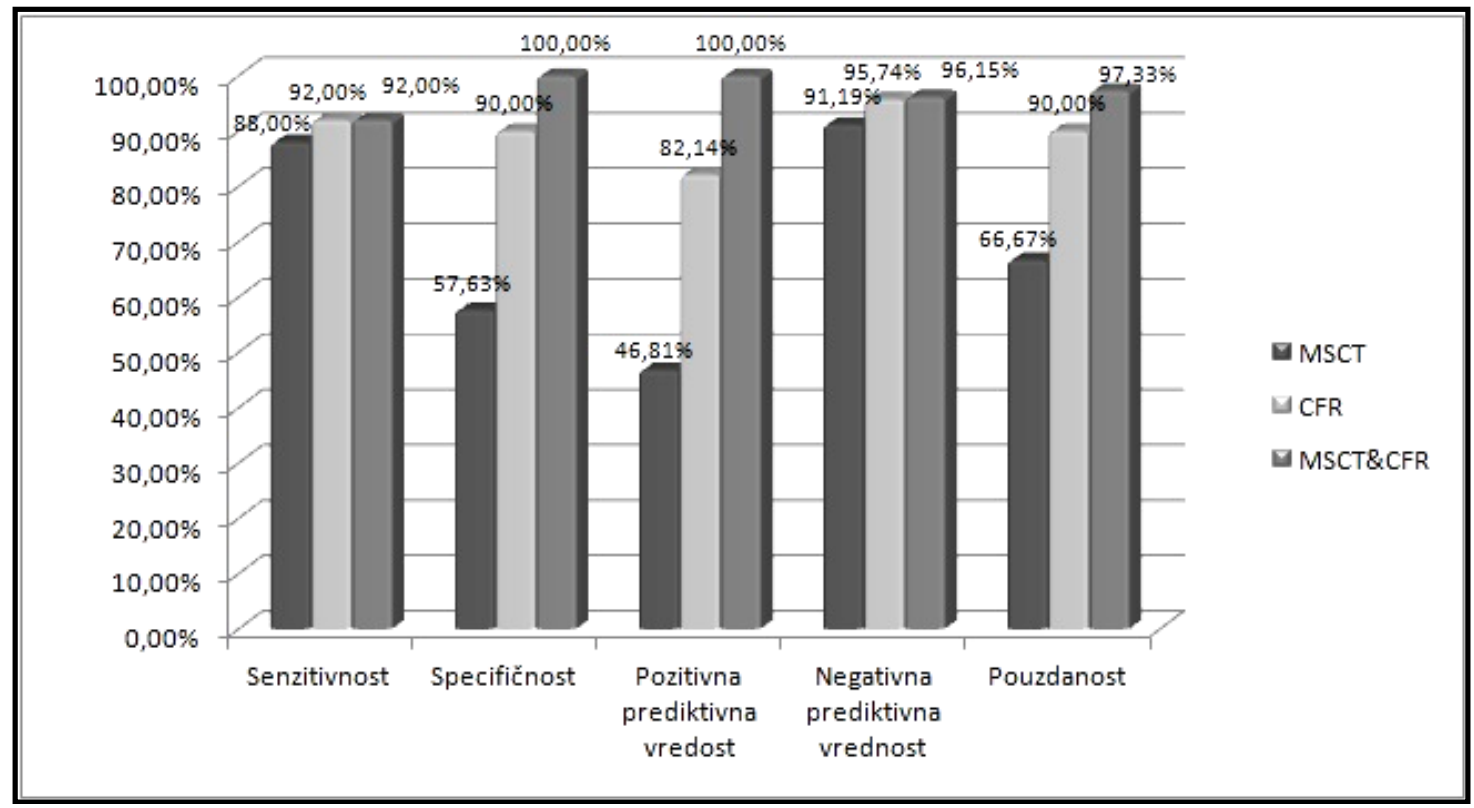

Slika br.13 Dijagram dijagnostičkih parametara MSCT koronarografija i TTDE-CFR-a pojedinačno, i pri zajedničkom razmatranju nalaza na LAD 


\subsection{Procena dijagostičke vrednosti MSCT koronarografije i TTDE- CFR-a pri proceni postojanja HD značajnih aterosklerotskih lezija na RCA, uz invazivnu koronarografiju kao referentni metod}

Invazivna koronarografija je detektovala značajne stenoze na RCA, dijametra većeg od 70\%, kod 26 (42,62\%) bolesnika, MSCT koronarografija kod 40 (65,57\%), a TTDE procena CFR-a kod 26 (42,62\%) Poređenjem rezultata sve tri tehnike putem Cochran-ovog $Q$ testa uočena je statistički značajna razlika pri detekciji signifikantih stenoza između pomenutih tehnika $(\mathrm{p}<0,006)$. Dodatna analiza razlike između pojedinačnih tehnika putem Mc Nemar-ovih testova je uočila statistički značajnu razliku između rezultata invazivne koronarografije i MSCT koronarografije ( $\mathrm{p}<0,01$ ), kao i između MSCT koronarografije i TTDECFR-a $(p<0,01)$, dok između invazivne koronarografije i TTDE-CFR-a nije zapažena statistički značajna razlika $(\mathrm{p}=1)$. (Tabela br.6)(Slika br.14)

Tabela br.6 Poređenje rezultata koronarografije, MSCT koronarografije i TTDE-CFR-a pri dijagnostikovanju značajnih aterosklerotskih lezija na RCA

\begin{tabular}{|c|c|c|c|c|}
\hline $\begin{array}{l}\text { Hemodinamski } \\
\text { značajne stenoze }\end{array}$ & Koronarografija & $\begin{array}{c}\text { MSCT } \\
\text { koronarografija }\end{array}$ & $\begin{array}{l}\text { Koronarna } \\
\text { rezerva } \\
\text { protoka }\end{array}$ & Cochran's Q - \\
\hline $\begin{array}{l}\text { Koronarna arterija } \\
\text { RCA }(n=61)\end{array}$ & $\begin{array}{c}26 / 61 \\
(42,62 \%)\end{array}$ & $\begin{array}{c}40 / 61 \\
(65,57 \%)\end{array}$ & $\begin{array}{c}26 / 61 \\
(42,62 \%)\end{array}$ & $\begin{array}{l}10,23 \\
p<0,006\end{array}$ \\
\hline $\begin{array}{l}\text { Mc Nemar testovi } \\
\text { razlike između } \\
\text { pojedinih tehnika }\end{array}$ & $\begin{array}{l}+ \\
+\end{array}$ & $\begin{array}{l}+ \\
+\end{array}$ & $\begin{array}{l}+ \\
+\end{array}$ & $\begin{array}{l}\mathrm{p}<0,023 \\
\mathrm{p}<0,007 \\
\mathrm{p}=1,000\end{array}$ \\
\hline
\end{tabular}


Analiza korelacija između pomenutih tehnika je ukazala na značajnu povezanost između koronarografije i CFR-a ( $\mathrm{r}-0,560, \mathrm{p}<0,001)$, kao i između koronarografije i MSCT koronarografije (r 0,566, p<0,001) i najmanji stepen povezanosti je uočen između neivazivne koronarografije i CFR-a (r -0,222,p o,o86). (Slika br.14)

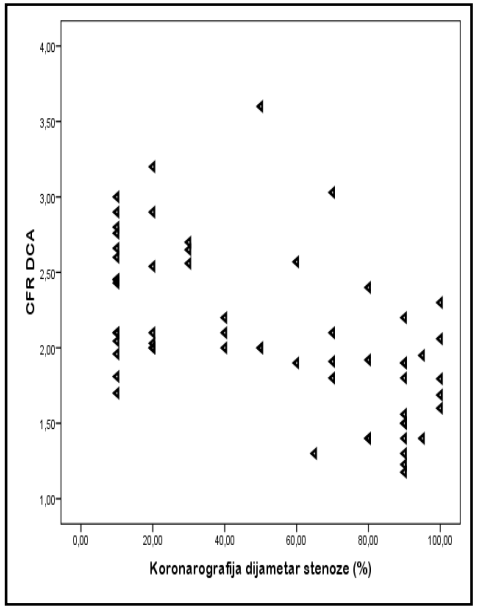

A

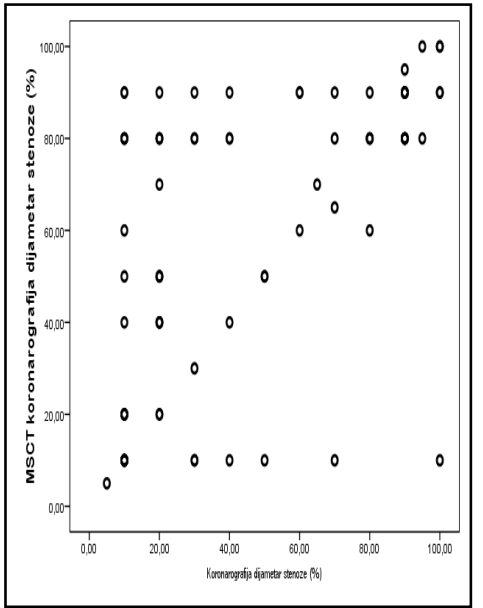

B

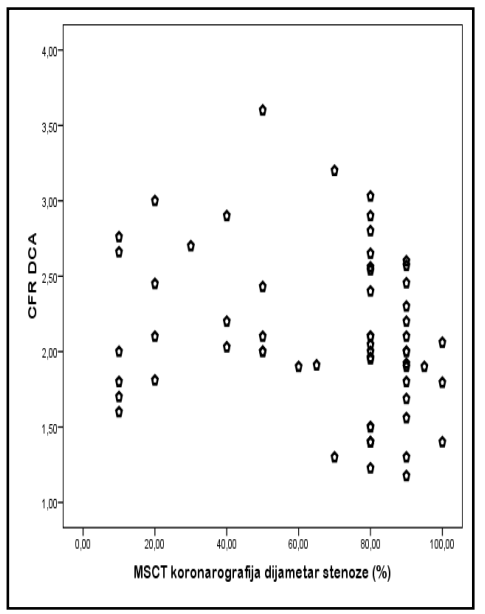

C

Slika br.14 Korelacije (RCA): a)invazivne koronarografije i TTDE-CFR-a; b) invazivne koronarografije i MSCT koronarografije i c) MSCT koronarografije i TTDE- CFR-a

Konvencionalna koronarografija je detektovala kod 26 od 61 (42, 62\%) RCA arterija signifikantne stenoze, kod 6 od 61 (9,83\%) intermedijarne lezije i kod 29 od $61(47,54 \%)$ ne signifikantne promene.

MSCT koronarografija je dijagnostikovala opstruktivne aterosklerotske lezije kod 40 od 61 (65,57\%) RCA arterije, kod 17 od 40 (42,50\%) smo imali precenjene promene $\mathrm{u}$ poređenju sa invazivnom koronarografijom ( $2 \mathrm{su}$ bile 
intermedijarne i 15 nesignifikantne na konvencionalnoj koronarografiji). Razmatrajući lezije intermedijarnog dijametra MSCT je detektovala 7 od 61 $(11,48 \%)$, ali su 3 od $7(42,86 \%)$ bile precenjene. Neinvazivna koronarografija je detektovala kod 14 od 61 (22,95\%) RCA arterija nesignifkantne promene, što je bilo u saglasnosti sa nalazima konvencionalne koronarografije kod 11 od 14 (78,57\%) bolesnika.(Slika br.15 C)

Analizom merenja TTDE-CFR-a i MSCT koronarografije (Slika 15.A) saglasnost pri detekciji signifikantnih lezija je postojala kod 20 od 40 (50,00\%), dok je 20 od 40 (50,00\%) imalo očuvanu koronarnu rezervu protoka. Analizirajući intermedijarne lezije putem MSCT koronarografije, očuvana koronarna rezerva protoka je bila prisutna kod 5 od 7 (71,43\%) RCA arterije, što je isključivalo njihov hemodinamski značaj. Razmatrajući nesignifikantne lezije na MSCT koronarografiji saglasnost među tehnikama je bila prisutna kod 10 od 14 $(71,43 \%)$ RCA arterija.

TTDE -CFR procene su kod 26 od $61(42,62 \%)$ RCA arterije detektovale funkcionalno značajne promene što je bilo u saglasnosti kod 20 od 26 (76,92\%), dok kod 6 od 26 (23,08\%) smo imali precenjene rezultate u odnosu na konvencionalnu koronarografiju ( 2 arterije su imale intermedijarne lezije i 4 nesignifikantne). TTDE procena CFR-a je detektovala normalan koronarni protok kod 35 od $61(57,38 \%)$ RCA arterije, saglasnost sa invazivnom koronarografijom je bila prisutna kod 25 od 35 (71,43\%) arterija. Iako 10 od 35 $(28,57 \%)$ su bile podcenjene, većina tih arterija 6 do 10 je imala na konvencionalnoj kronarografiji lezije intermedijarnog ranga, koje su najverovatnije i bile funkcionalno kompetentne (Slika 15.B ) 


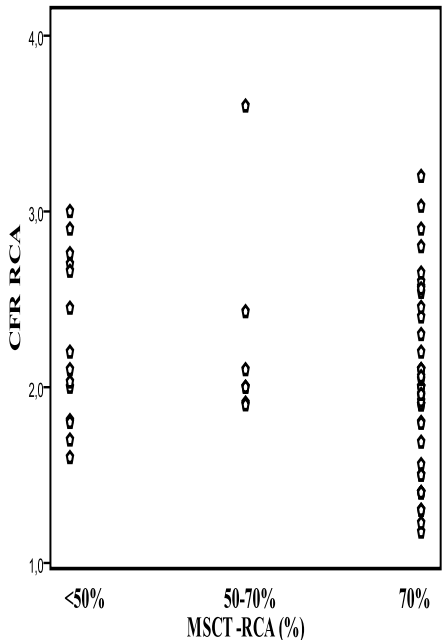

A

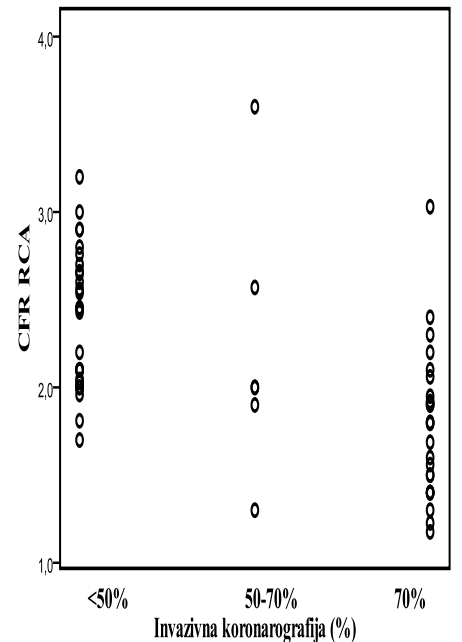

B

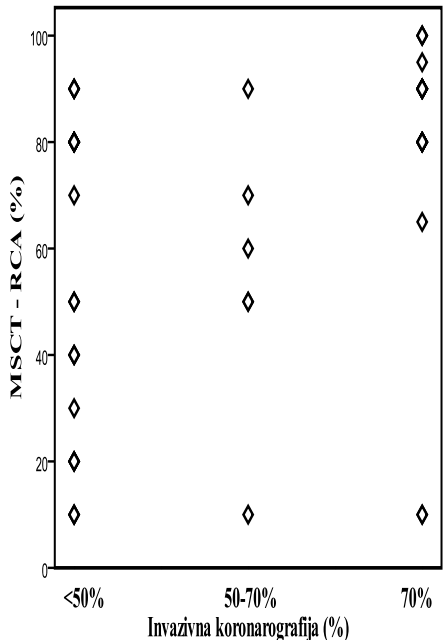

$\mathrm{C}$

Slika br. 15. Odnos nesignifikantnih, interemedijarnih i signifikantnih stenoza registrovanih na RCA putem TTDE - CFRa, MSCT i invazivne koronarografije:

a) odnos vrednosti TTDE-CFR a u odnosu na nesignifikantne, interemedijarne i signifikantne stenoze RCA detektovane MSCT koronarografijom; b) odnos vrednosti TTDE-CFR-a u odnosu na nesignifikantne, interemedijarne i signifikantne stenoze RCA detektovane invazivnom koronarografijom;c) odnos stenoza registrovanih putem MSCT koronarografije u odnosu na $u$ odnosu na nesignifikantne, interemedijarne i signifikantne stenoze RCA detektovane invazivnom koronarografijom 
Statistička analiza ROC krivi je ukazala na značajnu ulogu CFR-a pri detekciji opstruktivnih promena na RCA (Area 0,84,SE 0,055, p<0,001), detektovane vrednosti CRF <2,02 na RCA su imale senzitivnost $76,9 \%$ i specifičnost 68,6\%.(Slika br.16)

ROC Curve

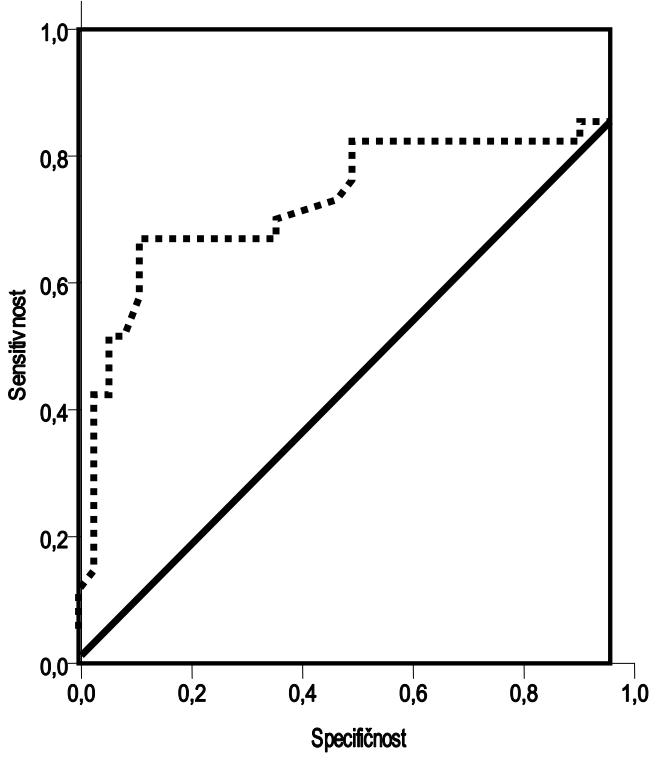

Slika br.16. Senzitivnost i specifičnost CFR a pri detekciji opstruktivnih promena na RCA

Statistička analiza ROC krivi je ukazala na signifikantnu ulogu MSCT koronarografije pri detekciji opstruktivnih promena na RCA (Area o,81,SE o,050, p<0,001), detektovane lezije dijametra $67,5 \%$ su imale senzitivnost $86 \%$ i specifičnost $63,6 \%$. (Slika br.17) 


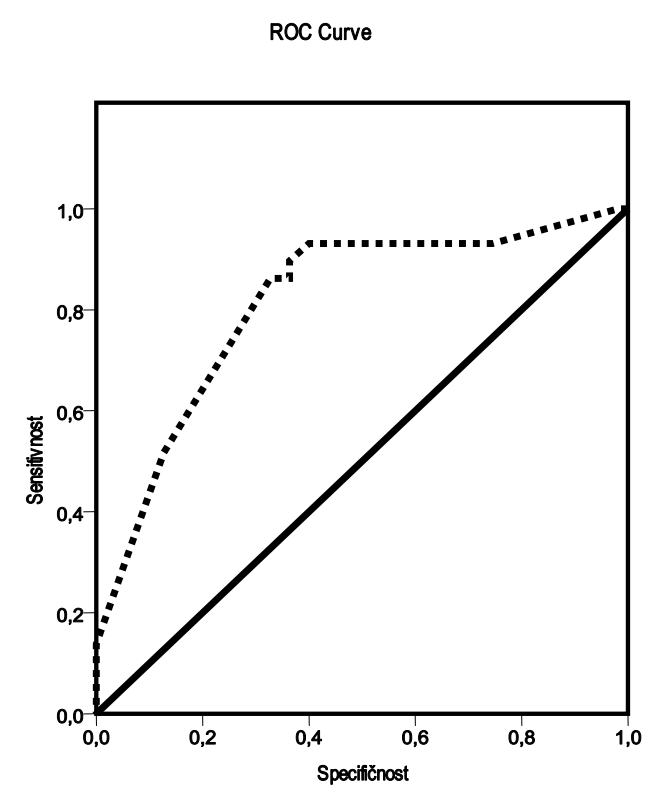

Slika br.17. Senzitivnost i specifičnost MSCT koronarografije pri detekciji opstruktivnih promena na RCA

Poređenjem ROC krivi MSCTkoronarografije i CFR a nije uočena statistički značajna razlika Z -0,323, p 0,747, (razlika između area - 0,024, SE 0,07)

Analiza dijagnostičke vrednosti tehnika standardnim jednačinama je ukazala da je MSCT koronarografija pri detekciji stenoza dijametra većeg od 70\% na RCA, uzimajući rezultate invazivne koronarografije kao referentne imala senzitivnost $86,2 \%$, specifičnost $69,1 \%$, pozitivnu predikativnu vrednost $59,5 \%$ i negativnu predikativnu vrednost 90,4\% i pouzdanost 75,0\%.

TTDE procena CFR-a na RCA je imala senzitivnost $76,9 \%$, specifičnost $85,3 \%$, pozitivnu predikativnu vrednost $80,00 \%$ i negativnu predikativnu vrednost $82,9 \%$, a pouzdanost $81,7 \%$. 
Kada su kao stvarno značajne lezije razmatrane samo one kod kojih su obe tehnike ukazivale na značajnost, imali smo značajan porast specifičnosti, pozitivne predikativne vrednosti i dijagnostičke pozdanosti do 90,0\%, dok su senzitivnost, negativna predikativna vrednost bile neznatno izmenjene (Slika br.18).

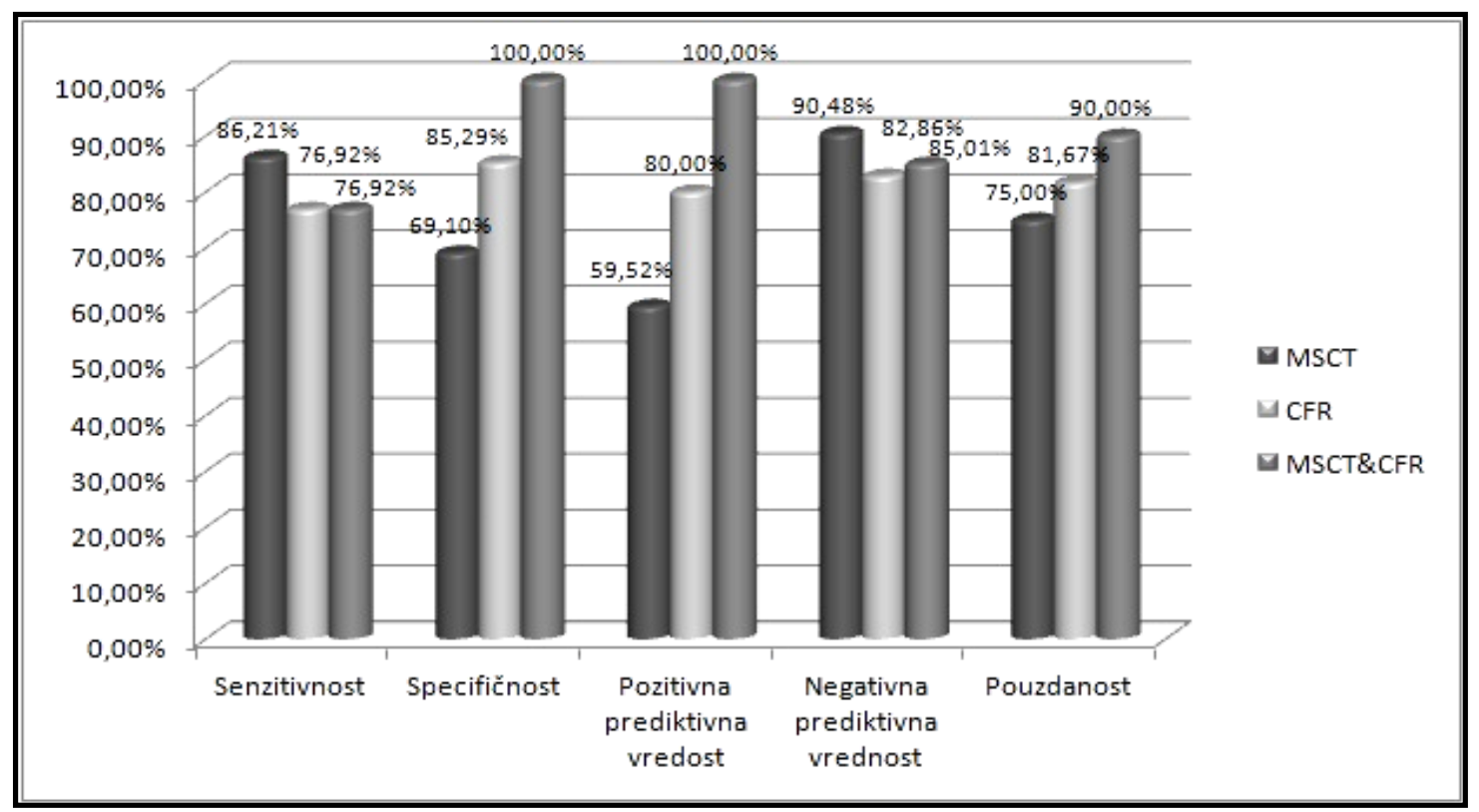

Slika br. 18. Dijagram dijagnostičkih parametara MSCT koronarografije i TTDE-CFR-a pojedinačno, i pri zajedničkom razmatranju rezultata 


\subsection{Prognostička vrednost koronarne rezerve protoka određene putem TTDE kod bolesnika sa prethodno verfikovanim lezijama putem MSCT koronarografije u odnosu na pojavu neželjenih}

kardiovaskularnih događaja u periodu praćenja

U toku šestomesečnog praćenja među posmatranim bolesnicima nije bilo letalnih ishoda ni novih akutnih koronarnih događaja. Na osnovu sprovedene dijagnostike 44 bolesnika je nastavilo lečenje medikamentoznom terapijom, dok je kod 40 bolesnika sprovedena revaskularizacija miokarda. Revaskularizacija miokarda putem PCI izvršena je kod 26 bolesnika, a kod 14 putem koronarne hirurgije.

Kada smo podelili posmatrane bolesnike na one sa sniženom i očuvanom koronarnom rezervom i posmatrali dalji tok bolesti i lečenja, uočeno je da je značajno češća učestalost opstruktivnih promena, samim tim indikacija i za revaskularizaciju bila kod bolesnika sa sniženom koronarnom rezervom protoka (Tabela br. 7)

Tabela br. 7. Dalji tok bolesti u toku šestomesečnog praćenja

\begin{tabular}{|c|c|c|c|c|}
\hline $\begin{array}{l}\text { Dalji tok } \\
\text { bolesti }\end{array}$ & $\begin{array}{l}\text { Medikamentozna } \\
\text { terapija }\end{array}$ & $\begin{array}{l}\text { Revaskularizacija } \\
\text { miokarda PCI }\end{array}$ & $\begin{array}{l}\text { Revaskularizacija } \\
\text { miokarda } \\
\text { hirurgija }\end{array}$ & \\
\hline CFR LAD $<2$ & $4 \%, 3 / 75$ & $16 \%, 12 / 75$ & $17,33 \%, 13 / 75$ & $\begin{array}{l}X^{2} 33,60 \\
p<0,00\end{array}$ \\
\hline CFR LAD > 2 & $45,33 \%, 34 / 75$ & $16 \%, 12 / 75$ & $1,33 \%, 1 / 75$ & \\
\hline CFR RCA <2 & $9,84 \% 6 / 61$ & $18,03 \%, 11 / 61$ & $\begin{array}{l}14,75 \%, 9 / 61 \\
0 \%, 0 / 61\end{array}$ & $\begin{array}{l}X^{2} 23,30 \\
p<0,00\end{array}$ \\
\hline
\end{tabular}


Regresiona analiza je obuhvatila nekoliko prediktora: hipertenziju, hiperlipidemiju, stres, pušenje, hereditet za KVB, Diabetes mellitus, dijametar stenoze procenjen putem MSCT na LAD i RCA, i CFR određen putem TTDE na LAD i RCA, kao i priusutvo kolateralne koronarne cirkulacije. Multivarijantna regresiona analiza prediktora težine bolesti i daljeg toka lečenja medikamentoznom ili revaskularizacionom terapijom je ukazala da je koronarna rezerva protoka procenjenja na $\operatorname{LAD}(p=0,016)$ i $\mathrm{RCA}(\mathrm{p}=0,007)$ bila najznačajniji prediktor daljeg toka lečenja i terapije. (Tabela br 8).

Tabela br. 8. Multivarijantna regresiona analiza prediktora daljeg toka bolesti i lečenja

\begin{tabular}{lcccc}
\hline Varijable & B & S.E. & df & Sig. \\
\hline Hipertenzija & 0,637 & 4,374 & 1 & 0,884 \\
Hiperlipidemia & $-2,051$ & 1,361 & 1 & 0,132 \\
Hereditet & 0,072 & 0,973 & 1 & 0,941 \\
Pušenje & $-0,796$ & 1,130 & 1 & 0,481 \\
Diabetes mellitus & 1,790 & 1,152 & 1 & 0,120 \\
Stres & 2,030 & 1,249 & 1 & 0,104 \\
MSCT LAD & $-0,009$ & 0,019 & 1 & 0,620 \\
MSCT RCA & 0,024 & 0,019 & 1 & 0,210 \\
CFR LAD & 3,355 & 1,390 & 1 & $\mathbf{0 , 0 1 6}$ \\
CFR RCA & 3,742 & 1,383 & 1 & $\mathbf{0 , 0 0 7}$ \\
Kolaterale & $-1,505$ & 1,198 & 1 & 0,209 \\
\hline
\end{tabular}




\section{DISKUSIJA}

Invazivna koronarnarografija iako referentna tehnika tkz. "zlatni standard“ pri dijagnostikovanju koronarne bolesti, predstavlja luminogram, odnosno dvodimenzionalni prikaz trodimenzionalnog vaskularnog lumena. Angiografski nalazi značajanost stenoza interpretiraju najšeće kao dijametar minimalnog lumena $\mathrm{u}$ odnosu na preostale normalne, odnosno neizmenjene segmente koronarnih arterija. Pouzdanost ovakvih nalaza je uvek limitirana zbog otežane distinkcije između neizmenjenog i obolelog segmenta koronarne arterije, posebno kod postojanja difuzne koronarne bolesti (52). Koronarografski prikazi nam ne omogućavaju uvid u samu strukturu vaskularnog zida, te time ni u sastav, dužinu i ekcscentričnost aterosklerotskog plaka. Ekscentrično izmenjen lumen koronarne arterije je izuzetno teško precizno proceniti, jer prikaz samog plaka i njegovog efekta na lumen i koronarni protok zavisice od ugla snimanja i dobijenog preseka koronarne arterije. (Slika br.19)

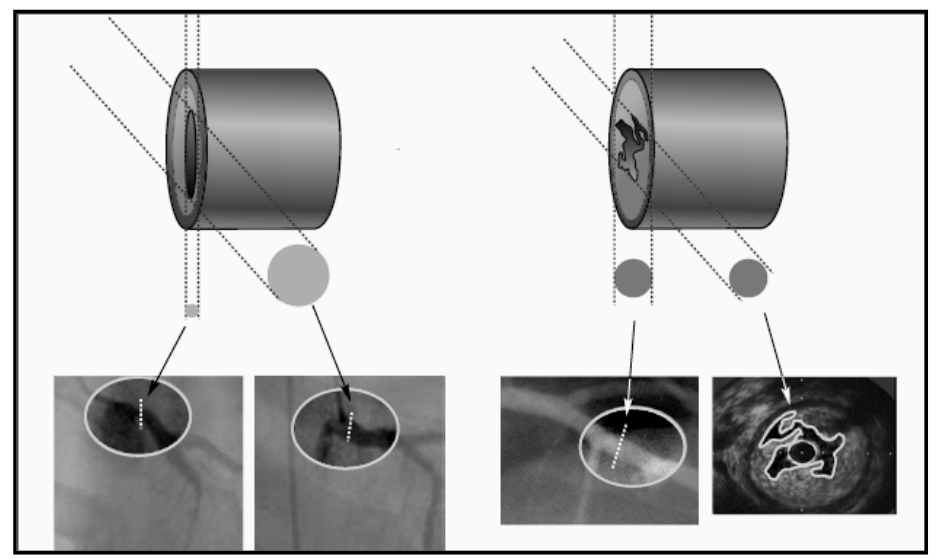

Slika br. 19. Dvodimenzionalni prikaz trodimenzionalnog vaskularnog lumena; (Kern J.Morton, and Samady Habib. Current Concepts of Integrated Coronary Physiology in the Catheterization Laboratory J. Am. Coll. Cardiol. 2010;55;173) 
Duge tkz. tubularne stenoze intermedijarnog stepena često imaju hemodinamski značajnije posledice u odnosu na kratke, fokalne tkz. anularne stenoze težeg stepena. Interpretaciju nalaza često otežava i sam protok kontrasta, senke okolnih arterija, njihovih bifurkacija i grana, kalcifikacije, ostijalna lokalizacija (111).

Nakon prezentovanja saznanja od strane Glagov-a i saradnika (112) o fenomenu vaskularnog remodelovanja, odnosno eksternog, adventicijalnog zadebljanja zida koronarne arterije usled ateroma, zaključeno je da i pored odsustva suženja koronarog lumena postoji značajan rizik od njihove rupture i nastanka akutnih koronarnih dogođaja (112). Veliki broj histopatoloških studija je ukazao i na značajnu diskrepancu između angiografski procenjene težine aterosklerotske lezije i histoloških post mortem analiza (114). Studije sa funkcionalnim testovima prezentuju podatke o diskrepanci između težine angiografskih nalaza $\mathrm{i}$ ishemije (41).

Uprkos pokušajima evaluacije kompleksne koronarne anatomije sa multiplim projekcijama tokom snimanja, samo vizuelna procena težine koronarne stenoze često ne daje realan uvid u hemodinamski značaj lezije (115). Poslednjih nekoliko godina rezultati velikih prospektivnih studija DEFER (117), COURAGE (118), FAME (119) ukazuju da je revaskularizacija miokarda determinisana funkcionalnim značajem stenoza, procenjenim putem putem Intrakoronarnog Doppler katetera za procenu frakcione rezerve protoka (FFR) je rezultovala smanjenjem mortaliteta, neželjenih kardijalnih događaja, kao i troškova lečenja.

Postojeća saznanja ukazuju na neophodnost kako morfološke tako i funkcionalne procene aterosklerotskih lezija u cilju dobijanja pouzdanih i preciznih odrednica u primeni dalje dijagnostike, terapije i samim tim unapređenja i prognoze koronarne bolesti. 


\subsection{Dijagnostička pouzdanost MSCT koronarografije pri detekciji koronarne okluzivne bolesti}

Koronarna angiografija putem 64-"slajsne" kompjuterizovane tomografije je neinvazivna dijagnostička tehnika sa mogućnošću vizuelizacije celog koronarnog stabla i visoke djagnostičke pouzdanosti pri detekciji opstruktivnih promena.

Nekoliko studija iskusnih centara prezentovali su podatke o dijagnostičkoj pouzdanosti 64-"slajsne" MSCT koronarografije u kojima se senzitivnost se kretala između 83 i 99\%, a specifičnost od 93 do $98 \%$ pri detekciji okluzivnih lezija, definisanih kao redukcija lumena koronarne arterije veća od 50\%, Procenat neinterpretabilnih koronarnih segmenata je bio između o i $12 \%$. Većina studija je referisala visoku negativnu predikativnu vrednost između $95 \mathrm{i}$ $100 \% .(62,63,64,82-, 84)$

Leschka i saradnici su prezentovali analizu svojih rezultata u odnosu na koronarne arterije pojedinačno i rezultati su bili komparabilni za LAD senzitivnost 93,8\%, specifičnost 90,5\%, pozitivna $88,2 \%$ i negativna predikativna vrednost $95,0 \%$ i RCA senzitivnost $100 \%$, specifičnost 98,5\%, pozitivna 90,0\% i negativna predikativna vrednost 100\%.(120)

Većina studija je posmatrala visoko selektovane bolesnike često starosne dobi do 50 godina, bez prethodnih epizoda ishemijske bolesti srca i bez evenulatno sprovedenih revaskularizacionih procedura. Pojedine su bile isključive i u pogledu postojanja faktora rizika za KVB, posebno onih koji sa povećanom predispozicijom ka većem procentu kalcijumskih depozita, kao što su Diabetes mellitus-a, hronična bubrežna insfucijencija i hiperlipidemia. Iako su ovi rezultati delom posledica i niske prevalence koronarnih stenoza u većini studija, 
svakako ukazuju na pouzdanost MSCT koronarografije pri isključenju postojanja signifikantne koronarne bolesti.

Maijboon i saradnici su sproveli multicentričnu, prospektivnu studiju, koja je obuhvatila 433 simptomatska bolesnika sa tipičnim ili atipičnim anginoznim tegobama. Bolesnici uključeni u studiju su bili u starosnoj dobi između 50 i 70 godina, dok su oni sa prethodno sprovedenom revaskularizacijom miokarda bili isključeni. Prevalenca postojanja najmanje jednosudovne bolesti je bila 68,0\%, i analiza je obuhvatila praktično sve segmente koronarnih arterija, čak i one lošije vidljivosti. Senzitivnost pri detekciji bolesnika sa značajnom koronarnom bolesti je bila 99,0\%, specifičnost $64,0 \%$, pozitivna $86,0 \%$ i negativna predikativna vrednost $97,0 \%$.

Analiza dijagnostičke pouzdanosti MSCT koronarografije po pojedinačnim arterijama je ukazala da je za LAD senzitivnost iznosila 99,0\%, specifičnost $56,0 \%$, pozitivna 57,0\% i negativna predikativna vrednost 99,0\%, dok je za RCA senzitivnost bila 94,0\%, specifičnost 77,0\%, pozitivna 73,0\% i negativna predikativna vrednost 96,0\% (121).

Naša studija je bila prospektivnog karaktera i posmatrala bolesnike prosečno

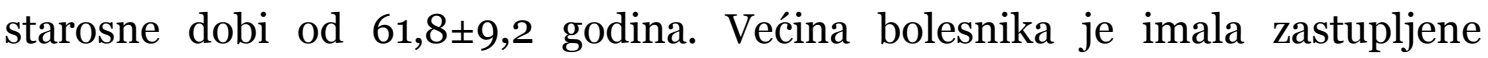
višestruke faktore rizika za kardiovaskularne bolesti. U ovu heterogenu populaciju su bili uključeni i bolesnici sa prethodno sprovedenom revaskularizacijom miokarda putem PCI ili koronarnom hirurgijom.

Statistička analiza podataka MSCT koronarografije, pomoću ROC krive je ukazala na senzitivnost $80,0 \%$ i specifičnost $64,4 \%$ pri detekciji opstruktivnih promena na LAD, uzimajući stenoze dijametra 72,5\% kao graničnu vrednost (Slika br.14). Analiza ROC krive MSCT koronarografije za RCA pri detekciji opstruktivnih promena na RCA sa graničnim stenozama dijametra 67,5\% je imala slične vrednosti senzitivnosti od $86 \%$ i specifčnosti od 63,6\%. (Slika br.18) Procena dijagnostičke vrednosti tehnika standardnim jednačinama je ukazala da je neinvazivna koronarografija pri detekciji stenoza dijametra većeg od 70\% na LAD imala senzitivnost $88,0 \%$, specifičnost $57,6 \%$, pozitivnu $46,8 \%$ i 
negativnu predikativnu vrednost $91,2 \%$, a pouzdanost $66,7 \%$, a na RCA je imala senzitivnost $86,2 \%$, specifičnost $69,1 \%$, pozitivnu $59,5 \%$ i negativnu predikativnu vrednost 90,5\% i pouzdanost 75,0\%.

U poređenju sa rezultatima prethodnih autora, izuzev Maijboon-a i saradnika imali smo nešto niže vrednosti specifičnosti i pozitivne predikativne vrednosti što ukazuje na čestu precenjenost aterosklerotskih lezija putem MSCT koronarografije.

Naša studija je obuhvatila stariju populaciju bolesnika sa višestrukim faktorima rizika za kardiovaskularne bolesti, te su najverovatnije imali i više kalcijumskih depozita, koji su otežavali analizu svih segmenata koronarnih arterija. Prethodno je pokazano da blješteći efekti kalcijuma dovode do otežane vizuelizacije lumena koronarne arterije, kao i smanjenja specifičnosti i pozitivne predikativne vrednosti. Precizno gradiranje težine stenoza često nije moguće usled otežane procene i njene lokalizacije, jer sami blješteći efekti kalcijumskih depozita uglavnom ne odgovaraju i mestu najizrazitijih aterosklerotskih promena (122).

Tokom tumačenja naših snimaka, analizirani su svi segmenti koronarnih arterija, čak i u slučaju prikaza slabijeg kvaliteta. Procenat segmenata koji je isključivan iz analize i krajnjeg zaključka o dijagnostičkoj pouzdanosti tehnike, zbog loše interpretabilnosti, u svim drugim studijama izuzev Meijboon-a i saradnika (121) je bio i do $12 \%$. U našoj analizi svi neinterpretabilni segmenti su tumačeni kao značajno izmenjeni, jer u svakodnevnom kardiološkom radu, najčešće svi bolesnici čak i sa suspektnim promenama na MSCT koronarografiji bivaju upućeni na invazivnu koronarografiju, te na ovaj način procenjena dijagnostička pouzdanost je realan reprezent kliničke prakse.

Rezultati našeg istraživanja shodno visokoj negativnoj predikativnoj vrednosti ukazuju da je koronarna angiografija putem "64-slajsne" kompjuterizovane koronarografije pouzdana dijagnostička procedura za isključenje postojanja opstruktivnih promena, dijametra stenoze većeg od 70\% na LAD i RCA, u heterogenoj kardiološkoj populaciji sa tegobama karaktera stabilne pektoralne 
angine. Niske vrednosti specifičnosti i pozitivne predikativne vrednosti indirektno su pokazatelji precenjenosti aterosklerotskih lezija putem neinvazivne koronarografije, usled čega zahtevaju dodatnu evaluaciju pre odluke o daljem ispitivanju i lečenju. Naša zapažanja se podudaraju sa zaključcima i prethodnih istraživanja $(62-64,82-84,121)$.

Koronarna angiografija putem "64-slajsne" kompjuterizovane tomografije ima svoja značajna ograničenja, prostorna rezolucija je oko 2 puta manja u poređenju sa invazivnom korornarografijom, a vremenska rezolucija oko 20 puta, što i sa upotrebom elektrokardiografskog usmeravanja se teško može prevazići, posebno kod bolesnika sa aritmijama. Dodatno smanjenju rezolucije doprinosi i brza pokretljivost koronarnih arterija, posebno RCA. Sva ova ograničenja onemogućavaju precizno kvantifikovanje težine stenoze koronarne arterije, a u slučaju većih kalcifikacija najčešće dovode do precenjenosti težine stenoza.

Angiografski posmatrano koronarne arterije su promera nekoliko milimetara, tako i razlika između dijametra intermedijarnih (50-70\%) i teških stenoza ( $\geq 70 \%)$ je u suštini nekoliko desetina milimetara, te sama konvencionalna angiografija, koja je značajno bolje prostorne i temporalne rezolucije nemože uvek sprovesti u potpunosti i pouzdanu gradaciju težine lezije. Svakako da rezultati neinvazivne koronarografije, koji se odnose na analizu koronarnih arterija različitog dijametra ukazuju da je dijagnostička pouzdanost bila najveća na koronarnim arterijama najvećeg promera (121) (Tabela br.9). 
Tabela br. 9. Analiza uticaja dijametra koronarne arterije na dijagnostičku pouzdanost 64 "slajsne" MSCT koronarografije /segmentna analiza, CI 95\%/

\begin{tabular}{|c|c|c|c|c|}
\hline $\begin{array}{l}\text { Segementna } \\
\text { analiza } \\
\text { Diametar, } \\
\text { mm }\end{array}$ & Senzitivnost(\%) & Specifičnost(\%) & $\begin{array}{l}\text { Pozitivna } \\
\text { predikativna } \\
\text { vrednost(\%) }\end{array}$ & $\begin{array}{l}\text { Negativna } \\
\text { predikativna } \\
\text { vrednost(\%) }\end{array}$ \\
\hline$\geq 2$ & $89(86-92)$ & $90(88-91)$ & $49(45-53)$ & $99(98-99)$ \\
\hline $1,5-2$ & $77(54-100)$ & $91(88-94)$ & $20(10-32)$ & $99(98-100)$ \\
\hline$<\mathbf{1 , 5}$ & $45(10-75)$ & $96(94-98)$ & $29(7-58)$ & $99(96-99)$ \\
\hline
\end{tabular}

Obzirom, da je MSCT koronarografija neadekvatan prediktor funkcionalne značajnosti aterosklerotskih lezija (124), nekoliko komparabilnih studija je sprovedeno i sa nuklearnom perfuzionom scintigrafijom miokarda je u cilju procene stvarne hemodinamske značajnosti aterosklerotskih lezija detektovanih prethodno putem MSCT koronarografije.

Izveštaji su ukazali na visok stepen komplementarnosti između 2 tehnike kada su nalazi MSCT koronarografije bili u referetnim granicama. Odnosno većina bolesnika sa normalnim nalazima MSCT koronarografije nije imala detektovane ispade u perfuziji putem SPECT-a, što je u saglasnosti sa visokom negativnom predikativnom vrednošću MSCT koronarografije, koja ukazuje na malu verovatnoću postojanja koronarne bolesti kod ove grupe bolesnika (Slika br.22, A). Bolesnici sa normalnim nalazom MSCT koronarografije i SPECT-a sa sigrunošću ne zahtevaju dalju evaluaciju (124-126). Značajno manji stepen podudarnosti sa nalazima SPECT-a je postojao u grupi bolesnika, koji su putem MSCT koronarografije imali detektovane značajne stenoze (Slika br.22, B). (124126). Hacker i saradnici su prezentovali nisku pozitivnu predikativnu vrednost MSCT koronarografije od 32\% do 60\% pri detekciji ishemije putem SPECT-a (126). Slična zapažanja su uočena i u većoj studiji sa bolesnicima sa intermedijarnom verovatnoćom za postojanje koronarne okluzivne bolesti, samo polovina bolesnika sa detektovanim stenozama na MSCT koronarografiji 
je imala i ishemiju putem SPECT-a (126). Rezultati istraživanja ukazuju da će samo opstruktivne lezije na MSCT koronarografiji biti povezane i sa ispadima perfuzije, te da procenat stenoze na neinvazivnoj koronarografiji nije prediktor ishemije, mada i drugi bitni činioci kao sama struktura plaka i funkcija endotela nisu razmatrani. S druge strane bolesnici koji su imali uredne nalaze SPECT-a, na osnovu nalaza MSCT koronarografije mogu biti podeljeni u grupu pacijenata sa normalnim koronarnim arterijama $\mathrm{i}$ one sa aterosklerozom bez hemodinamskog značaja, ali koja će zahtevati intezivnu medikamentoznu terapiju (127)

Neinvazivna koronarografija i SPECT miokarda iako pružaju komplementarne informacije, koje omogućavaju sinergističku morfološku i funkcionalnu procenu koronarne bolesti visoka doza zračenja kojoj bi bolesnici bili izloženi (oko 41 mSv) ograničava njihovu zajedničku rutinsku primenu u kliničkoj praksi.

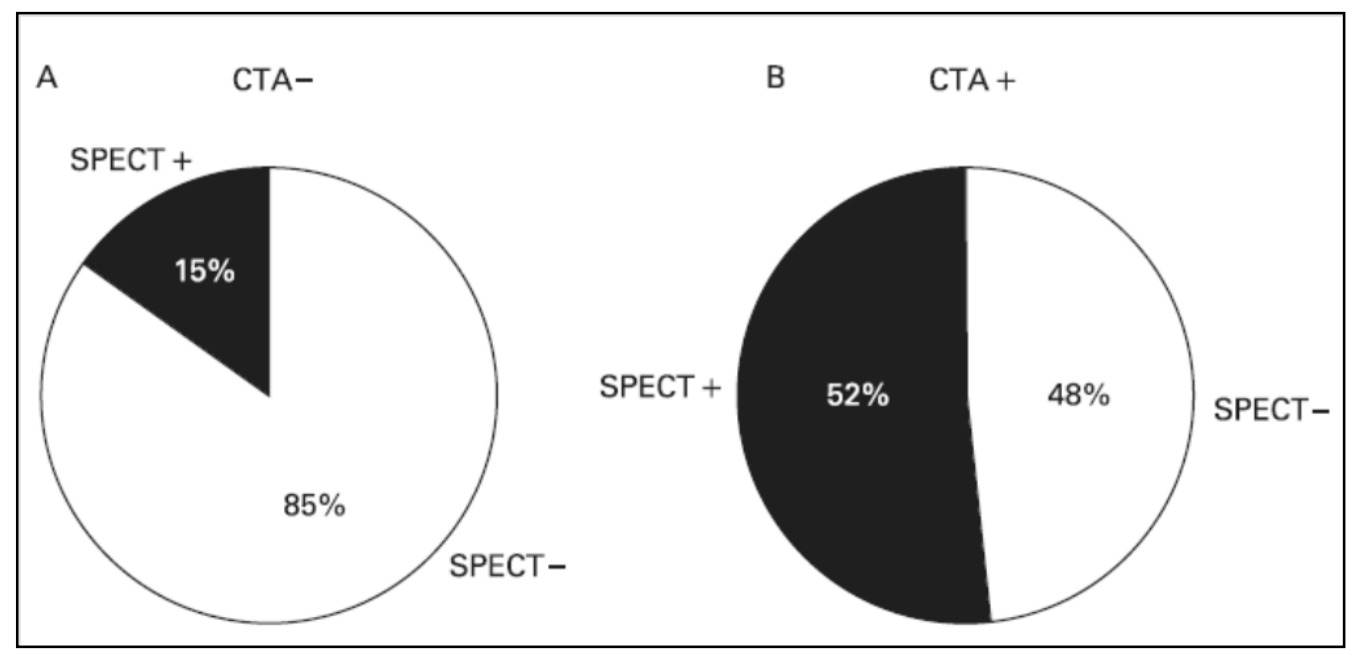

Slika br. 2o. Procenat pozitivnih SPECT nalaza a) kod bolesnika sa normalnim nalazom MSCT koronarografije; b) i kod bolesnika sa detektovanim značajnim stenozama putem MSCT koronarografije (Schuijf D J and Bax J J. CT angiography: an alternative to nuclear perfusion imaging? Heart 2008;94;2 


\subsection{Dijagnostička pouzdanost koronarne rezerve protoka (CFR-a) određene putem Transtorakalne Doppler ehokardiografije pri detekciji koronarne okluzivne bolesti}

Konvencionalna koronarografija, kao i koronarografija putem multislajsne kompjuterizovane tomografije nam omogućavaju uvid $\mathrm{u}$ morfološke karakteristike koronarne cirkulacije, koje su često nedovoljne za preciznu procenu aterosklerotskih lezija posebno intermedijarnog stepena.

Transtorakalna Doppler ehokardiografska procena koronarne rezerve protoka (CFR) je tokom poslednjih nekoliko godina, zahvaljujući unapređenju metodologije i tehnološkim dostignućima, postala značajna neinvazivna dijagnostička procedura u proceni funkcionalnih karakteristika epikardijalne koronarne cirkulacije, kao i poremećaja na nivou mikrocirkulacije.

Prethodno sprovedena istraživanja su ukazala da je granična vrednost $\mathrm{CFR}<2$ imala značajnu dijagnostičku vrednost pri predikciji signifkantih stenoza na epikardijalnim koronarnim arterijama $\mathrm{i}$ ishemije u regionu koji vaskularizuje $(18,19,21,29,30,46)$. CFR u odsustvu značajnih lezija na koronarnim arterijama je značajan parametar i u evaluaciji mirkocirkulacije naročito kod bolesnika starije životne dobi, hipertenzije, Diabetesa, hiperlipidemije, hipertrofije leve komore (36-39). Poremećaji i na nivou mikrocirkulacije mogu rezultovati sniženim vrednostima CFR-a Smatra se da hemodinamski signfikantne stenoze ipak dovode do mnogo značajnije proksimalne rezistencije u odnosu na obolenja mikrocirkulacije, te da vrednosti CFR $<2$ i kod bolesnika sa multiplim faktorima rizika i dalje imaju značajnu dijagnostičku pouzdanost u detekciji značajnih koronarnih lezija (33).

Hosumi i saradnici (29) su među prvim autorima, poredili vrednosti CFR-a procenjenog putem transtorakalne Doppler ehokardiografije sa rezultatima 
invazivne koronarografije, vrednosti $\mathrm{CFR}<2$ su imale senzitivnost 92\%, specifičnost $86 \%$, pozitivnu $79 \%$ i negativnu predikativnu vrednost $95 \%$ pri detekciji signifikantih lezija na LAD (dijametra $270 \%$ ). Važno je naglasiti da je posmatrana visoko selektovana grupa pacijenata, koji prethodno nisu imali arterijsku hipertenziju, Diabetes mellitus, kao i prethodne koronarne dogođaje.

Potom Caiati i saradnici (21) objavljuju podatke prospektivne studije sa prethodno ne selektovanom populacijom, u kojoj je 37,5\% bolesnika prethodno prebolovalo AIM. Vrednost CFR $<2$ je imala senzitivnost $86 \%$, specifičnost $90 \%$ pri detekciji značajnih stenoza na LAD sa visokim stepenom korelacije CFR -a sa invazivnim merenjima FFR -a putem Intrakoronarnog Doppler katetera za procenu protoka $\mathrm{r}=0,88$.

Watanabe i saradnici (25) u svom prospektivnom istraživanju su procenjivali značaj CFR-a putem TTDE u detekciji stenoza dijametra $\geq 75 \%$ na RCA, $u$ selektovanoj grupi bolesnika, koja nije imala zastupljene parameter, koji bi uticali na poremećaje i na nivou mirkocirkulacije. Vrednosti CFR $<2$ su imale senzitivnost $88 \%$, specifičnost $91 \%$, pozitivnu $82 \%$ i negativnu predikativnu vrednost $93 \%$ pri detekciji signifikantih lezija na RCA, sa visokim stepenom korelacije sa invazivnim vrednostima FFR -a putem Intrakoronarnog Doppler katetera za procenu protoka $\mathrm{r}=0,98$.

Voci i saradnici (13) su ispitivali značaj TTDE procenjenog CFR-a u detekciji stenoza dijametra $\geq 70 \%$ na LAD i RCA, kod 81 bolesnika i prezentovali su afirmativne podatke CFR-a za LAD: senzitivnost $89 \%$, specifičnost $100 \%$, dijagnostička pouzdanost $95 \%$ i za RCA: senzitivnost $89 \%$, specifičnost $96 \%$, dijagnostička pouzdanost $93 \%$.

Studija Matsumure i saradnika (33) je sprovedena na najvećem broju ispitanika 138 i za razliku od većine drugih ispitivanja posmatrala bolesnike sa višestrukim faktorima rizika za kardiovskularne bolesti i dokazanim uticajem na patofiziologiju i mikrocirkulacije. Prezentovano je da su vrednosti CFR $<2$ su imale senzitivnost 90\%, specifičnost 93\%, pozitivnu $77 \%$ i negativnu 
predikativnu vrednost $97 \%$ pri detekciji signifikantih lezija na LAD. Svakako da su vrednosti CFR-a bile delom pod uticajem i mikrocirkulacije usled hipertenzije, Diabetesa, hiperlipidemije i pušenja, ali multifaktorijalna logistička analiza je ukazala da su vrednosti CFR bile pod najvećim uticajem dijametra stenoza detektovanih invazivnom koronarografijom $\mathrm{p}<0,0001 \mathrm{i}$ diabetes mellitus-a p<0,0291, ali je uticaj dijametra stenoza određenih invazivnom koronarografijom bio najsnažniji predikativni faktor vrednosti CFR-a.

Rezultati naših istraživanja su u saglasnosti sa rezultatima prethodnih studija i ukazuju da je transtorakalna Doppler ehokardiografska procena koronarne rezerve protoka pouzdana neinvazivna dijagnostička tehnika za detekciju hemodinamski značajnih stenoza obe posmatrane koronarne arterije. CFR je bio u snažnoj korelaciji sa strukturnim promenama detektovanim putem invazivne koronarografije i na LAD i RCA. I tokom našeg istraživanja vrednosti $\mathrm{CFR}<2,02$ putem ROC krivi su imale visoku dijagnostičku pouzdanost pri detekciji opstruktivnih promena na LAD, senzitivnost $88 \%$ i specifičnost $80 \%$.(Slika br.14) i na RCA senzitivnost 76,9\% i specifičnosti 68,6\%.(Slika br.19)

Analiza dijagnostičkih parametara standarnim jednačinama je ukazala da je TTDE procena CFR-a na LAD je imala senzitivnost 92,0\%, specifičnost 90,0\%, pozitivnu $82,1 \%$ i negativnu predikativnu vrednost $95,74 \%$, a pouzdanost $97,3 \%$ i na RCA senzitivnost $76,92 \%$, specifičnost $85,29 \%$, pozitivnu $80,00 \%$, negativnu predikativnu vrednost $82,86 \%$, i pouzdanost $81,67 \%$.

Nešto niže vrednosti senzitivnosti i specifičnosti CFR-a za RCA bi se delom mogle objasniti time da je i sama "feasibilty" tj. izvodljivost tehnike za RCA niža, usled njene brže pokretljivosti i manjeg promera same arterije posebno kod onih bolesnika, kod kojih je dominantna vaskularizacija postero inferornih regiona od strane arterije cirkumflekse tkz. levostrana dominacija, te je sama PDA kod tih pacijenata značajno manjeg promera.

Za razliku od većine prethodnih, naši rezultati istraživanja su reprezent rada u svakodnevnoj kliničkoj praksi, gde većina bolesnika poseduje višestruke faktore 
rizika za kardiovaskularne dogođaje i komorbiditet sa značajnim uticajem i na patofiziologiju mirkocirkulacije. Obzirom, na izvestan uticaj i funkcionalnih karakteristika mikrocirkulacije na vrednosti CFR-a, naši rezultati indirektno ukazuju da su vrednosti same koronarne rezerve protoka ipak pod značajnijim uticajem aterosklerotskih lezija na epikardijalnim koronarnim arterijama u odnosu na promene na nivou mikrocirkulacije. Većina prethodnih ispitivanja izuzev Matsumure i saradnika (33) sprovedena je na visoko selektovanoj populaciji bolesnika bez pratećih uticaja komorbiditeta na fiziologiju mikrocirkulacije.

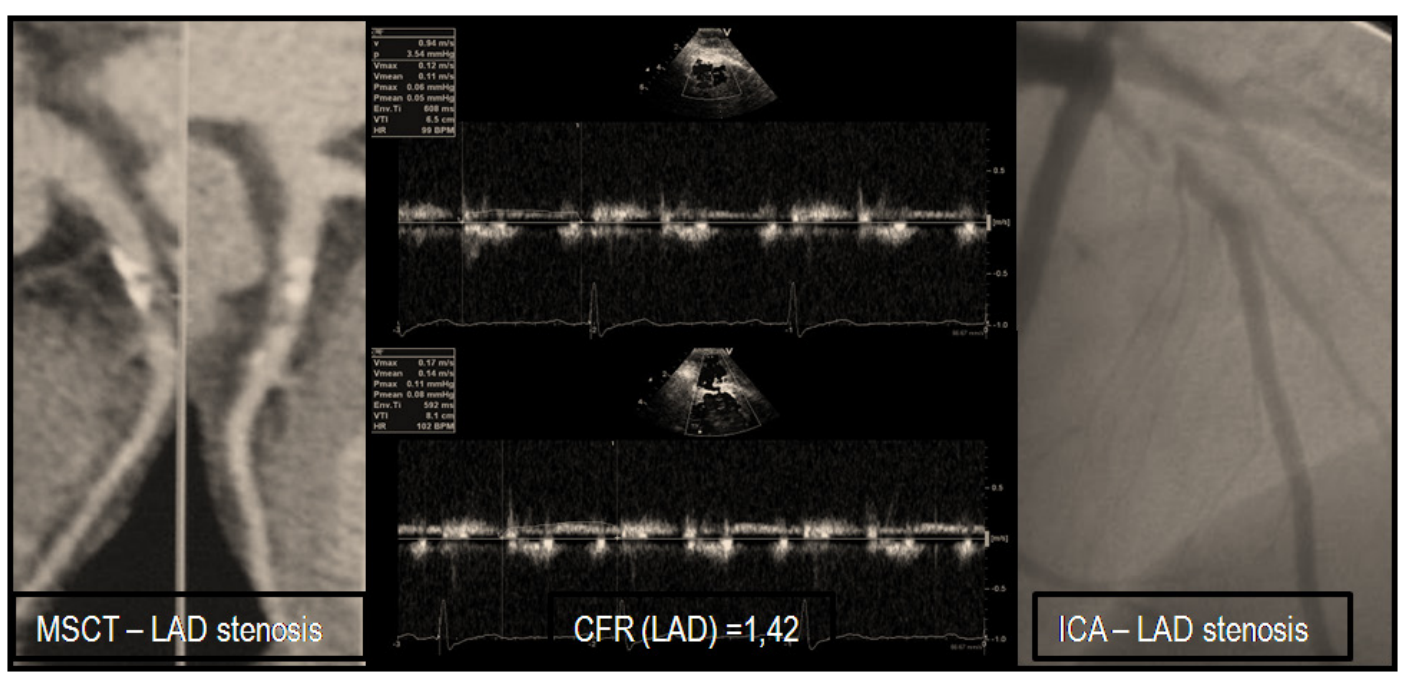

Slika br. 21. Vizuelizacija signifikante stenoze na LAD putem MSCT koronarografije, TTDE CFR-a, invazivne koronarografije 


\subsection{Poređenje vrednosti koronarne rezerve protoka dobijene putem TTDE sa rezultatima MSCT koronarografije i rezultatima koronarne angiografije dobijene invazivnim putem kao referentom tehnikom}

U toku naše studije komparacijom nalaza sve tri tehnike, koji su ukazivali na opstruktivne promene na LAD i RCA, uočena je statistički značajna razlika. Poređenje rezultata između dijagnostičkih procedura pojedinačno je potvrdilo značajnu razliku između neinvazivne koronarografije i TTDE CFR-a, kao i invazivne koronarografije. Statistički značajna razlika nije uočena jedino između nalaza invazivne koronarografije i TTDE-CFR-a, što bi ukazivalo da rezultati koronarne rezerve protoka procenjene putem TTDE najadekvatnije reprezentuju stvarni značaj detektovanih aterosklerotskih lezija. Naši rezultati su u saglasnosti i sa zaključcima prethodnih autora koji su analizirali pouzdanost neinvazivnih nalaza transtorakalne Doppler ehokardiografske procene CFR-a.

Koronarna rezerva protoka predstavlja osnovni parametar procene stvarnog hemodinamskog značaja aterosklerotskih lezija. Invazivna tehnika sa Intrakoronarnim Doppler kateterom za procenu koronarne rezerve protoka tokom konvencionalne koronarografije se smatra referentom metodom tkz. "zlatnim standardom" za procenu funkcionalne značajnosti stenoze, što je do sada potvrđeno kroz nekoliko prethodno sprovedenih studija $(117,118,119)$. Istraživanja koja su poredila vrednosti neinvazivno procenjenih vrednosti CFR-a putem TTDE $\mathrm{i}$ vrednosti dobijene tokom invazivne procene CFR-a Intrakoronarnim Doppler kateterom su ukazale na visok stepen povezanosti između 2 tehnike, koeficijent korelacije u studijama se kretao između o,72 i 0,97 . 
Koronarna angiografija putem 64-"slajsne" kompjuterizovane tomografije je često upotrebljavana neinvazivna dijagnostička procedura, koja omogućava vizuelizaciju početnih aterosklerotskih lezija i depozita kalcijuma, kao i detekciju opstruktivnih aterosklerotskih lezija. Visoka negativna predikativna vrednost, kao njena najznačajnija prednost u odnosu na druge dijagnostičke procedure sa sigurnošću isključuje postojanje signifikantne koronarne bolesti. Vizuelne procene lezija putem MSCT koronarografije najčešće su precenjene, usled blještećih efekata kalcijuma koji stvaraju utisak većih dimenzija plaka.

Rezultati našeg istraživanja korelacionom analizom nalaza na LAD i RCA ukazuju na najznačajniju povezanost između invazivne koronarografije i TTDECFR-a, kao i značajnu povezanost između invazivne i MSCT koronarografije. Najslabiji stepen povezanosti je uočen između MSCT koronarografije i TTDECFR-a (Slika br.12; br.17), što bi indirektno ukazivalo da aterosklerotske lezije detektovane neinvazivnom koronarografijom ne odražavaju i njihov stvarni hemodinamski značaj.

Analiza dijagrama distribucije vrednosti TTDE-CFR-a $\mathrm{u}$ odnosu na nesignifikantne, interemedijarne $\mathrm{i}$ signifikantne stenoze na LAD i RCA detektovane MSCT koronarografijom (Slika br. 13 A; br.18A) pokazuje da većina intermedijarnih i signifikantih lezija na MSCT koronarografiji nije rezultovala sniženjem koronarne rezerve protoka, dok su nalazi ne signifikantih promena uglavnom bili povezani sa očuvanom koronarnom rezervom protoka. Ovi rezultati potvrđuju nalaze i prethodnih autora da su lezije detektovane putem MSCT koronarografije uglavnom u izvesnoj meri precenjene, a da normalni rezultati neinvazivne koronarografije sa sigurnošću isključuju postojanje koronarne bolesti.

Ukoliko analiziramo distribuciju nalaza MSCT koronarografije u odnosu na vrednosti invazivne koronarografije kao referentne tehnike (Slika br. ${ }_{13} \mathrm{C}$; br.18C) također se uočava česta precenjenost lezija detekovanih neinvazivnom koronarografijom na LAD $53,11 \%$ signifikatnih lezija i čak $83,33 \%$ 
interemedijarnih stenoza, a na RCA 42,50\% signifikatnih i 42,86\% intermedijarnih lezija.

Analiza dijagrama distribucije vrednosti TTDE-CFR a u odnosu na nesignifikantne, interemedijarne i signifikantne stenoze LAD i RCA detektovane invazivnom koronarografijom (Slika br. 12B; br.18B) ukazuje na disparitet nalaza kod malog broja pacijenata.

Kod nekoliko pacijenata imali smo očuvane vrednosti koronarne rezerve protoka uz detektovane signifikatne lezije na invazivnoj koronarografiji. Najverovatnije da je postojanje razvijene kolateralne cirkulacije distalno od okluzivne promene uslovilo očuvane vrednosti koronarne rezerve protoka, dok su snižene vrednosti CFR-a kod normalnih koronarnih arterija bile najverovatnje delom i posledica disfunkcije mirkocirkulacije.

Istovetni rezultati su uočeni i komparativnom studijom između MSCT koronarografije i FFRa (129). Nalazi MSCT koronarografije su bili u korelaciji sa invazivnom koronarografijom, ali veliki procenat oko $42 \%$ siginifkantih lezija na MSCT koronarografiji nije rezultovao signifikanim funkcionalnim promenama na FFR -u. Značajno je istaći da je odsustvo promena na MSCT koronarografiji bilo povezano sa normalnim nalazima FFR-a, što potvrđuje da normalni nalazi MSCT koronarografije pouzdano isključuju postojanje značajne koronarne bolesti.

Slični rezultati su prezentovani od strane Meijbooma i saradnika koji su uočili da anatomski detektovane aterosklerotske lezije putem MSCT koronarografije su imale senzitivnost $94 \%$, specifičnost $40 \%$ i dijagnostičku pouzdanost od $49 \%$ u predikciji hemodinamski signifikantih lezija verifokovanih putem FFRa. Najveća diskrepanca nalaza je zapažena pri poceni stenoza intermedijarnog stepena (130).

Komparativne studije između MSCT koronarografije i nuklearne perfuzione scintigrafije su referisale slične rezultate. Oni su ukazivali na nisku korelaciju između anatomske procene neinvazivnom koronarografijom i funkcionalne 
procene perfuzionom scinitgrafijom, samo oko 50\% signifikatnih lezija neinvazivne koronarografije je rezultovalo ishemijskim ispadima na perfuzionim snimcima. Mada je neophodno napomenuti da miokardijalni perfuzioni ispadi ne reprezentuju isključivo poremećaje na nivou epikardijalne koronarne cirkulacije, nego su delom odraz i funkcije mikrovaskularne mreže $(125,126,128)$.

Naši rezultati ukazuju se kod bolesnika sa normalnim nalazom MSCT koronarografije može sa sigurnošću isključiti postojanje koronarne bolesti. Detektovane lezije putem MSCT koronarografije zahtevaju dodatnu funkcionalnu procenu, posebno lezije intermedijarnog i težeg stepena, zbog često otežane pouzdane kvantifikacije aterosklerotskih lezija i visoke stope lažno pozitivnih rezultata, posledično niske specifičnosti i pozitivne predikativne vrednosti ove dijagnostičke tehnike. Tokom sprovedenog istraživanja pokušali smo da determinišemo značaj dodatne procene očuvanosti koronarne rezerve protoka putem transtorakalne Doppler ehokardiografije, kod prethodno detektovanih aterosklerotskih lezija neinvazivnom koronarografijom, u cilju unapređenja njene dijagnostičke pouzdanosti.

Kada su tokom analize podataka kao stvarno značajne lezije razmatrane samo one kod kojih su obe tehnike ukazivale na signifkantne stenoze, imali smo unapređenje specifičnosti, pozitivne predikativne vrednosti i dijagnostičke pozdanosti do 97,33\% za LAD i 90,o0\% za RCA, dok su senzitivnost i negativna predikativna vrednost bile neznatno izmenjene. (Slika br.16 i Slika br.21). Rezultati ukazuju da bi se dodatnom procenom TTDE-CFR-a značajno snizio procenat precenjenih nalaza putem MSCT koronarografije samim tim i lažno pozitivnih rezultata, što bi značajno smanjilo i broj neadekvatno indikovanih invazivnih koronarografija.

Prethodno je samo studija Pizzut-a i saradnika analizirala aditivni dijagnostički značaj TTDE CFR-a kod bolesnika sa prethodno detektovanim promena na MSCT koronarografiji. Oni su u svoje istraživanje uključili 144 bolesnika i za razliku od naše studije koristili su 40- "slajsnu" MSCT koronarografiju i 
analizirali promene samo na LAD. Zapazili su značajno unapređenje dijagnostičke pouzdanosti pri detekciji signifkantih stenoza na LAD kada su zajednički sa nalazima MSCT koronarografije razmatrani i rezultati CFR-a za LAD. Vrednosti TTDE CFR-a za LAD u multivarijantnoj regresionoj analizi su bile najznačajniji prediktor signifikantih stenoza na LAD (131).

Anatomska evaluacija koronarne okluzivne bolesti, čak i sa budućim tehnološkim unapređenjima ima svoja ograničenja u proceni stvarne fiziologije i posledica posmatranih aterosklerotskih lezija. Sinergistička procena anatomskih i funkcionalnih karakteristika će najadekvatnije determinisati bolesnike, koji će najveću korist imati od primene sekundarnih preventivnih mera i medikamentozne terapije (koronarna ateroskleroza sa očuvanom koronarnom rezervom protoka) ili one koji bi trebalo da budu lečeni revaskularizacionim procedurama (koronarna ateroskleroza sa sniženom koronarnom rezervom protoka). Transtrokalna Doppler ehokardiografska procena očuvanosti koronarne rezerve protoka je neinvazivna i visoko reproducibilna dijagnostička procedura za funkcionalnu procenu koronarne okluzivne bolesti, ali sa izvesnim ograničenjima u odnosu na mikrocirkulaciju. Obzirom na izvesna ograničenja neivazivnih testova, svakako da bi u visoko rizičnim subpopulacijama bolesnika sa višestrukim faktorima rizika, ili nalazima MSCT koronarografije, koji ukazuju na suspektne lezije na glavnom stablu leve koronarne arterije ili tešku višesudovnu bolest trebalo sprovesti i invazivnu koronarografiju, bez obzira na prethodne neinvazivne nalaze. 


\subsection{Prognostička vrednost koronarne rezerve protoka određene putem TTDE $u$ odnosu na pojavu neželjenih kardiovaskularnih događaja i daljeg toka bolesti}

Tokom poslednjih nekoliko godina koronarna rezerva protoka se smatra osnovnom determinantom hemodinamskih karakteristika aterosklerotskih lezija. Transtorakalna Doppler ehokardiografska procena je omogućila neinvazivnu procenu koronarne rezerve protoka praktično bez neželjenih dejstava. Do sada je sproveden mali broj studija, koji se bavio prognostičkim značajem koronarne rezerve protoka procenjene putem TTDE.

Rigo i saradnici su prvi referisali o značaju aditivne dijagnostičke vrednosti CFR-a kod bolesnika, koji su imali normalan nalaz Dipiridamol stres ehokardiografije. Bolesnici sa sniženim vrednostima CFR-a su imali značajno lošiju prognozu u toku 24 mesečnog praćenja $(95,96)$.

Potom je sprovedena prospektivna studija praćenja tokom 14 meseci kod bolesnika sa intermedijarnim stenozama na LAD, koji su medikamentozno lečeni, snižene vrednosti koronarne rezerve protoka su bile jedini neovisan prediktor pojave neželjenih kardijalnih događaja (Slika br.22) (132) 


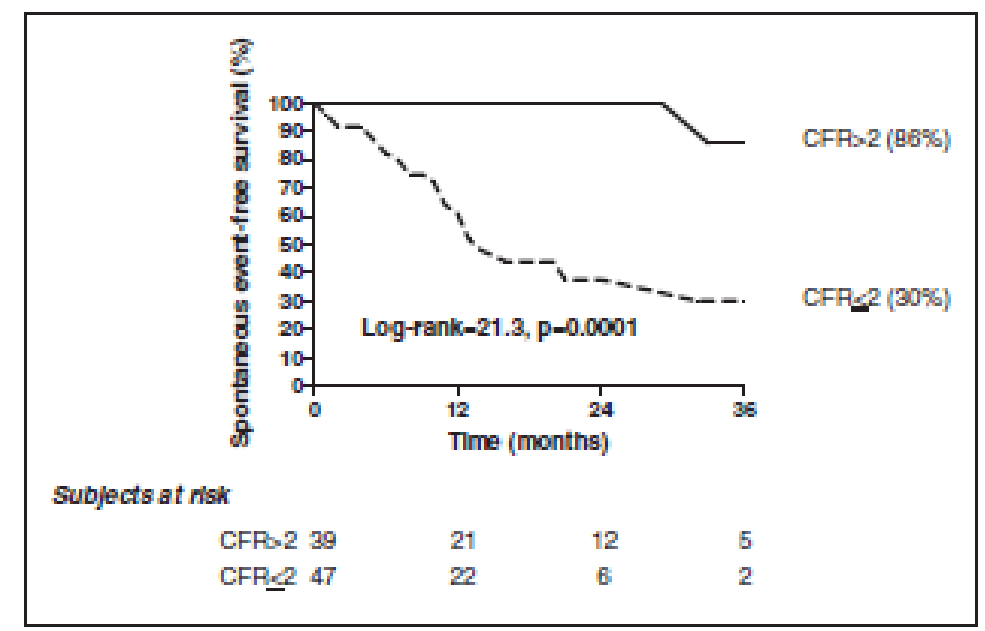

Slika br. 22. Kaplan Meier kriva: pojava neželjenih kardijalnih događaja kod bolesnika grupisanih na osnovu sniženih ili povišenih vrednosti CFR-a tokom Dipridamol stres ehokardiografije.( Rigo F, Sicari R, Gherardi S, et al: Prognostic value of coronary flow reserve in medically treated patients with left anterior descending coronary disease with stenosis $51 \%$ to 75\% in diameter. Am J Cardiol 2007;100:1527)

Najveća do sada sprovedena studija je pratila 280 bolesnika kod kojih je odlučivanje o daljoj revaskularizaciji intermedijarnih stenoza na LAD rukovođeno shodno rezultatima neinvazivno procenjene koronarne rezerve protoka. Bolesnici su lečeni medikamentozno ukoliko su vrednosti CFR bile veće od 2, dok je PCI sa implantacijom stenta sprovedena kod svih sa sniženim vrednostima CFR-a. Monitoring svih posmatranih pacijenata je izvršen tokom 43 meseca i statistički značajna razlika nije uočena $\mathrm{u}$ pogledu mortaliteta $\mathrm{i}$ neželjenih kardijalnih događaja kod obe grupe posmatranih bolesnika (133)

Meimoun i saradici (134) su pratili 110 bolesnika sa intermedijarnim stenozama na LAD i odluka o daljem lečenju je donošena na osnovu vrednosti CFR procenjenog putem TTDE, te je zaključeno da je kod pacijenata sa očuvanom rezervom koronarnog protoka odlaganje 
sprovođenja revaskularizacije bilo povezano sa malim procentom neželjenih kardijalnih događaja.

Rezultati naše studije su u saglasnosti sa zaključcima prethodnih istraživača. Praćenje daljeg toka bolesti kod naših pacijenata tokom šestomesečnog perioda, je pokazalo da su u grupi bolesnika kod kojih smo imali snižene vrednosti CFR-a na LAD i CFR -a na RCA bilo i značajno više bolesnika kod kojih je dalji tok lečenja zahtevao revaskularizaciju miokarda putem PCI ili koronarne hirugije. Multivarijantna regresiona analiza je ukazala da su vrednosti CFR-a na LAD i RCA bili najznačajniji prediktori daljeg toka bolesti i lečenja.

Slični rezultati su prezentovani kod bolesnika u okviru DEFER studije, kod kojih je na osnovu invazivnih merenja FFR-a donošena odluka o daljem vidu lečenja (117). Zaključeno je da bolesnici kod kojih je revaskularizacija sprovedena i pored očuvanih vrednosti FFR-a nisu imali bolju prognozu u odnosu na bolesnike sa očuvanim vrednostima FFR-a koji su medikamentozno lečeni. Rezultati FAME studije (119) na većem broju ispitanika su praktično potvrdili prethodne zaključke. Pacijenti sa višesudovnom koronarom bolešću kod kojih je dalje lečenje planirano na osnovu rezultata FFR-a, imali su značajno bolju prognozu i manje troškove lečenja u odnosu na gupu bolesnika lečenih samo na osnovu morfoloških podataka. Nalazi COURAGE studije (118), ukazuju da je revaskularizacija sprovedena samo na osnovu prethodno dokazane ishemije rezultovala unapređenjem kliničkog toka bolesti. 


\subsection{Ograničenja sprovedene studije}

Mišljenja smo da bi rezultate studije trebalo posmatrati u okviru izvesnih ograničenja tokom njenog sporovođenja. Njihovim eventualnim prevazilaženjem tokom naredenih istraživanja bi se postiglo olakšano tumačenje rezultata, posmatranje ovih bolesnika sa dodatnih aspekata i dobijanje značajnih saznanja u pogledu dijagnostike koronarne bolesti.

- Studija je sprovedena na relativno malom broju ispitanika te bi veće, prospektivne studije značajno unapredile pouzdanost prethodnih analiza.

- Procena dijagnostičke vrednosti TTDE - CFR-a je sprovedena samo na LAD i RCA, zbog nemogućnosti pouzdane vizuelizacije ACX. Budućim tehnološkim unapređenjima koja bi olakšala njeno prikazivanje imali bi smo uvid u celokupnu koronarnu cirkulaciju

- Upotreba kontrastnog sredstva pri vizuelizaciji koronarnih arterija tokom transtorakalne Doppler ehokardiografske procene CFR-a bi značajno unapredila izvodljivost i pouzdanost tehnike.

- Procena nalaza MSCT koronarografije bi eventalno trebala da stratifikuje i posmatra bolesnike i na osnovu kalcijumskog skora. 


\section{ZAKLJUČAK}

- $\mathrm{Na}$ osnovu prethodno iznesenih činjenica zaključujemo da je koronarna angiografija putem 64-"slajsne" kompjuterizovane tomografije je neinvazivna dijagnostička tehnika visoke djagnostičke pouzdanosti pri detekciji opstruktivnih promena na LAD i RCA, sa mogućnošću vizuelizacije celog koronarnog stabla. Visoka negativna predikativna vrednost omogućava pouzdano isključivanje postojanja koronarne bolesti kod bolesnika sa normalnim nalazima neinvazivne koronarografije. Niska pozitivna predikativna vrednost ove tehnike ukazuje na čestu precenjenost aterosklerotskih lezija detektovanih ovom tehnikom, te da je neophodna njihova dodatna evaluacija u cilju preciznije procene njihovog stvarnog značaja.

- Transtorakalna Doppler ehokardiografska procena očuvanosti koronarne rezerve protoka je neinvazivna, lako dostupna, reproducibilna tehnika, visoke pouzdanosti pri detekciji signifikantih koronarnih stenoza. Omogućava procenu stvarnog funkcionalnog značaja aterosklerotskih lezija, sa izvesnim ograničenjima u pogledu mikrocirkulacije.

- Naši rezultati ukazuju da neinvazivna koronarografija i koronarna rezerva protoka procenjena putem TTDE pružaju komplementarne informacije o morfološkim i funkcionalnim karateristikama aterosklerotskih lezija. Dodatna procena putem TTDE-CFR-a hemodinamskog značaja detektovanih stenoza na LAD i RCA intermedijarnog i težeg stepena MSCT 
koronarografijom je rezultovala značajnim unapređenjem dijagnostičke pouzdanosti pri proceni signifikantih promena na koronarnim arterijama. Ovim pristupom bi se značajno smanjio broj nepotrebno sprovedenih invazivnih koronarografija, samim tim i periporceduralnih komplikacija, ekspozicija bolesnika suvišnom zračenju, kao i troškovi lečenja.

- Regresiona analiza je ukazala da su vrednosti CFR-a na LAD i RCA bili značajniji i neovisni prediktori daljeg toka ishemijske bolesti srca i njenog lečenja. 


\section{LITERATURA}

1.Muller JM, Davis MJ, Chilian WM. Integrated regulation of pressure and flow in the coronary microcirculation. Cardiovasc Res 1996;32:668-78.

2.Hoffman JI. Autoregulation and heart rate. Circulation 1990; 82:1880-1.

3.Schindler TH, Nitzsche EU, Olschewski M et al. Pet-measured responses of mbf to cold pressor testing correlate with indices of coronary vasomotion on quantitative coronary angiography. J Nucl Med 2004;45:419-28.

4.Antman Elliott M., Braunwald Eugene. Acute myocardial infarction. In Harrison 's $15^{\text {th }}$ E(ed), Principles of Internal Medicine,Anthony S. Fauci and Dan L. Longo, United States of America, 2002; 1282-1356 (chapter 8, section 23)

5.Thom T, Kannel WB, Silbershatz S et.al Incidence, Prevalence, and Mortality of Cardiovascular Diseases in the United States. Alexander R, Schlant RC, Fuster V, Roberts R (Eds). McGraw Hill, NY, USA (1998).

6.Kannel WB. Prevalence and clinical aspects of unrecognized myocardial infarction and sudden unexpected death. Circulation 1987; II4-II5: 75.

7.Ford ES, Ajani UA, Croft JB et al. Explaining the decrease in U.S. deaths from coronary disease, N. Engl. J. Med 2007: 356(23),2388.

8.Gould KL, Lipscomb K. Effects of coronary stenoses on coronary flow reserve and resistance. Am J Cardiol 1974; 34: 48-55.

9.Voci P, Pizzuto F, Romeo F. Coronary flow: a new asset for the echo lab? Eur Heart J 2004;25:1867. 
10.Meimoun P. and Tribouilloy C. Non-invasive assessment of coronary flow and coronary flow reserve by transthoracic Doppler echocardiography: a magic tool for the real worldEuropean Journal of Echocardiography 2008; 9: 449.

11.Dimitrow Pawel Petkow. Transthoracic Doppler Echocardiography: Noninvasive Diagnostic Window For Coronary Flow Reserve Assessment. Heart Views. 2004;5:55.

12.Rigo F, Bruno M, Ossena $\mathrm{G}$ et al. Transthoracic echocardiographic imaging of coronary arteries: tips, traps, and pitfalls. Cardiovascular Ultrasound 2008, 6:7

13.Voci P, Pizutto F., Mariano E et al. Measurement of coronary flow reserve in the anterior and posterior descending coronary arteries by transthoracic Doppler ultrasound. Am J Cardiol 2002;90:988-91.

14.Sudhir K, MacGregor JS, Barbant SD et al. Assesment of coronary conductance and resistance vessel reactivity in response to nitroglycerin,ergonovine and adenosine: in vivo studies with simultaneous intravscular two-dimensional and Doppler ultrasound. J Am Coll Cardiol 1993;21:1261-8.

15.Lim HE, Shim WJ, Rhee H, et al. Assessment of coronary flow reserve with transthoracic Doppler echocardiography: comparison among adenosine, standard-dose dipyridamole, and highdose dipyridamole. J Am Soc Echocardiogr 2000;13:264-70.

16.Barbato E, Bartunek J, Wyffels E, et al. Effects of intravenous dobutamine on coronary vasomotion in humans. J Am Coll Cardiol 2003;42:1596601.

17.Bartunek J, Wijns W, Heyndrickx GR, et al. Effects of dobutamine on coronary stenosis physiology and morphology: comparison with intracoronary adenosine. Circulation 1999;100:243-9.

18.Diamon M, Watanabe H, Yamagashi H, et al. Physiologic assessment of coronary artery stenosis by coronary flow reserve measurements with transthoracic Doppler echocardiography:comparison with exercise thallium-201 single photon emission computed tomography. J Am Coll Cardiol 2001;37:1310-5. 
19.Meimoun P, Benali T, Sayah S, et al. Evaluation of left anterior descending coronary artery stenosis of intermediate severity using transthoracic coronary flow reserve and dobutamine stress echocardiography. J Am Soc Echocardiogr 2005;12:1233-40.

20.Nohtomi Y, Takeuchi M, Nagasawa K, et al. Simultaneous assessment of wall motion and coronary flow velocity in the left anterior descending coronary artery during dipyridamole stress echocardiography. J Am Soc Echocardiogr 2003;16:457-63.

21.Caiati C, Montaldo C, Zedda N, et al. New non-invasive method for coronary flow reserve assessment: contrast-enhanced transthoracic second harmonic echo Doppler. Circulation 1999;99:771-8.

22.Lethen H, Tries HP, Kersting S, et al. Validation of noninvasive assessment of coronary flow velocity reserve in the right coronary artery: a comparison of transthoracic echocardiographic results with intracoronary Doppler flow wire measurements. Eur Heart J 2003;24: 1567-75.

23.Ueno Y, Nakamura Y, Takashima H, et al. Noninvasive assessment of coronary flow velocity and coronary flow velocity reserve in the right coronary artery by transthoracic Doppler echocardiography comparison with intracoronary Doppler guidewire. J Am Soc Echocardiogr 2002;15:1074-9.

24.Ueno Y, Nakamura Y, Kinoshita M, et al. Noninvasive assessment of significant right coronary artery stenosis based on coronary flow velocity reserve in the right coronary artery by transthoracic Doppler echocardiography. Echocardiography 2003;20:495-501.

25. Watanabe H, Hozumi T, Hirata K, et al. Noninvasive coronary flow velocity reserve measurement in the posterior descending coronary artery for detecting coronary stenosis in the right coronary artery using contrast-enhanced transthoracic Doppler echocardiography. Echocardiography 2004;21:225-33. 
26.Takeuchi M, Ogawa K, Wake R, et al. Measurement of coronary flow velocity reserve in the posterior descending coronary artery by contrastenhanced transthoracic Doppler echocardiography. J Am Soc Echocardiogr 2004;17:21-7.

27.Fujimoto K, Watanabe H, Hozumi T, et al. New noninvasive diagnosis of myocardial ischemia of the left circumflex coronary artery using coronary flow reserve measurement by transthoracic Doppler echocardiography: comparison with thallium-201 single photon emission computed tomography. J Cardiol 2004;43: 109-16.

28.Murata E, Hozumi T, Matsumura Y, et al. Coronary flow velocity reserve measurement in three major coronary arteries using transthoracic Doppler echocardiography. Echocardiography 2006;23:279.

29.Hozumi T, Yoshida K, Ogata Y, et al. Noninvasive assessment of significant left anterior descending coronary artery stenosis by coronary flow velocity reserve with transthoracic color Doppler echocardiography. Circulation. 1998;97:1557.

30.Hozumi T, Yoshida K, Akasaka T, et al. Noninvasive assessment of coronary flow velocity and coronary flow velocity reserve in the left anterior descending coronary artery by Doppler echocardiography: comparison with invasive technique. J Am Coll Cardiol.1998;32:1251-60.

31.Lethen H, Tries HP, Brechtken J, et al.. Comparison of transthoracic Doppler echocardiography to intracoronary Doppler guidewire measurements for assessment of coronary flow reserve in the left anterior descending artery for detection of restenosis after coronary angioplasty. Am J Cardiol 2003;91:412-17.

32.Hildick-Smith DJ, Maryan R, Shapiro LM. Assessment of coronary flow reserve by adenosine transthoracic echocardiography: validation with intracoronary Doppler. J Am Soc Echocardiogr 2002;15:984-90.

33.Matsumara Y, Hozumi T, Watanabe $\mathrm{H}$, et al. Cut-off value of coronary flow velocity reserve by transthoracic Doppler echocardiography for diagnosis of significant left anterior descending artery stenosis in patients with coronary risk factors. Am J Cardiol 2003;92:1389-93. 
34.Ruscazio M, Montisci R, Colonna P, et al. Detection of coronary restenosis after coronary angioplasty by contrast-enhanced transthoracic echocardiographic Doppler and of coronary flow velocity reserve. J Am Coll Cardiol 2002;40:896-903.

35.Pizzuto F, Voci P, Mariano E et al. Assessment of flow velocity reserve by transthoracic Doppler and venous adenosine infusion, before and after left anterior descending coronary stenting. J Am Coll Cardiol 2001;38:155-62.

36. Hirata $\mathrm{K}$, Shimada $\mathrm{K}$, Watanabe $\mathrm{H}$, et al. Modulation of coronary flow velocity reserve by gender, menstrual cycle and hormone replacement therapy. J Am Coll Cardiol 2001;38: 1879-84.

37.Erdogan D, Yildirim I, Ciftci O, et al. Effects of normal blood pressure, prehypertension, and hypertension on coronary microvascular function. Circulation 2007;115:593.

38.Ascione L, De Michele M, Accadia M, et al. Effect of acute hyperhomocysteinemia on coronary flow reserve in healthy adults. J Am Soc Echocardiogr 2004;17:1281.

39.Miyazaki C, Takeuchi M, Yoshitani H, et al. Optimum hypoglycemic therapy can improve coronary flow velocity reserve in diabetic patients: demonstration by transthoracic Doppler echocardiography. Circ J 2003;67:945.

40.Galderisi M, de Simone G, Cicala S, et al. Coronary flow reserve in hypertensive patients with hypercholesterolemia and without coronary heart disease. Am J Hypertens 2007;20:177.

41.Topol EJ, Nissen SE. Our preoccupation with coronary lumenology. The dissociation between clinical and angiographic findings in ischemic heart disease. Circulation 1995;92:2333.

42. Okayama H, Sumimoto T, Hiasa G et al. Assessment of intermediate stenosis in the left anterior descending coronary artery with contrastenhanced transthoracic color-Doppler echocardiography. Coron Artery Dis 2003;14:247-54. 
43.Ferrari M, Schnell B, Werner G et al. Safety of deferring angioplasty in patients with normal coronary flow velocity reserve. J Am Coll Cardiol 1999;33:82.

44.Rigo F, Cortigiani L, Pasanisi E, et al. The additional prognostic value of coronary flow reserve on left anterior descending artery in patients with negative stress echo by wall motion criteria: a transthoracic vasodilator stress echocardiography study. Am Heart J 2006;151:124.

45.Rigo F, Richieri M, Pasanisi E, et al. Usefulness of coronary flow reserve over regional wall motion when added to dual-imaging dipyridamole echocardiography. Am J Cardiol 2003;91:269.

46.Caiati C, Montaldo C, Zedda N, et al. Validation of a non-invasive method (contrast enhanced transthoracic second harmonic echo Doppler) for the evaluation of coronary flow reserve: comparison with intracoronary Doppler flow wire. J Am Coll Cardiol 1999;34:1193.

47.Ueno Y, Nakamura Y, Kinoshita M, et al. Can coronary flow velocity reserve determined by transthoracic Doppler echocardiography predict the recovery of regional left ventricular function in patients with acute myocardial infarction? Heart. 2002; 88:137-141.

48.Colonna P, Cadeddu C, Montisci R, et al. Reduced microvascular and myocardial damage in patients with acute myocardial infarction and preinfarction angina. Am Heart J. 2002; 144:796-803.

49.Chirillo F, Bruni A, Balestra G, et al: Assessment of internal mammary artery and saphenous vein graft patency and flow reserve using transthoracic Doppler echocardiography. Heart. 2001; 86:424-431.

50.Hasdai D, Holmes DR Jr, Higano ST, et al: Prevalence of coronary blood flow reserve abnormalities among patients with nonobstructive coronary artery disease and chest pain. Mayo Clin Proc. 1998; 73:1133

51.Maret E, Engvall J, Nylander E, et al. Feasibility and diagnostic power of transthoracic coronary Doppler for coronary flow velocity reserve in patients referred for myocardial perfusion imaging. Cardiovascular Ultrasound 2008; 6:12 
52.Grondin CM, Dyrda I, Pasternac A, et al. Discrepancies between cineangiographic and postmortem findings in patients with coronary artery disease and recent myocardial revascularization. Circulation 1974;49:703.

53.Roberts WC, Jones AA. Quantitation of coronary arterial narrowing at necropsy in sudden coronary death: analysis of 31 patients and comparison with 25 control subjects. Am. J. Cardiol. 1979;44:39.

54.Hansing CE. The risk and cost of coronary angiography. II. The risk of coronary angiography in Washington State. JAMA 1979;242:735.

55.Nieman K, Oudkerk M, Rensing BJ, et al. Coronary angiography with multi-slice computed tomography. Lancet 2001;357:599-603.

56.Achenbach S, Giesler T, Ropers D, et al. Detection of coronary artery stenoses by contrast-enhanced, retrospectively electrocardiographicallygated, multislice spiral computed tomography. Circulation 2001;103: 2535-8.

57.Ropers D, Baum U, Pohle K,et al. Detection of coronary artery stenoses with thin-slice multi-detector row spiral computed tomography and multiplanar reconstruction.Circulation2003;107: 664

58.Martuscelli E, Romagnoli A, D'Eliseo A, et al. Accuracy of thin-slice computed tomography in the detection of coronary stenoses. Eur Heart $\mathrm{J}$ 2004;25:1043-8.

59.Aviram G, Finkelstein A, Herz I, et al. Clinical value of 16-slice multidetector CT compared to invasive coronary angiography. Int $\mathrm{J}$ Cardiovasc Intervent. 2005;7:21- 8.

6o.Hoffmann U, Moselewski F, Cury RC, et al. Predictive value of 16-slice multidetector spiral computed tomography to detect significant obstructive coronary artery disease in patients at high risk for coronary disease. Patient versus segment-based analysis. Circulation 2004;110:2638-43.

61.Morgan-Hughes GJ, Roobottom CA, et al. Highly accurate coronary angiography with submillimetre, 16 slice computed tomography. Heart 2005;91:308-13. 
62.Leber AW, Knez A, von Ziegler F, et al. Quantification of obstructive and nonobstructive coronary lesions by 64-slice computed tomography. A comparative study with quantitative coronary angiography and intravascular ultrasound. J Am Coll Cardiol 2005;46:147-54.

63.Ropers D, Rixe J, Anders K, et al. Usefulness of multidetector row computed tomography with $64-0.6 \mathrm{~mm}$ collimation and 330-ms rotation for the noninvasive detection of significant coronary artery stenoses. Am J Cardiol 2006;97:343-8.

64.Fine JJ, Hopkins CB, Ruff N, et al. Comparison of accuracy of 64-slice cardiovascular computed tomography with coronary angiography in patients with suspected coronary artery disease. Am J Cardiol 2006;97:173-4.

65.Cordeiro MA, Miller JM, Schmidt A, et al. Non-invasive half millimetre 32 detector row computed tomography angiography accurately excludes significant stenoses in patients with advanced coronary artery disease and high calcium scores. Heart 2006;92:589.

66.Kondo C, Mori S, Endo M, et al. Real-time volumetric imaging of human heart without electrocardiographic gating by 256-detector row computed tomography: initial experience. J Comput Assist Tomogr 2005;29:6948.

67.Mori S, Kondo C, Suzuki N, et al. Volumetric coronary angiography using the 256-detector row computed tomography scanner: comparison in vivo and in vitro with porcine models. Acta Radiol 2006;47:186.

68.Flohr TG, McCollough $\mathrm{CH}$, Bruder H, et al. First performance evaluation of a dual-source CT (DSCT) system. Eur Radiol 2006;16: 256-68.

69.Achenbach S, Ropers D, Kuettner A, et al. Contrast-enhanced coronary artery visualization by dual-source computed tomography- initial experience. Eur J Radiol 2006;57:331

70.Jakobs TF, Becker CR, Ohnesorge B, et al. Multislice helical CT of the heart with retrospective ECG gating: reduction of radiation exposure by ECG-controlled tube current modulation. Eur Radiol 2002;12:1081. 
71.Halliburton SS, Petersilka M, Schvartzman PR, et al.. Evaluation of left ventricular dysfunction using multiphasic reconstructions of coronary multi-slice computed tomography data in patients with chronic ischemic heart disease: validation against cine magnetic resonance imaging. Int $\mathbf{J}$ Cardiovasc Imaging 2003;19:73.

72.Heuschmid M, Kuettner A, Schroeder S, et al. ECG-gated 16-MDCT of the coronary arteries: assessment of image quality and accuracy in detecting stenoses. AJR Am J Roentgenol 2005;184:1413.

73.Cademartiri F, Runza G, Mollet NR, et al. Impact of intravascular enhancement, heart rate, and calcium score on diagnostic accuracy in multislice computed tomography coronary angiography. Radiol Med (Torino) 2005;110:42-51

74.Herzog C, Arning-Erb M, Zangos S, et al. Multi-detector row CT coronary angiography: influence of reconstruction technique and heart rate on image quality. Radiology 2006;238:75-86

75.Schroeder S, Kopp AF, Kuettner A, et al. Influence of heart rate on vessel visibility in noninvasive coronary angiography using new multislice computed tomography: experience in 94 patients. Clin Imaging 2002;26:106 .

76.Hoffmann $\mathrm{MH}$, Shi H, Manzke R, et al. Noninvasive coronary angiography with 16-detector row CT: effect of heart rate. Radiology 2005;234:86.

77.Kuettner A, Beck T, Drosch T, et al. Image quality and diagnostic accuracy of non-invasive coronary imaging with 16-detector slice spiral computed tomography with $188 \mathrm{~ms}$ temporal resolution. Heart 2005; 91:938-41.

78. Mollet NR, Cademartiri F, Krestin GP, et al. Improved diagnostic accuracy with 16-row multi-slice computed tomography coronarym angiography. J Am Coll Cardiol 2005;45:128.

79.Schuijf JD, Bax JJ, Salm LP, et al. Noninvasive coronary imaging and assessment of left ventricular function using 16-slice computed tomography. Am J Cardiol 2005;95:571. 
8o.Hoffmann MHK, Shi H, Schmitz BL, et al. Noninvasive coronary angiography with multislice computed tomography. JAMA 2005;293:2471.

81.Achenbach S, Ropers D, Pohle FK, et al. Detection of coronary artery stenoses using multi-detector CT with $16 \_0.75 \mathrm{~mm}$ collimation and 375 ms rotation. Eur Heart J 2005;26:1978.

82.Leschka S, Alkadhi H, Plass A, et al. Accuracy of MSCT coronary angiography with 64-slice technology: first experience. Eur Heart J 2005;26:1482.

83.Raff GJ, Gallagher MJ, O'Neill WW, et al. Diagnostic accuracy of noninvasive angiography using 64 -slice spiral computed tomography. $\mathrm{J}$ Am Coll Cardiol 2005;46:552-7.

84.Mollet NR, Cademartiri F, van Mieghem CA, et al. High-resolution spiral computed tomography coronary angiography in patients referred for diagnostic conventional coronary angiography. Circulation 2005; 112:2318 -23.

85.Pundziute G, Schuijf JD, Jukema JW et al. Gender influence on the diagnostic accuracy of 64-slice multislice computed tomography coronary angiography for detection of obstructive coronary artery disease. Heart 2008;94(1):48.

86.Iskandrian AE. Detecting coronary artery disease in left bundle branch block. J. Am. Coll. Cardiol. 2006;48:1935.

87.Rumberger JA, Simons DB, Fitzpatrick LA, et al. Coronary artery calcium area by electron-beam computed tomography and coronary atherosclerotic plaque area. A histopathologic correlative study. Circulation 1995; 92:2157.

88.Baumgart D, Schmermund A, Goerge G, et al. Comparison of electron beam computed tomography with intracoronary ultrasound and coronary angiography for detection of coronary atherosclerosis. J Am Coll Cardiol 1997; 30:57. 
89.Rumberger JA, Sheedy PF 3rd, Breen JF, et al. Coronary calcium, as determined by electron beam computed tomography, and coronary disease on arteriogram. Effect of patient's sex on diagnosis. Circulation 1995; 91:1363.

90.Budoff MJ, Georgiou D, Brody A, et al. Ultrafast computed tomography as a diagnostic modality in the detection of coronary artery disease: a multicenter study. Circulation 1996; 93:898.

91.Glagov S, Weisenberg E, Zarins CK, et al. Compensatory enlargement of human atherosclerotic coronary arteries. N Engl J Med 1987; 316:1371.

92.Agatston AS, Janowitz WR, Hildner FJ, et al Quantification of coronary artery calcium using ultrafast computed tomography. J.Am.Coll.Cardiol1990;.15(4):827.

93.O'Rourke RA, Brundage BH, Froelicher VF, et al. American College of Cardiology/American Heart Association Expert Consensus document on electron-beam computed tomography for the diagnosis and prognosis of coronary artery disease. Circulation 2000; 102:126.

94.Haberl R, Becker A, Leber A, et al. Correlation of coronary calcification and angiographically documented stenoses in patients with suspected coronary artery disease: results of 1,764 patients. J Am Coll Cardiol 2001; $37: 451$.

95.Pletcher MJ, Tice JA, Pignone M, et al. Using the coronary artery calcium score to predict coronary heart disease events: a systematic review and meta-analysis. Arch Intern Med 2004; 164:1285.

96.Berman DS, Wong ND, Gransar H, et al. Relationship between stressinduced myocardial ischemia and atherosclerosis measured by coronary calcium tomography. J Am Coll Cardiol 2004; 44:923.

97.Raggi P, Callister TQ, Cooil B, et al. Identification of patients at increased risk of first unheralded acute myocardial infarction by electron-beam computed tomography. Circulation 2000; 101:850.

98.Nasir K, Michos ED, Blumenthal RS, et al. Detection of high-risk young adults and women by coronary calcium and National Cholesterol Education Program Panel III guidelines. J Am Coll Cardiol 2005; 46:1931. 
99.Budoff MJ, Dowe D, Jollis JG et al. Diagnostic performance of 64multidetector row coronary computed tomographic angiography for evaluation of coronary artery stenosis in individuals without known coronary artery disease: results from the prospective multicenter ACCURACY (Assessment by Coronary Computed Tomographic Angiography of Individuals Undergoing Invasive Coronary Angiography) trial. J. Am. Coll. Cardiol. 2008;52:1724.

100.Meyer TS, Martinoff S, Hadamitzky M, et al. Will A, Kastrati A, Schömig A, Hausleiter J: Improved noninvasive assessment of coronary artery bypass grafts using 64-slice computed tomographic angiography in aunselected patient population. J Am Coll Cardiol 2007;49:946.

101.Gaspar T, Halon DA, Lewis BS,et al. Diagnosis of coronary in-stent restenosis with multi-detector row computed tomography. J Am Coll Cardiol 2005; 46:1573.

102.Halon DA, Gaspar T, Peled N, et al. Assessment of luminal diameter of coronary stents using a novel 40 slice multi-detector CT scanner. Circulation 2004; 110:III-563.

103.Lewis BS, Halon DA: Integrating MDCT into clinical practice - CT scanning shows its metal. J Am Coll Cardiol 2007;49(9):960.

104.Ehara M, Kawai M, Surmely J, et al : Diagnostic accuracy of coronary instent restenosis using 64-slice computed tomography: comparison with invasive coronary angiography. J Am Coll Cardiol 2007;49(9):951.

105. Kitagawa T, Yamamoto H, MD, Ohhashi N, et al. Comprehensive evaluation of noncalcified coronary plaque characteristics detected using 64-slice computed tomography in patients with proven or suspected coronary artery disease. Am Heart J 2007;154:1191.

106.Rubinshtein R, Gaspar T, Halon DA, et al. Prevalence and extent of obstructive coronary artery disease in patients with zero or low calcium score undergoing 64-slice cardiac multidetector computed tomography for evaluation of a chest pain syndrome. Am J Cardiol 2007; 99: 472. 
107.Leber AW, Becker A, Knez A, et al..Accuracy of 64-slice computed tomography to classify and quantify plaque volumes in the proximal coronary system: a comparative study using intravascular ultrasound. J Am Coll Cardiol 2006; 47: 672.

108.Ehara S, Kobayashi Y, Yoshiyama M,et al. Spotty calcification typifies the culprit plaque in patients with acute myocardial infarction: an intravascular ultrasound study. Circulation 2004; 110: 3424.

109.Nikolaou K, Sagmeister S, Knez A, et al. Multidetector-row computed tomography of the coronary arteries: predictive value and quantitative assessment of non-calcified vessel-wall changes. Eur Radiol 2003; 13: 2505-2512.

110.Austen WG, Edwards JE, Frye RL, et al. A reporting system on patients evaluated for coronary artery disease. Report of the Ad Hoc Committee for Grading of Coronary Artery Disease, Council on Cardiovascular Surgery, American Heart Association. Circulation 1975;51:5-40

111.Spaan JAE, Piek JJ, Hoofman JIE, et al. Physiological basis of clinically used coronary hemodynamic indices. Circulation 2006;113:446-55

112.Glagov S, Weisenberg E, Zarins CK, et al. Compensatory enlargement of human coronary arteries. N Engl J Med 1987;316:1371.

113.Schoenhagen P, Ziada KM, Kapadia SR, et al. Extent and direction of arterial remodeling in stable versus unstable coronary syndromes: an intravascular ultrasound study. Circulation 2000;101:598-603

114.Arnestt EN, Isner JM, Redwood CR, et al. Coronary artery narrowing in coronary heart disease: comparison of cineangiographic and necropsy findings. Ann Intern Med 1979;91:350-6.

115. Fischer JJ, Samady H, McPherson JA, et al. Comparison between visual assessment and quantitative angiography versus fractional flow reserve for native coronary narrowings of moderate severity. Am J Cardiol 2002;90:210 
116.Kern J.Morton, and Samady Habib. Current Concepts of Integrated Coronary Physiology in the Catheterization Laboratory J. Am. Coll. Cardiol. 2010;55;173-185.

117.Pijls NHJ, Van Schaardenburgh P, Manoharan G, et al. Percutaneous coronary intervention of functionally non-significant stenoses: 5-year follow-up of the DEFER study. J Am Coll Cardiol 2007;49:2105-11

118.Shaw LJ, Berman DS, Maron DJ, et al., for the COURAGE Investigators. Optimal medical therapy with or without percutaneous coronary intervention to reduce ischemic burden: results from the Clinical Outcomes Utilizing Revascularization and Aggressive Drug Evaluation (COURAGE) trial nuclear substudy. Circulation 2008;117:1283-91.

119.Tonino PAL, DeBruyne B, Pijls NHJ, et al. Fractional flow reserve versus angiography for guiding percutaneous coronary intervention. $\mathrm{N}$ Engl J Med 2009;360:3:213-24

120.Leschka S, Scheffel H, Desbiolles L, et al. Combining dual-source computed tomography coronary angiography and calcium scoring: added value for the assessment of coronary artery disease. Heart 2008;94;1154.

121.Meijboom W.B., Matthijs F. L. Meijs D.L., et al. Diagnostic Accuracy of 64-Slice Computed Tomography Coronary Angiography. J Am Coll Cardiol 2008;52:2135.

122.Wexler L, Brundage B, Crouse J, et al. Coronary artery calcification: pathophysiology, epidemiology, imaging methods, and clinical implications. A statement for health professionals from the American Heart Association. WritingGroup. Circulation 1996;94:1175

123.Poon M. Technology insight: cardiac CT angiography. Nat Clin Pract Cardiovasc Med 2006;3:265.

124.Gaemperli O, Schepis T, Koepfli P, et al. Accuracy of 64-slice CT angiography for the detection of functionally relevant coronary stenoses as assessed with myocardial perfusion SPECT. Eur J Nucl Med Mol Imaging. 2007;34:1162. 
125.Schuijf JD, Wijns W, Jukema JW, et al. Relationship between noninvasive coronary angiography with multi-slice computed tomography and myocardial perfusion imaging. J Am Coll Cardiol 2006;48:2508.

126.Hacker M, Jakobs T, Hack N, et al. Sixty-four slice spiral CT angiography does not predict the functional relevance of coronary artery stenoses in patients with stable angina. Eur J Nucl Med Mol Imaging. 2007;34:4.

127.Schuijf D Joanne and Bax J Jeroen. CT angiography: an alternative to nuclear perfusion imaging? Heart 2008;94;255-257

128.Rispler S, Keidar Z, Ghersin E, et al. Integrated single-photon emission computed tomography and computed tomography coronary angiography for the assessment of hemodynamically significant coronary artery lesions. J Am Coll Cardiol 2007;49:1059.

129.Werkhoven J., Schuijf J., Jukema W et al. Comparison of Non-Invasive Multi-Slice Computed Tomography Coronary Angiography Versus Invasive Coronary Angiography and Fractional Flow Reserve for the Evaluation of Men With Known Coronary Artery Disease. Am J Cardiol 2009;104:65.

130.Meijboom B., Mieghem C, Pelt N, et al. Comprehensive Assessment of Coronary Artery Stenoses. J Am Coll Cardiol 2008;52:636

131.Pizzuto F., Voci P., MDa, Bartolomucci F. et al. Usefulness of Coronary Flow Reserve Measured by Echocardiography to Improve the Identification of Significant Left Anterior Descending Coronary Artery Stenosis Assessed by Multidetector Computed TomographyAm J Cardiol 2009;104:657

132.Rigo F, Sicari R, Gherardi S, et al: Prognostic value of coronary flow reserve in medically treated patients with left anterior descending coronary disease with stenosis $51 \%$ to $75 \%$ in diameter. Am J Cardiol 2007;100:1527 
133.D'Andrea A., Severino S., Mita C.,et al. Clinical Outcome in Patients with Intermediate Stenosis of Left Anterior Descending Coronary Artery after Deferral of Revascularization on the Basis of Noninvasive Coronary Flow Reserve Measurement. Echocardiography, 2009; 26:431.

134.Meimoun P., Benali T., Elmkies F. Et al. Prognostic value of transthoracic coronary flow reserve in medically treated patients with proximal left anterior descending artery stenosis of intermediate severity. European Journal of Echocardiography 2009; 10:127. 


\section{Biografija:}

Mladenović Zorica je rođena 1977 godine u Sarajevu.

Osnovno školovanje je završila za sedam godina pohađajući dva poslednja razreda tokom jedne školske godine i Gimnaziju - prirodno matematički smer sa maksimalnom prosečnom ocenom.

Medicinski fakultet, Univerziteta u Beogradu je završila u periodu od 19942000, sa prosečnom ocenom 9,31. Tokom fakulteta je bila student demonstrator na predmetu Medicinska Fiziologija.

Govori Engleski jezik - Aktivno znanje ( "First Certificate in English", Cambridge University, 1999)

Juna 2005 godine je magistrirala na Medicinskom fakultetu, Univerziteta u Beogradu sa temom"Prognostički značaj detekcije vijabilnosti miokarda kod bolesnika nakon akutnog infarkta " (mentor: prof.dr Dimitra Kalimanovska Oštrić).

Specijalizirala je iz oblasti Interne medicine na Vojno Medicinskoj Akademiji u Beograd-u februara 2006 godine.

Decembra 2006 godine je dobila nagradu za mlade istraživače Evropskog ehokardiografskog društva.

Dodatnu edukaciju iz oblasti stres ehokardiografije i transtorakalne Doppler ehokardiografske procene koronarne rezerve protoka je završila u KC Srbije tokom 2008 i 2009 godine.

Autor više radova na domaćim i stranim kongresima kao i publikacija u domaćim i stranim časopisima

Zaposlena u Klinici za Kardiologiju, Vojno medicinske akademije od februara 2006 godine.

Od školske 2009/2010 godine je dobila naučno zvanje Asistenta katedre za Internu medicinu, Medicinskog fakulteta, Vojno medicinske akademije, u Beogradu. 


\section{Прилог 1.}

\section{Изјава о ауторству}

Потписани-а мр сци Зорица Младеновић

број индекса

\section{Изјављујем}

да је докторска дисертација под насловом

Диајгностички и прогностички значај процене коронарне резерве протока одеређене трансторакаланом Допплер ехокардиографијом код болесника са ураћеном коронарном ангиографијом помоћу компјутеризоване томографије

- резултат сопственог истраживачког рада,

- да предложена дисертација у целини ни у деловима није била предложена за добијање било које дипломе према студијским програмима других високошколских установа,

- да су резултати коректно наведени и

- да нисам кршио/ла ауторска права и користио интелектуалну својину других лица.

\section{Потпис докторанда}

у Београду, $0111 \cdot 212$.

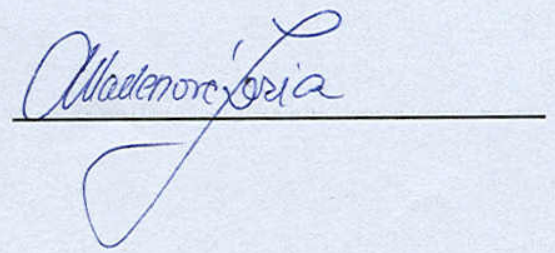


1. Ауторство - Дозвољавате умножавање, дистрибуцију и јавно саопштавање дела, и прераде, ако се наведе име аутора на начин одређен од стране аутора или даваоца лиценце, чак и у комерцијалне сврхе. Ово је најслободнија од свих лиценци.

2. Ауторство - некомерцијално. Дозвољавате умножавање, дистрибуцију и јавно саопштавање дела, и прераде, ако се наведе име аутора на начин одређен од стране аутора или даваоца лиценце. Ова лиценца не дозвољава комерцијалну употребу дела.

3. Ауторство - некомерцијално - без прераде. Дозвољавате умножавање, дистрибуцију и јавно саопштавање дела, без промена, преобликовања или употребе дела у свом делу, ако се наведе име аутора на начин одређен од стране аутора или даваоца лиценце. Ова лиценца не дозвољава комерцијалну употребу дела. У односу на све остале лиценце, овом лиценцом се ограничава највећи обим права коришћења дела.

4. Ауторство - некомерцијално - делити под истим условима. Дозвољавате умножавање, дистрибуцију и јавно саопштавање дела, и прераде, ако се наведе име аутора на начин одређен од стране аутора или даваоца лиценце и ако се прерада дистрибуира под истом или сличном лиценцом. Ова лиценца не дозвољава комерцијалну употребу дела и прерада.

5. Ауторство - без прераде. Дозвољавате умножавање, дистрибуцију и јавно саопштавање дела, без промена, преобликовања или употребе дела у свом делу, ако се наведе име аутора на начин одређен од стране аутора или даваоца лиценце. Ова лиценца дозвољава комерцијалну употребу дела.

6. Ауторство - делити под истим условима. Дозвољавате умножавање, дистрибуцију и јавно саопштавање дела, и прераде, ако се наведе име аутора на начин одређен од стране аутора или даваоца лиценце и ако се прерада дистрибуира под истом или сличном лиценцом. Ова лиценца дозвољава комерцијалну употребу дела и прерада. Слична је софтверским лиценцама, односно лиценцама отвореног кода. 


\section{Прилог 2.}

\section{Изјава о истоветности штампане и електронске верзије докторског рада}

Име и презиме аутора Младеновић Зорица

Број индекса

Студијски програм

Наслов рада Диајгностичи и прогностички значај процене коронарне резерве протока одеређене трансторакаланом Допплер ехокардиографијом код болесника са ураћеном коронарном ангиографијом помоћу компјутеризоване томографрије

Ментордоц. др сци Ана Ђорђевић Дикић

Потписани/а мр.сци Младеновић Зорица

Изјављујем да је штампана верзија мог докторског рада истоветна електронској верзији коју сам предао/ла за објављивање на порталу Дигиталног репозиторијума Универзитета у Београду.

Дозвољавам да се објаве моји лични подаци везани за добијање академског звања доктора наука, као што су име и презиме, година и место рођења и датум одбране рада.

Ови лични подаци могу се објавити на мрежним страницама дигиталне библиотеке, у електронском каталогу и у публикацијама Универзитета у Београду.

Потпис докторанда

у Београду $01.11 \cdot 20 / 2$

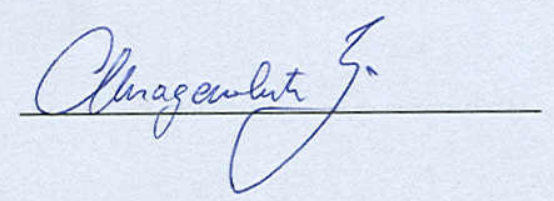




\section{Прилог 3.}

\section{Изјава о коришћењу}

Овлашћујем Универзитетску библиотеку „Светозар Марковић“ да у Дигитални репозиторијум Универзитета у Београду унесе моју докторску дисертацију под насловом:

Диајгностички и прогностички значај процене коронарне резерве протока одерећене трансторакаланом Допплер ехокардиографојом код болесника са урађеном коронарном ангиографијом помоћу компјутеризоване томограффије која је моје ауторско дело.

Дисертацију са свим прилозима предао/ла сам у електронском формату погодном за трајно архивирање.

Моју докторску дисертацију похрањену у Дигитални репозиторијум Универзитета у Београду могу да користе сви који поштују одредбе садржане у одабраном типу лиценце Креативне заједнице (Creative Commons) за коју сам се одлучио/ла.

1. Ауторство

2. Ауторство - некомерцијално

3. Ауторство - некомерцијално - без прераде

4. Ауторство - некомерцијално - делити под истим условима

5. Ауторство - без прераде

6. Ауторство - делити под истим условима

(Молимо да заокружите само једну од шест понуђених лиценци, кратак опис лиценци дат је на полеђини листа).

Потпис докторанда

у Београду, 01.11 .2012

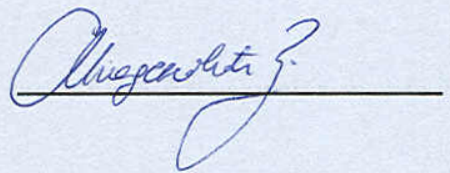

